\title{
WestVirginiaUniversity
}

THE RESEARCH REPOSITORY @ WVU

Graduate Theses, Dissertations, and Problem Reports

2003

\section{Evaluation of the effect of fines on asphalt concrete}

\author{
Carlos Humberto Reyes \\ West Virginia University
}

Follow this and additional works at: https://researchrepository.wvu.edu/etd

\section{Recommended Citation}

Reyes, Carlos Humberto, "Evaluation of the effect of fines on asphalt concrete" (2003). Graduate Theses, Dissertations, and Problem Reports. 1307.

https://researchrepository.wvu.edu/etd/1307

This Thesis is protected by copyright and/or related rights. It has been brought to you by the The Research Repository @ WVU with permission from the rights-holder(s). You are free to use this Thesis in any way that is permitted by the copyright and related rights legislation that applies to your use. For other uses you must obtain permission from the rights-holder(s) directly, unless additional rights are indicated by a Creative Commons license in the record and/ or on the work itself. This Thesis has been accepted for inclusion in WVU Graduate Theses, Dissertations, and Problem Reports collection by an authorized administrator of The Research Repository @ WVU. For more information, please contact researchrepository@mail.wvu.edu. 


\title{
EVALUATION OF THE EFFECT OF FINES ON ASPHALT CONCRETE
}

\author{
Carlos H. Reyes
}

Thesis submitted to the College of Engineering and Mineral Resources at West Virginia University in partial fulfillment of the requirements for the degree of

Master of Science

In

Civil Engineering

\author{
Dr. John P. Zaniewski, Chair \\ Dr. Ronald W. Eck, \\ Dr. Jim French
}

Department of Civil and Environmental Engineering

Morgantown, West Virginia

2003

Keywords: Aggregate, Surface area, Mineral fillers, VMA, Aggregates, Asphalt mix design, Volumetric analysis 


\section{ABSTRACT}

\section{EVALUATION OF THE EFFECT OF FINES ON ASPHALT CONCRETE}

\section{Carlos H. Reyes}

The performance of asphalt surface pavements is directly affected by the quality of the asphalt concrete. Several methods have been developed for determining the quantities of aggregate and asphalt cement used in the asphalt concrete. From the 1940's to the present time, the Marshall method was widely used in the United States. The Hveem method was in favor in some western states. In the 1990's, the SuperPave method was developed during the Strategic Highway Research Program. With the support of the Federal Highway Administration (FHWA), the SuperPave method is becoming widely implemented (Roberts et. al, 1996). The common thread between the Marshall, Hveem and SuperPave methods is the use of volumetric analysis to determine the percentage of asphalt binder needed in an asphalt concrete mixture. The volumetric criteria were developed for the asphalt concrete mixes with natural sand as the fine aggregate. Currently, crushed fine aggregate are used in many mixes. The influence of the differences in the specific surface area between natural sand and the crushed fines has not been evaluated.

This research consists of the evaluation of the surface area of different aggregates used in the state of West Virginia. This factor is important because the amount of asphalt needed to coat the aggregate depends on the specific surface area of the aggregate blend. The specific surface area of the aggregate blend is usually calculated based on the aggregate gradation and surface area factors.

This research proposes a method to obtain accurate specific surface area factors using the Blaine air permeability apparatus. By using the factors obtained, the voids in the mineral aggregate (VMA) and asphalt thickness are calculated. The measured specific surface area of the crushed limestone fines is much greater than the values computed using the traditional approach. This implies that the asphalt concrete made with 100 percent crushed material will have a much thinner asphalt film thickness than was considered adequate when the volumetric mix design criteria were developed. 


\section{ACKNOWLEDGMENT}

The author would like to thank Dr. John Zaniewski, the author's advisor for his guidance and support during the pursuit of the author's Master of Science degree and participate in this research. The author would like to express his gratitude to Dr. Ronald Eck and Dr. Jim French, the author's committee members.

Final thanks are given to Humberto Reyes, Rhaiza de Reyes, Jose Reyes and Maria Del Bufalo, the author's family, for their love and support. You are my source of strength and motivation. 


\section{TABLE OF CONTENTS}

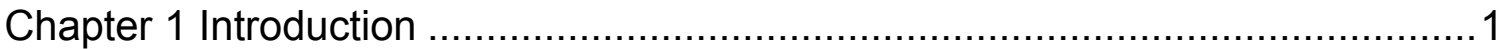

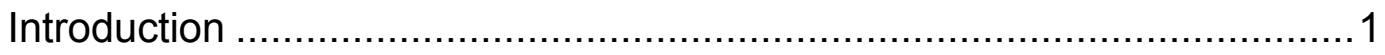

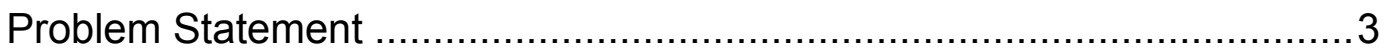

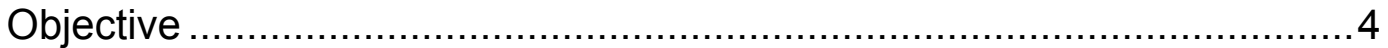

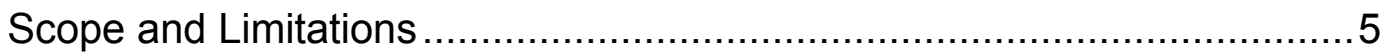

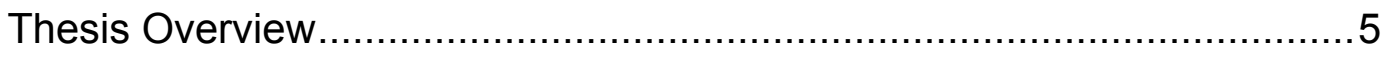

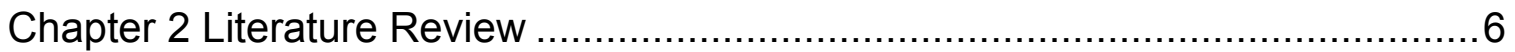

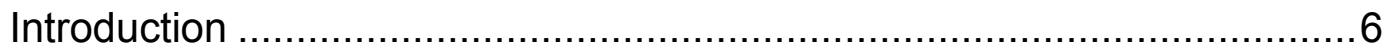

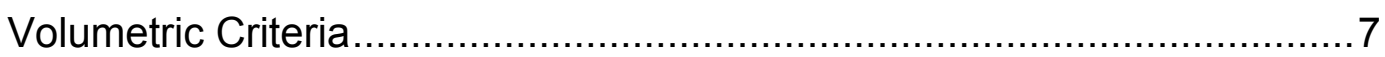

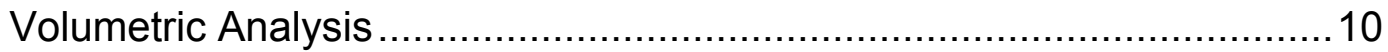

Voids in the Mineral Aggregate ........................................................ 11

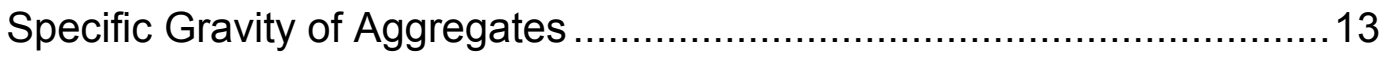

Specifc Gravity for Fine Aggregate .......................................... 14

Specific Gravity for Mineral Filler and Baghouse Fines ................... 16

Estimate Aggregate Effective Specific Gravity .................................... 17

Aggregate Surface Area.............................................................. 18

Methods for Estimating Surface Area ........................................... 18

Methods for Measuring Aggregate Surface Area ............................21

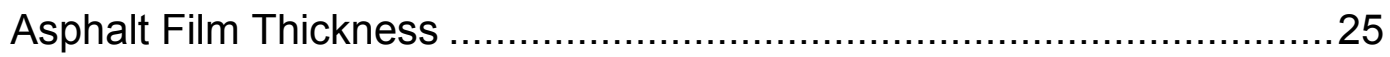

Influence of Mineral Filler on Asphalt Concrete ...................................25

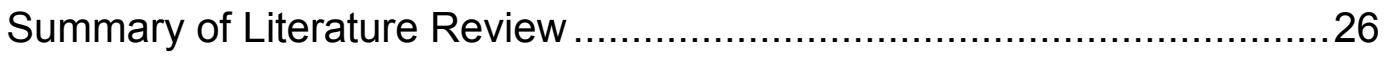

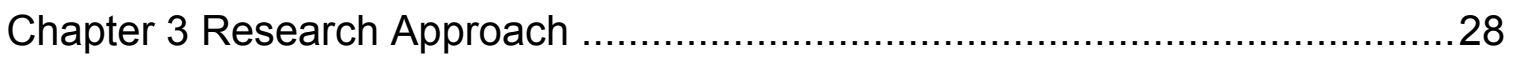

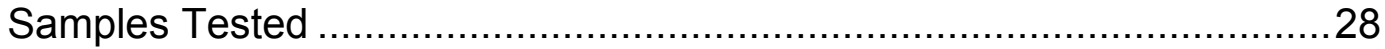

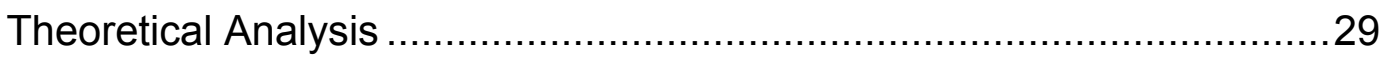

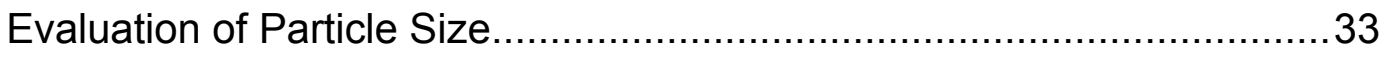

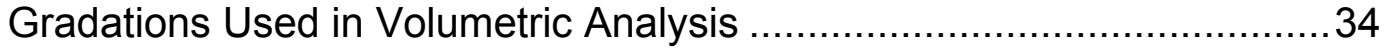

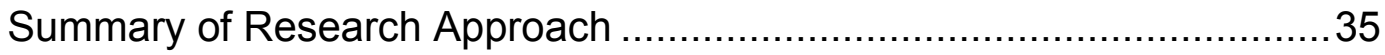

Chapter 4 Data Collection and Analysis....................................................... 38

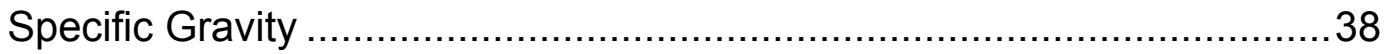

Measured Specific Surface Area ......................................................39 


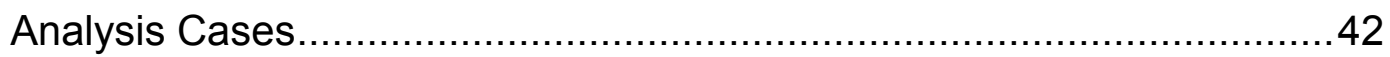

Effect of Aggregate Size on Total Surface Area ................................... 43

Volumetric Parameters................................................................. 4

Effect of Surface Area on Film Thickness .............................................54

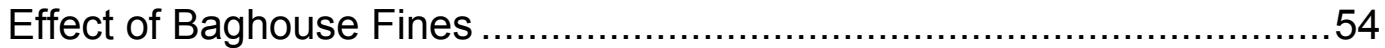

Summary of Data Collection and Analysis ............................................ 55

Chapter 5 Conclusions and Recommendations ..........................................58

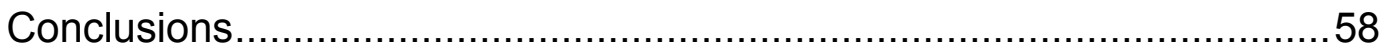

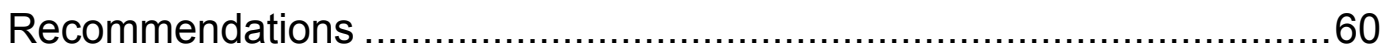

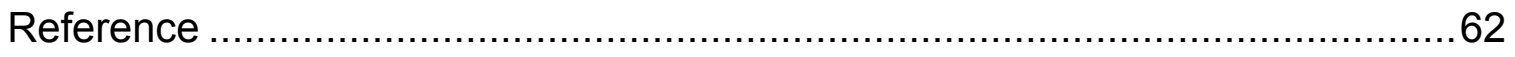

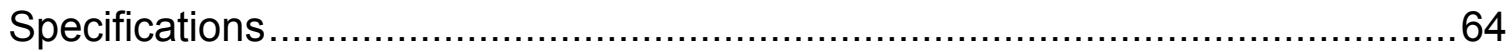

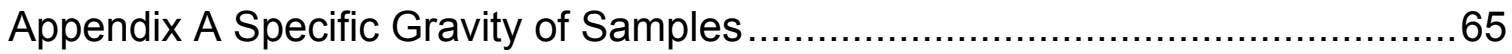

Appendix B Surface Area for the Material Pass $0.15 \mathrm{~mm}$ and Retained on

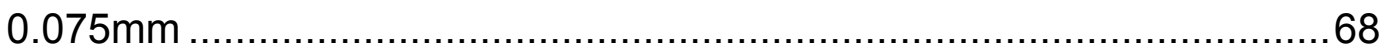

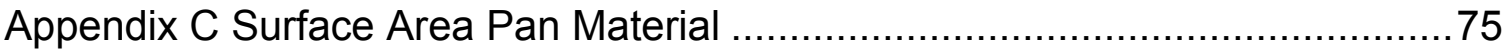

Appendix D Baghouse Fines Specific Surface Areas .....................................82

Appendix E Volumetric Analysis Results ...................................................

\section{LIST OF FIGURES}

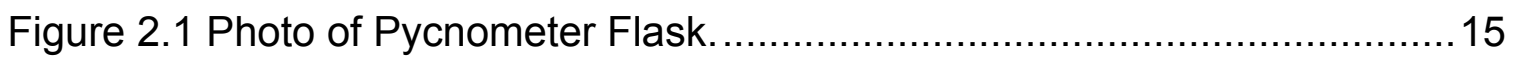

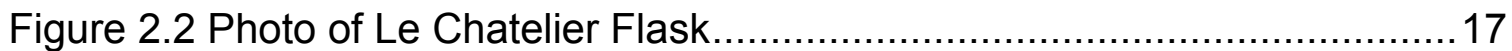

Figure 2.3 Air Permeability Apparatus (Blaine) ……..................................22

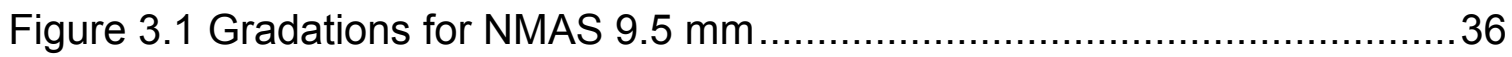

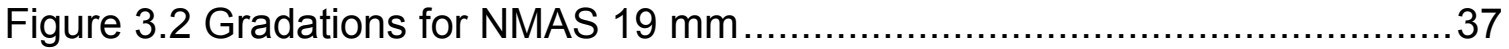

Figure 4.1 Data sheet for Air Permeability Apparatus .......................................40

Figure 4.2 Method for the Calculation of Constant b.....................................41

Figure 4.4 Contribution of Size Material to Surface Area. Gradation \#1 NMAS

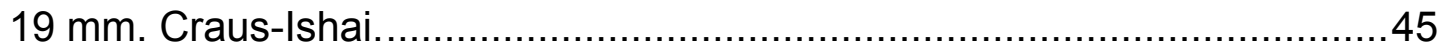

Figure 4.5 Contribution of Size to Material to Surface Area. Gradation \#1 NMAS $19 \mathrm{~mm}$. $\mathrm{D}_{\text {avg }}$ Method. 
Figure 4.6 Contribution of Size to Material to Surface Area. Gradation \#1 MNAS $19 \mathrm{~mm}$. Natural Sand 46

Figure 4.7 Contribution of Size Material to Surface Area Gradation \#1 NMAS $19 \mathrm{~mm}$. Limestone Material. 47

Figure 4.8 VMA Values for 19 mm Mix \#1 8$\mu \mathrm{m}$ Film Thickness........................51

Figure 4.9 VMA Values for 19 mm Mix \#1 2 mm Film Thickness.......................51

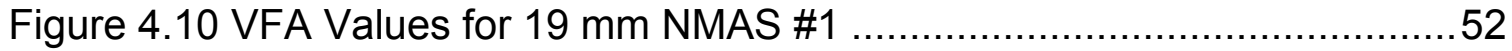

Figure 4.11 VMA for $19 \mathrm{~mm}$ NMAS Gradations $2 \mu \mathrm{m}$ Film Thickness. ...............52

Figure 4.12 VFA for 19 mm NMAS Gradations $2 \mu \mathrm{m}$. Film Thickness ................53

Figure 4.13 F/A for 19 mm NMAS Gradations $2 \mu \mathrm{m}$. Film Thickness .................53

Figure 4.14 MEASURED Surface Area vs. Film Thickness for a 19mm Mix......55

Figure 4.15 Effect of Baghouse Fines Using Gradation \#1 NMAS $19 \mathrm{~mm}$ for a

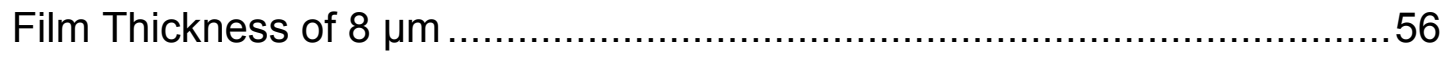

\section{LIST OF TABLES}

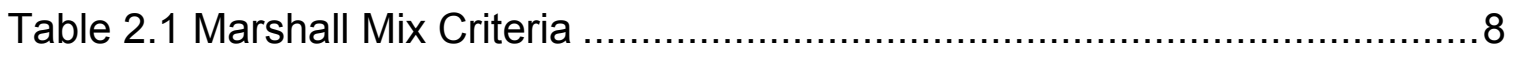

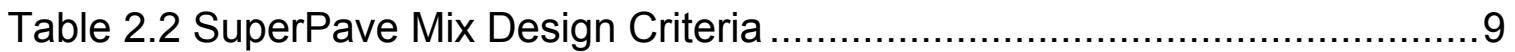

Table 2.3 Surface Area Factors Used by Hveem, Proposed by Edwards...........19

Table 2.4 Craus and Ishai Surface Area Factors ...........................................19

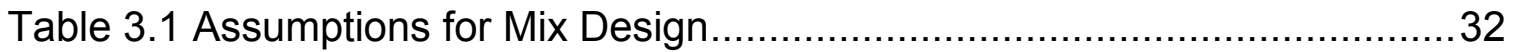

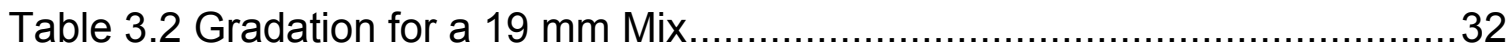

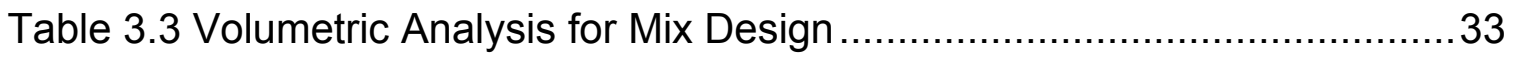

Table 3.4 9.5 mm Mix Designs Gradations for Asphalt Concrete ...................... 36

Table 3.519 mm Mix Designs Gradations for Asphalt Concrete .......................37

Table 4.1 Average Specific Surface Areas for Each Sample ….......................... 38

Table 4.2 Average Specific Surface Area for the Baghouse Fines .....................39

Table 4.3 Surface Area Factors used for the Volumetric Analysis .....................44

Table 4.4 Summary of the Volumetric Properties for $8 \mathrm{~mm}$ Film Thickness,

Edwards-Hveem Surface Area Factors....................................................... 48

Table A.1 Specific gravities of the fine material evaluated ..............................65 
Table A.2 Specific gravities of the baghouse material evaluated 66

Table B.1 APAC sample \# 2 surface area for the material pass $0.15 \mathrm{~mm}$ and retained on $0.075 \mathrm{~mm}$. .68

Table B.2 APAC Sample \#1 surface area for the material pass $0.15 \mathrm{~mm}$ and retained on $0.075 \mathrm{~mm}$.

Table B.3 Summersville limestone surface area for the material pass $0.15 \mathrm{~mm}$ and retained on $0.075 \mathrm{~mm}$. .70

Table B.4 Beaver Boxley (A) surface area for the material pass $0.15 \mathrm{~mm}$ and retained on $0.075 \mathrm{~mm}$. .71

Table B.5 Beaver Boxley (B) surface area for the material pass $0.15 \mathrm{~mm}$ and retained on $0.075 \mathrm{~mm}$. .72

Table B.6 New Enterprise surface area for the material pass $0.15 \mathrm{~mm}$ and retained on $0.075 \mathrm{~mm}$. .73

Table B.7 Natural Sand surface area for the material pass $0.15 \mathrm{~mm}$ and retained on $0.075 \mathrm{~mm}$. 74

Table C.1 Summersville pan material Surface area ...................................... 75

Table C.2 Beaver Boxley Sample (A) pan material surface area ........................76

Table C.3 Beaver Boxley sample (B) pan material surface area .....................77

Table C.4 APAC sample \#1pan material surface area....................................78

Table C.5 APAC Sample \#2 pan material surface area ...................................79

Table C.6 New Enterprise pan material surface area ...................................80

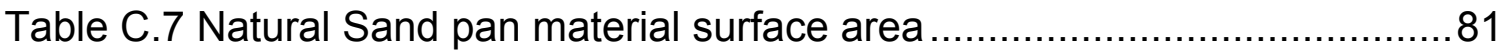

Table D.1 Summersville baghouse fines specific surface area ........................ 82

Table D.2 Gasaway Baghouse fines specific surface area............................. 83

Table D.3 Beaver Boxley Baghouse fine sample (A) specific surface area ........84

Table D.4 Beaver Boxley baghouse fines sample (B) specific surface area .......85

Table D.5 APAC baghouse fine specific surface area ..................................86

Table D.6 J.F. Allen baghouse fines specific surface area ............................ 87

Table D.7 New Enterprise baghouse fines specific surface area....................... 88

Table D.8 W.V. Paving baghouse fines specific surface area...........................89

Table D.9 Tri-State baghouse fines specific surface area................................90 
Table E.1 Volumetric analysis for $9.5 \mathrm{~mm}$ gradation \#1 .................................. 91

Table E.2 Volumetric analysis for $9.5 \mathrm{~mm}$ gradation \#2 .................................92

Table E.3 Volumetric analysis for $9.5 \mathrm{~mm}$ gradation \#3 .................................. 93

Table E.4 Volumetric analysis for $9.5 \mathrm{~mm}$ gradation \#4 ...................................94

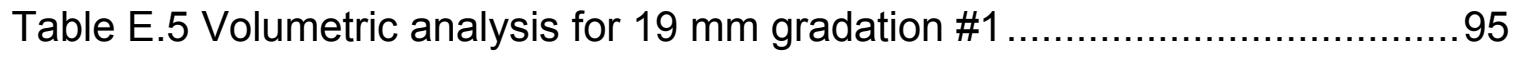

Table E.6 Volumetric analysis for $19 \mathrm{~mm}$ gradation \#2 ................................... 96

Table E.7 Volumetric analysis for $19 \mathrm{~mm}$ gradation \#3 .................................. 97

Table E.8 Volumetric analysis for $19 \mathrm{~mm}$ gradation \#4 ..................................98 


\section{MASTER TABLE OF VARIABLE DEFINITIONS}

b = Constant specifically determined for the test sample.

$b_{s}=0.9$, the appropriate constant for the calibration sample.

$D=$ Density of the mercury at the test temperature $\mathrm{Mg} / \mathrm{m}^{3}$.

$\varepsilon=$ Porosity of the test sample.

$\varepsilon_{\mathrm{s}}=$ Porosity of prepared bed of the calibration sample.

$\mathrm{F}=$ Factor 0.8

$\mathrm{F} / \mathrm{A}=$ Fines to asphalt ratio

$\mathrm{G}_{\mathrm{b}}=$ Specific gravity of the binder

$\mathrm{G}_{\mathrm{mb}}=$ Bulk specific gravity of compacted mixture.

$\mathrm{G}_{\mathrm{mm}}=$ Maximum theoretical specific gravity of mixture.

$\mathrm{G}_{\mathrm{sa}}=$ Apparent specific gravity of the aggregate

$\mathrm{G}_{\mathrm{sb}}=$ Bulk specific gravity of the aggregate

$\mathrm{G}_{\mathrm{se}}=$ Effective specific gravity of the aggregate

$\mathrm{G}_{\mathrm{se}}=$ Effective specific gravity of the aggregate.

$\eta=$ Viscosity of air, $\mu \mathrm{Pa}^{*} \mathrm{sec}$, temperature of the test.

$\eta_{\mathrm{s}}=$ Viscosity of air, $\mu \mathrm{Pa}{ }^{*} \mathrm{sec}$, temperature of the calibration run.

$\mathrm{M}=$ Mass of sample used $(\mathrm{gm})$

$\mathrm{M}_{\mathrm{s}}=$ Mass of aggregate $(\mathrm{kg})$

$P_{200}=$ Percentage of aggregate passing the \#200 (0.075 mm) sieve.

$\mathrm{P}_{\mathrm{a}}=$ Percent air, assumed $4 \%$

$\mathrm{P}_{\mathrm{b}}=$ percent binder

$\mathrm{P}_{\mathrm{ba}}=$ Percent binder absorbed .

$P_{b e}=$ effective percent binder need equation

$P_{\text {be }}=$ Percent effective binder

$P_{i}=$ Percent passing sieve $\mathrm{i}$, in decimal form.

$\mathrm{P}_{\mathrm{s}}=$ Percent aggregate of stone.

$\rho=$ Density of the material $\left(\mathrm{gm} / \mathrm{cm}^{3}\right)$

$\rho_{\mathrm{s}}=$ Density of the standard sample.

$\rho_{\mathrm{w}} \quad=$ Density of water

$S=$ Specific surface Area $\left(\mathrm{m}^{2} / \mathrm{kg}\right)$

$\mathrm{SA}=$ Surface area $\mathrm{ft}^{2} / \mathrm{lb}$ or $\mathrm{m}^{2} / \mathrm{kg}$

$S F_{i}=$ Surface factor for sieve $\mathrm{i}$ 
$\mathrm{S}_{\mathrm{s}}=$ Specific surface of the standard sample, $\mathrm{m}^{2} / \mathrm{kg}$

$\mathrm{T}=$ Measured time interval, $\mathrm{s}$, for test sample.

$\mathrm{T}_{\mathrm{b}}=$ Average thickness of binder $(\mathrm{m})$

$\mathrm{T}_{\mathrm{F}} \quad=$ Average Film Thickness, microns;

$\mathrm{T}_{\mathrm{s}}=$ Measured time interval, $\mathrm{s}$, for calibration sample.

$\mathrm{V}=$ Bulk volume of the calibration sample $\mathrm{cm}^{3}$

$\mathrm{V}=$ Bulk volume of the test sample $\left(\mathrm{cm}^{3}\right)$, calculated using Equation 2.25.

$\mathrm{V}=$ Volume of material $\left(\mathrm{cm}^{3}\right)$

$\mathrm{V}_{\mathrm{be}}=$ Volume of binder $\left(\mathrm{m}^{3}\right)$

$V_{\text {be }}=$ Effective volume of asphalt cement (liters)

VFA $=$ Voids fill with asphalt (\%).

$V_{m}=$ Mix volume $\left(\mathrm{m}^{3}\right)$

VMA $=$ Voids in mineral aggregate $(\%)$.

$\mathrm{V}_{\mathrm{sb}}=$ Bulk volume of the aggregate $\left(\mathrm{m}^{3}\right)$

VTM $=$ Voids in total mix (\%).

$V_{v}=$ Volume of air voids

$\mathrm{W}=$ Weight of sample required (grams)

$W_{A}=$ Weight of mercury used to fill the cell with no sample (gm).

$W_{B}=$ Weight of mercury used to fill the cell with the sample (gm).

$\mathrm{W}_{\mathrm{be}}=$ Weight of effective binder per unit weight of aggregate ( $\mathrm{kg}$ binder/ $\mathrm{kg}$ aggregate)

$\mathrm{W}_{\mathrm{s}}=$ Mass of the stone, assumed $1 \mathrm{~kg}$

$\rho_{\mathrm{w}} \quad=$ Density of water $\left(\mathrm{grams} / \mathrm{cm}^{3}\right)$ 


\section{CHAPTER 1 INTRODUCTION}

\section{INTRODUCTION}

Over 90 percent of paved highways is the United States have a surface where an asphalt cement is used as the binder agent. The preponderance of these pavements are constructed with hot-mix asphalt concrete, HMAC. Asphalt concrete is a mixture of the binder, aggregates and air. Based on empirical evidence, the volume of air used in the mix design process is four percent. Under the performance grade specifications, the base grade of binder is selected based on the range of pavement temperatures expected for pavement's service conditions. The upper pavement temperature may be modified to account for traffic loads and traffic speeds. Aggregates used in asphalt concrete may be either natural sand, or crushed products, such as gravel and sand, or crushed products. Aggregates are further categorized as coarse of fine depending on whether the material is retained on or passes the $0.474 \mathrm{~mm}$ sieve. The component of the aggregate material which passes the $0.075 \mathrm{~mm}$ sieve is generally referred to as mineral filler or pan material.

The performance of asphalt surface roads is directly affected by the quality of the asphalt concrete. Several methods have been developed for determining the quantities of aggregate and asphalt cement used in the asphalt concrete. From the 1940's to the present time, the Marshall method was widely used in the United States. The Hveem method was in favor in some western states. In the 1990's, the SuperPave method was developed during the Strategic Highway Research Program. With the support of the Federal Highway Administration, FHWA, the SuperPave method is becoming widely implemented (Roberts, et al, 1996). The common thread between the Marshall, Hveem and SuperPave methods is the use of volumetric analysis to determine the percentage of asphalt binder needed in an asphalt concrete mixture. 
Volumetric analysis uses data on the specific gravity of the aggregate and the asphalt cement to determine volumetric parameters of the mix. The parameters used in the mix design are:

- Voids in Total Mix, VTM.

- Voids in the Mineral Aggregate, VMA.

- Voids Filled with Asphalt, VFA.

McLeod originally established the criteria for these parameters in the 1950's (McLeod, 1956). The criteria were refined and implemented into Marshall method by the Asphalt Institute. The Marshall criteria were adopted into SuperPave mix design method (Roberts, et al, 1996).

Natural sands and gravel were used in the fundamental research, which established the volumetric criteria. McLeod's evaluation of asphalt concrete performance established that an effective asphalt content of 10 percent by volume provided an optimum binder content. This analysis was based on computing asphalt film thickness based on the specific surface area of the aggregate. Specific surface area is the surface area per unit mass of the aggregate. McLeod (1956) used specific surface area factors computed from the specific gravity of the aggregate and the assumption that the aggregate are spherical. It was also assumed that the aggregate's diameter was equal to the size of the sieve the aggregate passes through.

Researchers at the National Center for Asphalt Technology, NCAT, evaluated McLeod's work (Kandhal, et al, 1998). This research challenged the methodology and criteria used in volumetric analysis. However, the NCAT research used the same surface area factors as McLeod.

This research consists of the evaluation aggregates used in the state of West Virginia. The specific surface area of the fine material was measured. This factor is important because the amount of asphalt needed to coat the aggregate depends on the specific surface area of the aggregate blend. The specific surface area of the blend is usually calculated based on the aggregate gradation and surface area factors. This involves multiplying the percentage aggregate passing each sieve by the surface area factor for each sieve. These area factors 
are obtained by assuming an aggregate specific gravity and that all the particles are spheres or cube shaped. Using the length of the side of the opening for each sieve, the surface area factors are determined using a simple equation. The assumption of a spherical aggregate shape was developed when gravels and natural sand were the predominant fine aggregate type used in asphalt concrete. They have not been validated for crushed aggregates which are currently used in asphalt concrete mixes.

\section{PROBLEM STATEMENT}

Asphalt concrete mix design requires the designer to select a combination of aggregates, asphalt binder and air to produce a mix that meets criteria established by the controlling agency. In West Virginia highway pavements are constructed under the specifications developed by the Division of Highways, $\mathrm{WVDOH}$. These specifications were derived from national organizations concerned with asphalt pavement construction. The WVDOH Marshall specifications were adopted from the Asphalt Institute publication MS-2 (Asphalt Institute, 1993). The WVDOH SuperPave specifications were adopted from AASHTO specifications MP 2-99 (1999) for SuperPave volumetric design.

While many criteria must be satisfied under both the Marshall and SuperPave mix design methods, one of the most challenging is the voids in the mineral aggregate, VMA. This parameter represents the space between the aggregate in the asphalt concrete. It is filled with the effective asphalt content and air voids, or the voids in the total mix, VTM. Historically, it has been found that a VTM in the range of three to five percent is required for durable concrete mixes. For mix design, a VTM of four percent is required for SuperPave mixes (WVDOH, 2000). Since the VTM is a constant, the VMA is then a measure of the volume of effective binder in the mix. The binder film thickness is a function of the volume of asphalt in the mix and the surface area of the aggregates. Since the purpose of the binder is to coat and bind the aggregates together, the binder film thickness is a key factor in asphalt concrete mix design. 
The origin of the VMA criteria used in both the Marshall and SuperPave mix design methods can be traced back to research performed by Norman McLeod in 1956 (McLeod, 1956). McLeod researched the behavior and performance of mixes with natural sand as the fine aggregate. Currently, West Virginia, as well as many other states, use crushed limestone fine aggregates for many of their mixes. Depending on haul distance, crushed limestone fine aggregate may be more economical than natural sand. Furthermore, use of natural sand is effectively limited under the SuperPave consensus aggregate criteria for fine aggregate angularity. The differences in the shape and texture of natural sand versus crushed limestone fine aggregate, leads to the question of whether or not the volumetric criteria developed for natural sands is appropriate for crushed limestone fine aggregate.

\section{OBJECTIVE}

The objective of this research is to evaluate the effect of aggregate surface area on the selection of the optimum asphalt content. Aggregate specific surface area is not currently an explicit design criterion in either the SuperPave or Marshall mix design methods. However, specific surface area is the controlling factor in determining asphalt film thickness. The VMA criterion effectively controls the minimum asphalt film thickness. Since the VMA criteria were developed for natural sand mixes, evaluation of the criteria for the crushed limestone sand mixes were evaluated.

Existing models of specific surface area assume the aggregate particles are spherical and the effect texture is not considered. To support the main objective of the research, a direct measure of the specific surface area was sought. Due to the sensitivity of specific surface area on fine materials, the specific surface area of the aggregate passing the $0.15 \mathrm{~mm}$ sieve were measured in the laboratory. These evaluations were performed for a range of aggregates used in West Virginia. 


\section{SCOPE AND LIMITATIONS}

The research reported herein focuses on aggregate materials and procedures that are used for the design of mixes for the West Virginia Division of Highways. The materials selected for the study were samples from stockpiles across the state of West Virginia. Six samples of crushed limestone fine aggregate and one sample of natural sand were used in the study. In addition, nine samples of baghouse fines were collected and evaluated. Baghouse fines is the fine material that is separated from the aggregate when the aggregates are dried for the production of asphalt concrete.

The results produced in this research were based on the volumetric analysis for hot-mix asphalt concrete. These results are theoretical. These results were not verified with experimentation.

The specific surface area, surface area per unit mass, of materials is a function of the particle size. Small particles have a greater specific surface area than large particles. This research focused on measuring the surface area of particles that pass the $0.15 \mathrm{~mm}$ sieve. The specific surface area of the material finer than the $0.15 \mathrm{~mm}$ sieve is much greater than the specific surface area of larger size aggregates. Hence, the research focused on measurements of these surface areas.

Equipment for measuring the surface area of larger aggregates was not available for the research. Surface area of the aggregates were estimated using the traditional method. Any error resulting from this approach is mitigated by the fact that the larger aggregates contribute little to the total surface area of the aggregates in the mix.

\section{THESIS OVERVIEW}

This thesis is organized into five chapters and five appendixes. Following this introductory chapter, a review of the literature is presented in Chapter 2. The research approach is described in Chapter 3. The data collected during the research and the subsequent analysis are presented in Chapter 4. Conclusions and recommendation are presented in Chapter 5 


\section{CHAPTER 2 LITERATURE REVIEW}

\section{INTRODUCTION}

The research presented herein builds on volumetric concepts, which are well established in the literature. The volumetric criteria used by the West Virginia Department of Transportation, WVDOT, are presented since they control mix designs in the region of interest. However, the WVDOT criteria are based on the recommendations of the Asphalt Institute and the America Association of State Highways and Transportation Officials, AASHTO, for the Marshall and SuperPave methods, respectively. Hence, the scope of the research has nation wide applications.

The volumetric criteria are followed by a presentation of the equation used for volumetric analysis. These relationships can be derived from the definitions of the volumetric terms. However, the relationships are well documented in the literature. Hence they are presented rather than derived herein.

The volumetric parameter, which controls the minimum asphalt content, is the voids in the mineral aggregate, VMA. The literature for establishing the VMA criteria is documented due to the importance of this parameter on mix designs. In a NCAT study, the relationships between volumetric parameters and the asphalt film thickness were derived. These equations are presented since they are fundamental to the research presented herein.

Volumetric analysis is dependent on the determination of specific gravity of the materials. The procedures for measuring the specific gravity of the fine aggregates and mineral fillers and baghouse fines are presented to document the test methods used during the research.

The ASTM method for measuring the specific gravity of portland cement was used to measure the specific gravity of the mineral fillers and the baghouse fines. This was necessary since there is not a specific test method for measuring the specific gravity of these materials. 
As documented in this chapter, the volume of effective binder in asphalt concrete can be computed from film thickness criteria, gradation, and the specific surface area factors. However, estimating total asphalt content requires an estimate of the amount of absorbed asphalt. This is normally evaluated after mixing the asphalt concrete. The FHWA has presented an equation for estimating the effective specific gravity of the aggregates as a function of the bulk and the apparent specific gravity. The percent absorbed binder can then be computed from the effective and the bulk specific gravity of the aggregate and the specific gravity of the binder content.

Evaluation of the aggregate specific surface area is necessary for evaluating asphalt film thickness. Several authors have addressed this topic, starting with Hveem in 1942 (Campen, et al, 1959). Historically, specific surface area was computed based on an assumed aggregate shape. The work of asphalt technologists using this approach is documented. However, the specific surface area of the fine materials can be measured using techniques developed in the portland cement industry. The Blaine finesse meter is one such device and it was used to measure the specific surface area of the aggregate materials finer than $0.15 \mathrm{~mm}$. The test method for using the Blaine fineness meter is documented.

The final section of the literature review documents the equations developed by Kandhal et al (1998-1) for estimating film thickness from the volume of effective binder, specific surface area and the mass of the aggregate in a mix.

\section{VOLUMETRIC CRITERIA}

Volumetric analysis is used to determine the volume of asphalt and aggregates needed to make an asphalt mix with the desired properties. However, it is impractical to measure aggregate volumes in a production environment. Therefore, the mass and density of the materials are used to compute volumetric properties. The volumetric parameters controlled in both the Marshall and SuperPave mix design methods are the voids in total mix (VTM), 
voids in the mineral aggregate (VMA), voids filled with asphalt (VFA) and the dust to asphalt ratio. The WVDOH volumetric mix design requirements are given in Tables 2.1 and 2.2 for the Marshall (WVDOT MP 402.02.22.2000) and SuperPave (WVDOT MP 402.02.28.2000) mix design methods respectively.

TABLE 2.1 MARSHALL MIX CRITERIA

\begin{tabular}{|c|c|c|c|}
\hline Design Criteria (1) & $\begin{array}{c}\text { Wearing I } \\
\text { Medium } \\
\text { Traffic Design }\end{array}$ & $\begin{array}{c}\text { Base II } \\
\text { Heavy } \\
\text { Traffic } \\
\text { Design }\end{array}$ & $\begin{array}{c}\text { Base I } \\
\text { Heavy } \\
\text { Traffic } \\
\text { Design }\end{array}$ \\
\hline $\begin{array}{c}\text { Compaction, number } \\
\text { of blows, Each end of } \\
\text { specimen }\end{array}$ & 50 & 75 & 112 \\
\hline $\begin{array}{c}\text { Stability, (Newtons) } \\
\text { Minimum }\end{array}$ & 5,300 & 8,000 & 13,300 \\
\hline Flow, (0.25 mm) & $8-16$ & $8-14$ & $12-21$ \\
\hline $\begin{array}{c}\text { Air Voids (\%) Design } \\
\text { based on a midpoint } \\
\text { of a range }\end{array}$ & $3-5$ & $3-5$ & $3-6$ \\
\hline $\begin{array}{c}\text { Voids Filled with } \\
\text { Asphalt (\%) }\end{array}$ & $65-78$ & $65-75$ & $63-75$ \\
\hline VMA (\%) & 15 & 13 & 11 \\
\hline
\end{tabular}

Notes

1. The fines-to-asphalt ratio shall be within the range of 0.6 to 1.2 based on the asphalt content of the mix. 
TABLE 2.2 SUPERPAVE MIX DESIGN CRITERIA

\begin{tabular}{|c|c|c|c|c|c|}
\hline \multicolumn{5}{|l|}{ Design Air Voids } & $4 \%$ \\
\hline \multicolumn{5}{|c|}{ Fines to Effective Asphalt ${ }^{1}$} & $0.6-1.2$ \\
\hline \multicolumn{5}{|c|}{ Tensile strength ratio $^{2}$} & $80 \% \min$ \\
\hline \multirow{3}{*}{$\begin{array}{l}\text { Minimum Voids } \\
\text { in the Mineral } \\
\text { Aggregate }\end{array}$} & \multicolumn{5}{|c|}{ Nominal Maximum Size } \\
\hline & $37.5 \mathrm{~mm}$ & $25 \mathrm{~mm}$ & $19 \mathrm{~mm}$ & $12.5 \mathrm{~mm}$ & $9.5 \mathrm{~mm}$ \\
\hline & 11 & 12 & 13 & 14 & 15 \\
\hline \multirow{2}{*}{$\begin{array}{l}\text { Design EASL } \\
\text { millions }\end{array}$} & \multicolumn{3}{|c|}{$\begin{array}{c}\text { Percent Maximum } \\
\text { Theoretical Specific } \\
\text { Gravity }\end{array}$} & \multirow{2}{*}{\multicolumn{2}{|c|}{$\begin{array}{l}\text { Voids Filled with } \\
\text { Asphalt }^{3,4,5}\end{array}$}} \\
\hline & Ninitial & $\begin{array}{c}\text { Ndesig } \\
\mathrm{n}\end{array}$ & Nmax & & \\
\hline$<0.3$ & $\leq 91.5$ & 96 & $\leq 98.0$ & & $\frac{-80}{-80}$ \\
\hline $0.3-3$ & $\leq 90.5$ & 96 & $\leq 98.0$ & & $5-78$ \\
\hline $3-10$ & $\leq 89.0$ & 96 & $\leq 98.0$ & & $5-75$ \\
\hline $10-30$ & $\leq 89.0$ & 96 & $\leq 98.0$ & & $5-75$ \\
\hline$\geq 30$ & $\leq 89.0$ & 96 & $\leq 98.0$ & & $5-75$ \\
\hline
\end{tabular}

Notes

2. Dust to binder range 0.8 to 1.6 for coarse aggregate blends.

3. If mix fails, use an approved antistrip and redesign with antistrip in the mix. All design tests must be with the antistrip in the mix.

4. For 9.5 nominal maximum aggregate size mixes and design ESAL $\geq 3$ million, VFA range is 73 to 76 percent.

5. For $25 \mathrm{~mm}$ nominal maximum aggregate size mixes, the lower limit of the VFA range shall be $64 \%$ for design traffic levels < 3 million ESALs.

6. For $37.5 \mathrm{~mm}$ nominal maximum aggregate size mixes, the lower limit of the VFA range shall be $64 \%$ for all design traffic levels. 


\section{VOLUMETRIC ANALYSIS}

The volumetric analysis consists of computing volumetric parameters from laboratory tests. Aggregate bulk and apparent specific gravity are measured using AASHTO T84-94 and T85-91 methods for fine and course aggregates, respectively. The specific gravity of the asphalt cement is measured using AASHTO 228-94 method. The bulk and maximum theoretical specific gravity of the asphalt concrete are measured using AASHTO T166-06 and T209-99, respectively. Once these parameters are measured, the volumetric analysis is performed using the equations (Roberts, et al, 1996):

$$
\begin{aligned}
& V T M=100\left(1-\frac{G_{m b}}{G_{m m}}\right) \\
& V M A=\left(100-\frac{G_{m b}\left(1-P_{b}\right)}{G_{s b}} \times 100\right) \\
& V F A=100\left(\frac{V M A-V M T}{V M A}\right) \\
& \mathrm{F} / \mathrm{A}=\frac{\mathrm{P}_{200}}{P_{b}} \\
& \mathrm{~F} / \mathrm{A}=\frac{\mathrm{P}_{200}}{P_{b e}}
\end{aligned}
$$

The percent effective binder $P_{b e}$, is computed as:

$$
\begin{aligned}
& P_{b e}=P_{b}-\frac{P_{b a}}{100} \times P_{s} \\
& P_{s}=100-P_{b} \\
& P_{b a}=100\left(\frac{G_{s e}-G_{s b}}{G_{s e} \times G_{s b}}\right) \times G_{b}
\end{aligned}
$$




$$
G_{s e}=\frac{100-P_{b}}{\frac{100}{G_{m m}}-\frac{P_{b}}{G_{b}}}
$$

Where:

VTM $=$ Voids in total mix (\%).

VMA $=$ Voids in mineral aggregate $(\%)$.

VFA $=$ Voids fill with asphalt $(\%)$.

$\mathrm{G}_{\mathrm{sb}}=$ Bulk specific gravity of aggregate.

$\mathrm{G}_{\mathrm{mb}}=$ Bulk specific gravity of compacted mixture .

$\mathrm{G}_{\mathrm{mm}}=$ Maximum theoretical specific gravity of mixture.

$\mathrm{F} / \mathrm{A}=$ Fines to asphalt ratio

$P_{200}=$ Percentage of aggregate passing the $\# 200(0.075 \mathrm{~mm})$ sieve.

$\mathrm{P}_{\mathrm{b}}=$ Percent binder

$P_{b e}=$ Effective percent binder need equation

$\mathrm{P}_{\mathrm{ba}}=$ Percent binder absorbed.

$\mathrm{P}_{\mathrm{s}}=$ Percent aggregate of stone.

$\mathrm{G}_{\mathrm{se}}=$ Effective specific gravity of the aggregate.

Equation 2.4 is used for the Marshall method and Equation 2.5 is used for the SuperPave method.

\section{VOIDS IN THE MINERAL AGGREGATE}

The design and study of asphalt-paving mixtures was based on the volumetric considerations since the topic was introduced N. W. McLeod in 1956 (McLeod, 1956). McLeod's analysis was based on a relation between the volumes of the total aggregate, the asphalt binder and the air voids in the mixture. The specific gravity of the asphalt cement and aggregates were 1.01 and 2.65, respectively. McLeod (1956), working with aggregates with 100 percent passing the 3/4" sieve, 5 percent air voids and a minimum of 10 percent binder by volume. This resulted in the recommendation for a minimum of 15 percent voids in the mineral aggregate. 
Later, the VMA analysis was adjusted to account for the absorption of the binder into the aggregates (McLeod, 1959). VMA is currently defined as "the volume of intergranular void space between the aggregate particles of a compacted paving mixture that includes the air voids and the volume of the asphalt not absorbed into the aggregate". McLeod's recommendations were incorporated into the Asphalt Institute's Marshall mix design procedure in 1964. The Asphalt Institute's recommendations for the Marshall procedure were directly implemented into the SuperPave design method.

Kandhal et al (1998-1). presented equations for estimating volumetric properties based on asphalt film thickness, surface area of the aggregates and the specific gravity of the materials. There equations were presented in numerical example format. They have been converted to a variable definition format for this review.

$$
\begin{aligned}
& W_{b e}=S A \times G_{b} \times T_{b} \times \rho_{w} \\
& P_{b e}=\frac{W_{b e}}{1+W_{b e}} \times 100 \\
& V_{s b}=\frac{W_{s}}{G_{s b} \times \rho_{w}} \\
& V_{m}=\frac{V_{b e}+V_{s b}}{\left(100-P_{a}\right)} \times 100 \\
& V_{v}=V_{m}-V_{b e}-V_{s b} \\
& V M A=\frac{V_{v}+V_{b e}}{V_{m}} \times 100
\end{aligned}
$$

Where:

$W_{\text {be }}=$ Weight of effective binder per unit weight of aggregate $(\mathrm{kg}$ binder/ $\mathrm{kg}$ aggregate)

$\mathrm{SA}=$ Surface area of aggregate per unit weight of aggregate $\left(\mathrm{m}^{2} / \mathrm{kg}\right.$ aggregate)

$\mathrm{G}_{\mathrm{b}}=$ Specific gravity of binder 


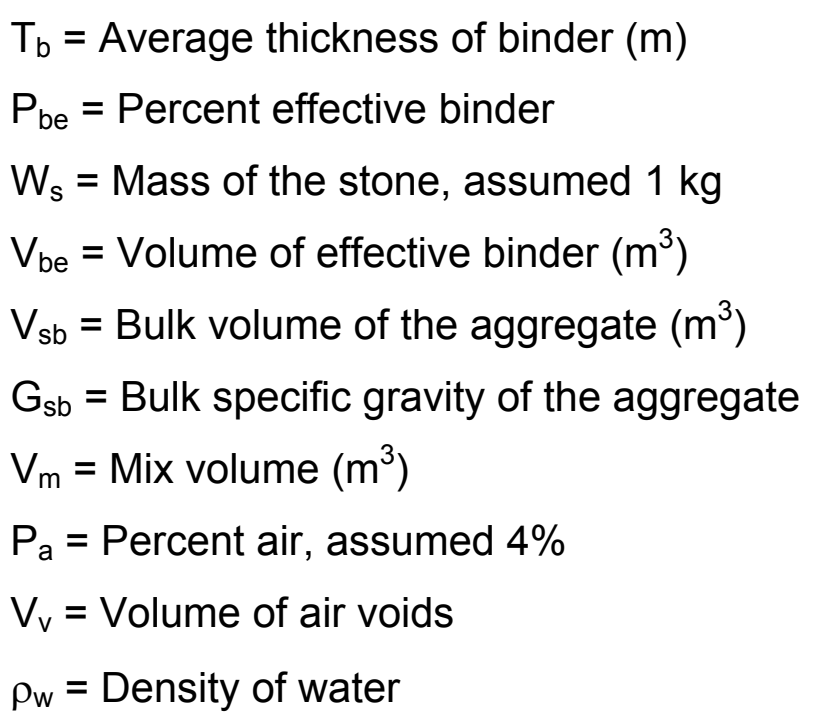

It should be noted that Equation 2.11 is based on effective binder content. Traditionally, $P_{b e}$ is based on total asphalt content i.e. the denominator of equation 2.11 is traditionally $\left(W_{s}+W_{b e}+W_{b a}\right.$. These equations assume the density of water is $1 \mathrm{gm} / \mathrm{cc}$ so the differences between specific gravity and density can be numerically ignored.

\section{SPECIFIC GRAVITY OF AGGREGATES}

Due to the surface voids of aggregates, several definitions of specific gravity have been developed to account for the treatment of the volume of the voids at the aggregate surface. The apparent specific gravity, $\mathrm{G}_{\mathrm{sa}}$, is the mass of the material divided by the volume of the aggregate, including internal impervious voids. However, the surface voids of aggregates are too small to impact the packing of aggregates in an asphalt concrete mix. Therefore, the bulk specific gravity, $\mathrm{G}_{\mathrm{sb}}$, is defined as the mass of the material divided by the volume of the material plus the volume of the surface voids. Finally, since asphalt cement cannot fill the surface voids as effectively as water, the effective specific gravity, $\mathrm{G}_{\mathrm{se}}$, is defined as the mass of the material divided by the volume of the material, plus the volume of the surface voids, minus the volume of the voids filled with asphalt.

Due to the range of aggregate sizes, different test methods are required for determining specific gravity. Coarse aggregates were not considered in this 
research so the test method is not presented. The specific gravity of fine aggregates is determined with ASTM C 128-01. This method is applied to the fine materials with the mineral fillers present. However, due to the significance of the specific gravity of mineral filler and baghouse fines in this research, a test method for measuring their specific gravity directly was sought. ASTM C 188-95 covers measuring the density of hydraulic cements. Since the particle size of the mineral fillers and hydraulic cement is similar, this method was used to check the specific gravity of the mineral fillers.

\section{SPECIFC GRAVITY FOR FINE AGGREGATE}

ASTM C 128-01 requires drying of the aggregate, then immersion in water for 15 to 19 hours, drying the sample to the Saturated Surface Dry, SSD, condition. The mass of the sample is measured in the SSD condition, submerged in water and after drying to a constant weight. The SSD condition is determined using a specified conical mold and a tamper. The material is placed in the cone, tamped twenty five times and the cone is removed. If the material slumps, the SSD condition is reached, but if it does not slump it is necessary to dry the sample further.

After reaching the SSD condition, $500 \pm 1$ grams of the sample are placed in a pycnometer (Figure 2.4) charged with water. All air voids are removed and the pycnometer is filled with water to the calibration line. The mass is recorded. The material is taken out and placed in the oven at a temperature of $110{ }^{\circ} \mathrm{C}$ for drying. The mass of the dry material is determined.

The following formulas are used compute specific gravity and absorption: Bulk Specific Gravity (Oven Dry basis)

$$
G_{s b}=\frac{A}{B+D-C}
$$

Bulk Specific Gravity (SSD Basis)

$$
G_{s b_{S D}}=\frac{D}{B+D-C}
$$




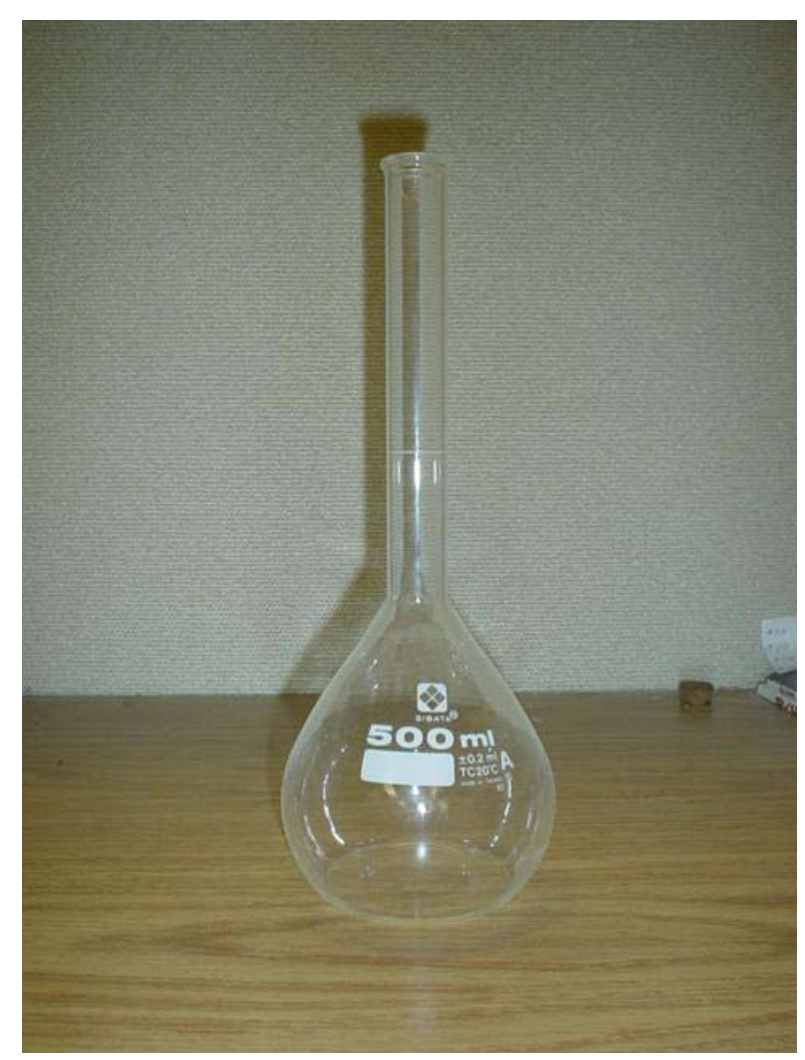

FIGURE 2.1 PHOTO OF PYCNOMETER FLASK.

Apparent Specific Gravity

$G_{s a}=\frac{A}{B+A-C}$

Absorption $=\frac{D-A}{A} \times 100$

Where:

$A=$ Mass of oven-dry sample in air, grams

$B=$ Mass of pycnometer filled to calibration mark, grams.

$\mathrm{C}=$ Mass of pycnometer, sample, and water to calibration mark, grams.

$D=$ Mass of saturated-surface-dry sample in air, grams . 


\section{SPECIFIC GRAVITY FOR MINERAL FILLER AND BAGHOUSE FINES}

There is not a specific test method for determining the specific gravity of mineral fillers and baghouse fines. ASTM C 188-95, Standard Test Method for Density of the Hydraulic Cement, was used to measure the density of the baghouse fines due to the fineness of the material. This method was also used to determine the specific gravity of the mineral filler of some samples.

ASTM C 188-95 uses a LeChatelier flask (shown in Figure 2.2) to directly measure the volume of a sample of material. The flask is filled with kerosene between the 0 and $1 \mathrm{ml}$ marks. It is then placed in a water bath at a temperature of $23 \pm 2^{\circ} \mathrm{C}$. Then about 60 grams of the material is introduced in the flask. While adding the material, it is necessary to check that no material adheres to the walls of the flask. After the material is added, the flask is placed in an inclined position and rotated to evacuate all air. Finally, the flask is placed back in the water bath and the temperature is equilibrated to be with in $\pm 0.2^{\circ} \mathrm{C}$ of the temperature during the initial volume measurement. The second volume measurement is recorded.

The density is calculated as:

$$
\rho=\frac{M}{V}
$$

Where:

$\rho=$ Density of the material $\left(\mathrm{gm} / \mathrm{cm}^{3}\right)$

$\mathrm{M}=$ Mass of sample used (gm)

$V=$ Volume of material $\left(\mathrm{cm}^{3}\right)$ 


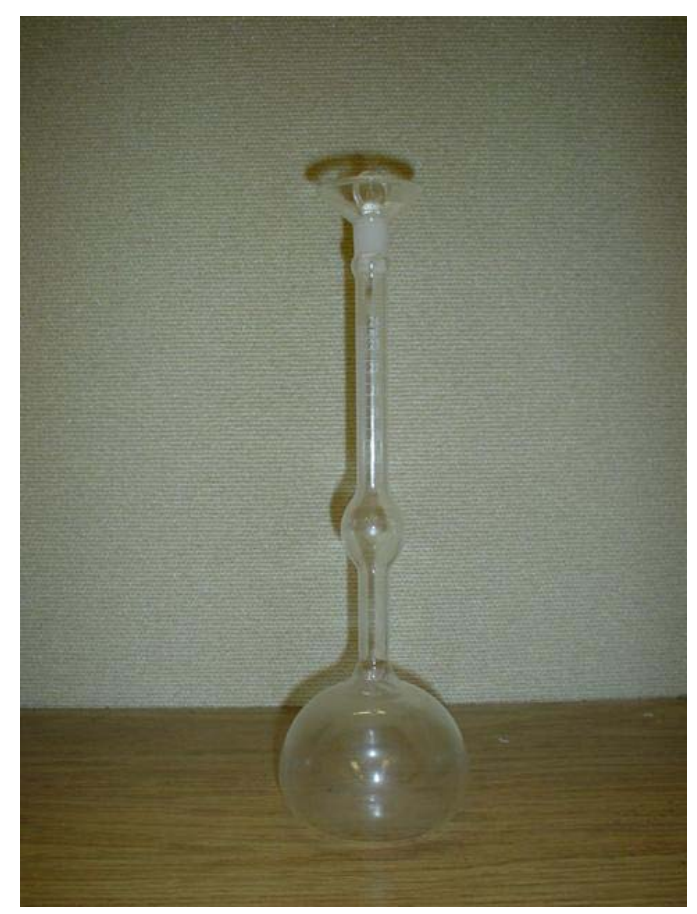

FIGURE 2.2 PHOTO OF LE CHATELIER FLASK

\section{ESTIMATE AGGREGATE EFFECTIVE SPECIFIC GRAVITY}

The effective specific gravity of an aggregate must be known in order to determine the absorbed asphalt content. This can be computed if the percent binder, specific gravity of the binder and the maximum theoretical specific gravity of the mix is known, as shown in Equation 2.9. However, the U.S. Department of Transportation (Harman et al, 1999) presents a equation where an estimate of the effective specific gravity, $G_{s e}$, is obtained from the bulk specific gravity, $G_{s b}$, and the apparent specific gravity, $\mathrm{G}_{\mathrm{sa}}$, of an aggregate.

$$
G_{s e}=G_{s b}+F\left(G_{s a}-G_{s b}\right)
$$

Where:

$\mathrm{G}_{\mathrm{se}}=$ Effective specific gravity of the aggregate

$\mathrm{G}_{\mathrm{sb}}=$ Bulk specific gravity

$\mathrm{G}_{\mathrm{sa}}=$ Apparent specific gravity of the aggregate 
$\mathrm{F}=$ Factor 0.8

The factor of 0.8 is to compensate the difference between the absorption of water in relation to the absorption of the asphalt binder.

\section{AGGREGATE SURFACE AREA}

\section{METHODS FOR ESTIMATING SURFACE AREA}

Hveem developed a method for estimating the surface area of aggregates based on gradation using surface areas factors proposed by L. N. Edwards (Roberts, et al, 1996). These factors are based on the diameter of the aggregate that is equivalent to the size or the opening of the sieve. Edwards reportedly represented the aggregates as spheres. Edwards surface area factors are presented in Table 2.3.

The surface area per unit mass for an aggregate blend is determined by summing the product of the surface area factor times the percent material passing each sieve size (Roberts, et. al, 1996), expressed mathematically as:

$$
S A=\sum S F_{i} \times P_{i}
$$

Where

$$
\begin{aligned}
& S A=\text { Surface area } \mathrm{ft}^{2} / \mathrm{lb} \text { or } \mathrm{m}^{2} / \mathrm{kg} \\
& \mathrm{SF}_{\mathrm{i}}=\text { Surface factor for sieve } \mathrm{i} \\
& \mathrm{P}_{\mathrm{i}}=\text { Percent passing sieve } \mathrm{i}, \text { in decimal form. }
\end{aligned}
$$

The surface area factor for all sieves greater than $4.75 \mathrm{~mm}$ is applied to the sieve corresponding to the maximum aggregate size and therefore $P_{1}$ is always 1.00 .

An inherent assumption of Hveem's method for computing surface area is that the particles are spheres with smooth sides. Craus and Ishai (1977) performed a literature review on the effects of this assumption and concluded that Hveem's method provided reasonable approximations of surface area. 
TABLE 2.3 SURFACE AREA FACTORS USED BY HVEEM, PROPOSED BY EDWARDS

\begin{tabular}{|c|c|c|c|c|c|c|c|c|}
\hline Sieve Size \# & $>\# 4$ & $\# 4$ & $\# 8$ & $\# 16$ & $\# 30$ & $\# 50$ & $\# 100$ & $\# 200$ \\
\hline Diameter $(\mathrm{mm})$ & & 4.75 & 2.36 & 1.18 & 0.60 & 0.30 & 0.15 & 0.075 \\
\hline $\begin{array}{c}\text { Surface Area } \\
\left(\mathrm{m}^{2} / \mathrm{kg}\right)\end{array}$ & 0.41 & 0.41 & 0.82 & 1.64 & 2.87 & 6.14 & 12.29 & 32.77 \\
\hline Surface Area $\left(\mathrm{ft}^{2} / \mathrm{lb}\right)$ & 2 & 2 & 4 & 8 & 14 & 30 & 60 & 160 \\
\hline
\end{tabular}

Craus and Ishai (1977) assumed that all particles have a sphere or a cube form with $D$ being the diameter or length of the edge and $\rho$ the density of the aggregate in $\mathrm{kg} / \mathrm{m}^{3}$ to calculate the surface area (S) in $\mathrm{m}^{2} / \mathrm{kg}$ as:

$$
S=\frac{6}{\rho \cdot D}
$$

Table 2.4 presents the surface area factors for a specific gravity of 2.65 . These values are somewhat different than the surface area factors presented by Hveem. The reasons for this discrepancy are not described in the literature.

TABLE 2.4 CRAUS AND ISHAI SURFACE AREA FACTORS

\begin{tabular}{|c|c|c|c|c|c|c|c|}
\hline Sieve \# & $\# 4$ & $\# 8$ & $\# 16$ & $\# 30$ & $\# 50$ & $\# 100$ & $\# 200$ \\
\hline $\mathrm{D}(\mathrm{mm})$ & 4.75 & 2.36 & 1.18 & 0.6 & 0.3 & 0.15 & 0.075 \\
\hline $\begin{array}{c}\text { Surface Area } \\
\left(\mathrm{m}^{2} / \mathrm{kg}\right)\end{array}$ & 0.48 & 0.96 & 1.90 & 3.77 & 7.55 & 15.10 & 30.20 \\
\hline $\begin{array}{c}\text { Surface Area } \\
\left(\mathrm{ft}^{2} / \mathrm{lb}\right)\end{array}$ & 2.33 & 4.68 & 9.37 & 18.42 & 36.85 & 73.70 & 147.40 \\
\hline
\end{tabular}

Duriez and Arrambide propose another method for the calculation of surface area (Duriez 1962). This method is being used in France and consists on applying the following formula: 
$S=135 \cdot A+12 \cdot B+2.3 \cdot C$

Where:

$\mathrm{S}=$ Specific surface area $\left(\mathrm{m}^{2} / \mathrm{kg}\right)$

$A=$ Percentage by weight of the fraction finer than $80 \mu \mathrm{m}$

$B=$ Percentage by weight in the range between $80 \mu \mathrm{m}-0.315 \mathrm{~mm}$

$C=$ Percentage by weight in the range between $0.315 \mathrm{~mm}-5.0 \mathrm{~mm}$

Equation 2.24 is similar to Equation 2.22 if only three sieve sizes are considered. The coefficient for the fine material, passing the $80 \mu \mathrm{m}$ sieve should be similar to the surface area factors for material passing the $75 \mu \mathrm{m}$. However, the Edwards-Hveem and Cruas-Ishai factors are approximately one quarter of the Duriez-Arrambide values.

Chapuis and Legare (1992) evaluated the Hveem-Edwards, DuriezArrambide and Craus-Ishai methods for a clean sand with 2 percent mineral filler. Based on this analysis, they recommended computing surface area based on the edge dimension of the retaining sieve and the percent retained on the sieve, i.e.:

$$
S=\frac{6}{\rho} \sum \frac{P_{N o D}-P_{N o d}}{d_{i}}
$$

Comparison of this method for computing surface area of sands to the other methods demonstrated that it produced similar estimates to the Craus-Ishai method but estimated a higher surface area than either the Hveem-Edwards or Duriez-Arrambide methods.

Chapuis and Legare (1992) used two methods for determining the surface area of mineral fillers. One method used sieving of the mineral fillers and Equation 2.25 to compute the specific surface area. The other method measured specific surface area of mineral fillers using the Blaine air permeability apparatus (ASTM C204). The resulting values for specific surface area of mineral fillers were: 


\begin{tabular}{lcc} 
Material & $\begin{array}{c}\text { Computed Surface } \\
\text { Area }\left(\mathrm{m}^{2} / \mathrm{kg}\right)\end{array}$ & $\begin{array}{c}\text { Measured Surface } \\
\text { Area }\left(\mathrm{m}^{2} / \mathrm{kg}\right)\end{array}$ \\
\hline Limestone & 325 & 263 \\
Dolomite & 206 & 202 \\
Basalt & 247 & 247
\end{tabular}

The measured and computed values are very close for the dolomite and basalt mineral fillers. The limestone values are different by 22.9 percent. In all cases, the surface areas are much greater than the Hveem-Edwards surface area factor of 32.77. The authors did not state if these materials were manufactured by crushing. However, based on the geological classification of the rocks it would be reasonable to assume the materials were produced by crushing.

\section{METHODS FOR MEASURING AGGREGATE SURFACE AREA}

There are several tests for the measurement of surface area of fine materials. The surface area for hydraulic cement is used as a quality control measure. The Blaine air permeability apparatus, shown in Figure 2.3, and the Wagner turbidimeter are commonly used ASTM procedures. The Blaine method was used in this research, so this procedure is explained. This is also the method used by Chapuis and Legare (1992).

The basic procedure for using the Blaine air permeability apparatus, ASTM C-204, consists of placing a bed of material, with a specific porosity, in the permeability cell. A vacuum is used to force air through the sample to a manometer which measures the vacuum. The time required to cause a change in the manometer reading from the initial point to a final point is related to the size of the particles, at a specific porosity.

For calibration, the bulk volume of the compacted bed is measured using a National Institute of Standards standard material No. 114. This is a portland cement material with independently determined specific surface area. The specific surface area of the calibration sample used was $396.6 \mathrm{~m}^{2} / \mathrm{kg}$. 


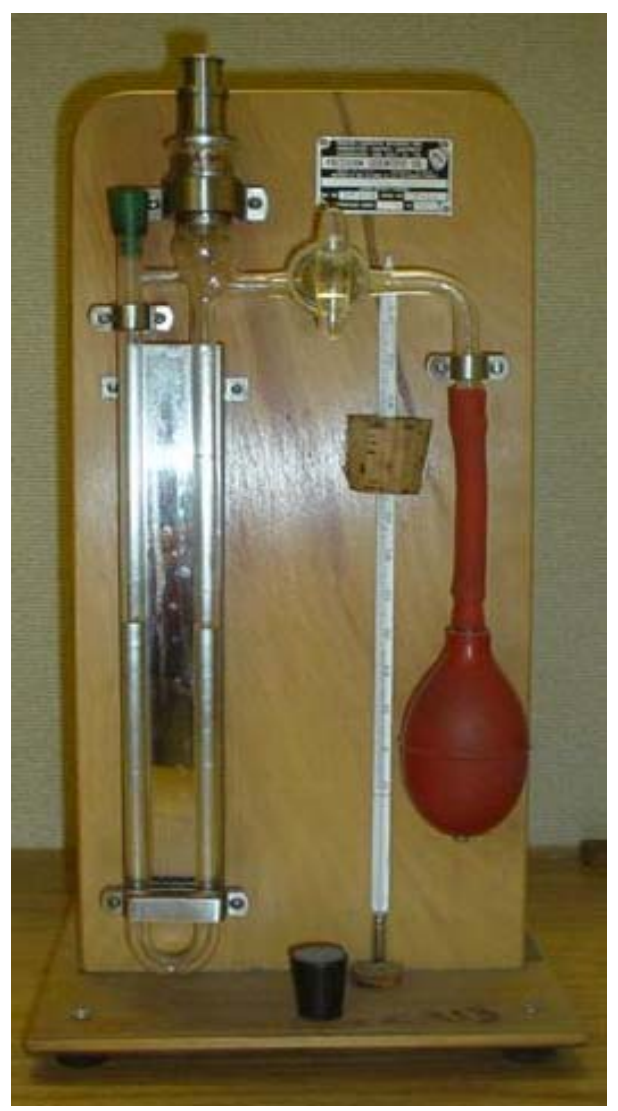

FIGURE 2.3 AIR PERMEABILITY APPARATUS (BLAINE)

The volume occupied by the calibration material is obtained by placing two filters completely over the perforated metal disk located at the bottom of the permeability cell. Then the permeability cell is filled with mercury, a plate of glass is used to level it, making sure there is no air voids between the mercury and the glass. The mercury is taken out of the cell and its weight is determined. The next step is to place a new filter in the cell and $2.8 \mathrm{gm}$ of the standard material is added to the cell and covered with a filter. The rest of the cell is filled with mercury and leveled as explained before. The new weight of the mercury is measured. The following formula is used to calculate the bulk volume of the calibration material:

$$
V=\left(W_{A}-W_{B}\right) / D
$$

Where: 
$\mathrm{V}=$ Bulk volume of the calibration sample $\mathrm{cm}^{3}$.

$\mathrm{W}_{\mathrm{A}}=$ Weight of mercury used to fill the cell with no sample (gm).

$W_{B}=$ Weight of mercury used to fill the cell with the sample $(\mathrm{gm})$.

$D=$ Density of the mercury at the test temperature $\mathrm{Mg} / \mathrm{m}^{3}$.

The procedure is repeated two times and the average of the volume is used for calculating the weight of the test samples.

The preparation of the test sample starts by enclosing it in a jar and shaking for two minutes. It is allowed to rest for another two minutes. This is done to break up the lumps and agglomerates. The required weight of the test sample is estimated as:

$W=\rho \cdot V \cdot(1-\varepsilon)$

Where:

$\mathrm{W}=$ Weight of sample required (grams)

$\rho=$ Density of the test sample $\left(\mathrm{grams} / \mathrm{cm}^{3}\right)$

$V=$ Bulk volume of the test sample $\left(\mathrm{cm}^{3}\right)$, calculated using Equation 2.26.

$\varepsilon=$ Porosity of the test sample.

Porosity is the ratio of the volume of voids in the sample divided by the bulk volume of the sample.

The bed of test sample is prepared by placing the perforated disk and a paper filter in the cell. The sample with a weight calculated with Equation 2.27 is placed in the cell. Another filter is added on the top and pressed down using the plunger until the collar of the plunger touches the top of the cell. The plunger is removed, rotated $90^{\circ}$ and pressed again.

The cell is to connected to the manometer. Air is evacuated from one arm of the tube, bringing the oil to the top mark. The vacuum is released and the time for the liquid to go from the second mark to the third mark is measured. The time and temperature are recorded.

For the each test sample, three measurements of time are made for four different levels of porosity. Using the recorded times and temperatures, and the 
data obtained during calibration the specific surface area is computed using Equation 2.28 or 2.29. Equation 2.28 is used when the temperature range is within $\pm 3^{\circ} \mathrm{C}$ of the calibration temperature and 2.29 otherwise.

$$
\begin{gathered}
S=\frac{S_{s} \rho_{s}\left(b_{s}-\varepsilon_{s}\right) \sqrt{\varepsilon^{3}} \sqrt{T}}{\rho(b-e) \sqrt{\varepsilon_{s}^{3}} \sqrt{T_{s}}} \\
S=\frac{S_{s} \rho_{s}\left(b_{s}-\varepsilon_{s}\right) \sqrt{\eta_{s}} \sqrt{\varepsilon^{3}} \sqrt{T}}{\rho(b-e) \sqrt{\varepsilon_{s}^{3}} \sqrt{T_{s}} \sqrt{\eta}}
\end{gathered}
$$

Where:

$\mathrm{S}=$ Specific surface of the test sample, $\mathrm{m}^{2} / \mathrm{kg}$.

$\mathrm{S}_{\mathrm{s}}=$ Specific surface of the standard sample, $\mathrm{m}^{2} / \mathrm{kg}$

$\mathrm{T}=$ Measured time interval, $\mathrm{s}$, for test sample.

$\mathrm{T}_{\mathrm{s}}=$ Measured time interval, $\mathrm{s}$, for calibration sample.

$\eta=$ Viscosity of air, $\mu \mathrm{Pa}^{*} \mathrm{sec}$, temperature of the test.

$\eta_{\mathrm{s}}=$ Viscosity of air, $\mu \mathrm{Pa}{ }^{*} \mathrm{sec}$, temperature of the calibration run.

$\varepsilon=$ Porosity of prepared bed of test sample.

$\varepsilon_{\mathrm{s}}=$ Porosity of prepared bed of the calibration sample.

$\rho=$ Density of the test sample.

$\rho_{\mathrm{s}}=$ Density of the standard sample.

$\mathrm{b}=$ Constant specifically determined for the test sample.

$b_{s}=0.9$, the appropriate constant for the calibration sample.

The value of $b$ is calculated by measuring the times of three samples of the material for each of the four porosities. The values of $\sqrt{\varepsilon^{3} T}$ and $\varepsilon$ are plotted and the intersection of the best-fit regression line with the $Y$-axis is $b$. If the correlation coefficient between $\sqrt{\varepsilon^{3} T}$ and $\varepsilon$ is higher than 0.997 , the $\mathrm{b}$ value is accepted and the specific surface area can be calculated. If the correlation 
coefficient is less than 0.997 the data are discarded and a new set of samples is evaluated.

\section{ASPHALT FILM THICKNESS}

Asphalt film thickness is not directly considered for the design of asphalt concrete. However, research has demonstrated that a desirable coat is needed over the aggregate particles to ensure the performance of the asphalt concrete.

A method to calculate the film thickness of an asphalt mix, based on the surface area factors, was developed by Hveem. The following formula is used to calculated the film thickness (Roberts, et. al, 1996):

$$
T_{F}=\frac{V_{b e}}{S A \times M_{s}} \times \rho_{w}
$$

Where:

$\mathrm{T}_{\mathrm{F}}=$ Average Film Thickness, microns;

$V_{\text {be }}=$ Effective volume of asphalt cement (liters)

$\mathrm{SA}=$ Specific surface area of the aggregate $\left(\mathrm{m}^{2} / \mathrm{kg}\right)$

$\mathrm{M}_{\mathrm{s}}=$ Mass of aggregate $(\mathrm{kg})$

$\rho_{\mathrm{w}}=$ Density of water $\left(\mathrm{grams} / \mathrm{cm}^{3}\right)$

Campen et al. (1959) recognized the relationship between voids, aggregate surface area, binder film thickness and stability for dense graded asphalt concrete mixes. A recommendation of an average asphalt film thickness of 6 to 8 microns was needed for flexible and durable asphalt mixtures. Thinner asphalt films results in mixes that are likely to break, crack, and ravel. An $8 \mu \mathrm{m}$ film thickness was also recommended by NCAT researchers (Kandhal et.al, 1998-1).

\section{INFLUENCE OF MINERAL FILLER ON ASPHALT CONCRETE}

Kandhal (1998-2) reviewed several studies which demonstrated that the properties of the asphalt concrete are strongly influenced by the material passing the $0.075 \mathrm{~mm}$ sieve. This material is generally referred to mineral filler. 
Mineral fillers can play a role as filler or as an extender. If the mineral filler acts like an extender it can produce flushing and rutting. The Marshall specifications limit the amount of mineral fillers by applying a maximum filler/asphalt ratio 0.6 to 1.2 based on the optimum asphalt content of the mix. For SuperPave fine gradation mixes, the allowable range is the same. SuperPave increases the allowable range for course gradations to 0.8 to 1.6. The Marshall D/A ratio is computed using the total asphalt content and for SuperPave the effective asphalt content is used. Since $P_{b}>P_{b e}$, the computed D/A for SuperPave mixes will be greater than for Marshall mixes if all other factors are equal.

In order to obtain higher density and strength in asphalt cement mixes it is necessary to add some mineral filler. Its job is to fill the space between the gravel and the sand increasing the density of the mix. Mineral filler also affects the asphalt content because of its surface area. To avoid bleeding of the pavement and lost of stability, it is necessary to cut down the amount of asphalt used (Tunnicliff, 1967).

\section{SUMMARY OF LITERATURE REVIEW}

The review of the literature demonstrate the availability of analytical and experimental methodologies that may potentially improve the mix design methods which rely on the volumetric analysis for establishing the optimum asphalt content. The voids in the mineral aggregate criteria are critical since they initially establish the volume of the effective binder in the mix. However, the current VMA criteria were derived for mixes with natural sands and the questionable assumptions concerning the shape of the aggregate.

The VMA criteria were essentially established by McLeod in research reported in the 1950's. These criteria in a modified form were adopted for the SuperPave specifications. These conclusions were based on computed average asphalt film thickness, defined as the effective volume of asphalt divided by the surface area of the aggregates. Kandhal, et al. (1998-1) used specific surface 
area factors developed by Edwards, which assumed the aggregate particles are smooth sided spheres.

Edwards-Hveem and Craus-Ishai methods to determine specific surface area are based on the same assumption, but the factors obtained are not equal. The reason for this discrepancy is not described in the literature. Craus- Ishai values can be confirmed with calculations. The surface area factors were derived with the assumption that aggregates are spheres with the diameter equal to the size of the sieve through which the aggregate passes. These surface area factors were not experimentally validated. There is evidence from Duriez and Arrambide that the computed surface area factors for sand material finer than $0.075 \mathrm{~mm}$ may be in error by a factor of four. Chapuis and Legare present evidence that the Hveem-Edwards surface area factors are incorrect by a factor of 6 to 10 , depending on mineralogy, for mineral fillers from crushed materials. They also demonstrated that the Blaine air permeability apparatus is a viable method for evaluating surface area of these materials. 


\section{CHAPTER 3 RESEARCH APPROACH}

The objective of this research is to evaluate the effect of aggregate surface area on the selection of the optimum asphalt content. Applying the volumetric analysis for different film thickness for the mix design and values such as VMA, VTM, VFA and fines-asphalt ratio are examined with the purpose to determined the influence of the specific surface area. The analytical method for computing asphalt film thickness requires estimates of specific surface area of the aggregates. The literature review demonstrates a discrepancy between the computed and measured surface area factors for fine materials. Therefore, a laboratory method was used for measuring the surface are of the material finer than $0.15 \mathrm{~mm}$.

The research approach involved obtaining samples of fine materials from various sources throughout the state of West Virginia. The specific surface areas of the samples were evaluated with a Blaine air permeability apparatus. Then using analytical methods set forth by Kandhal et al. (1998-1) the implications of the measured surface area on the film thickness and VMA were evaluated.

\section{SAMPLES TESTED}

The samples used the research were provided by eight asphalt plants which provide asphalt concrete for the West Virginia Division of Highways. The suppliers provided samples of fine aggregate and baghouse fines. The following asphalt plants provided the samples for the research. The specific gravities are presented in Table A.1 in the Appendix A.

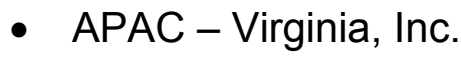

- J.F. Allen Company

- Meadows Stone \& Paving, Inc.

- New Enterprise Stone \& Lime Co. Inc.

- Tri-State Company.

- West Virginia Paving, Inc.

- Southern W.V. Paving. 
The suppliers provided specific gravity for some samples, the ones not provided were measured during the research. The fine aggregate provided by the asphalt plants, were sieved and stored by size. All baghouse fine samples were evaluated for specific gravity using the procedures outlined in Chapter 2

The air permeability apparatus used for the research was limited to material finer than $0.15 \mathrm{~mm}$. Three types of samples were evaluated during the research:

1. Material passing the $0.15 \mathrm{~mm}$ sieve and retained on the $0.075 \mathrm{~mm}$ sieve,

2. Material passing the $0.075 \mathrm{~mm}$ sieve and retained in the pan, and

3. Baghouse fines samples,

\section{THEORETICAL ANALYSIS}

The relationships set forth by Kandhal et al. (1998-1), Equations 2.10 to 2.15, when corrected for absorbed asphalt, can be used either compute the voids in the mineral aggregate for a given film thickness, or to compute the film thickness for a given level of VMA. To compute VMA for given asphalt film thickness, the following equations are used.

The weight of effective binder is based on a desired film thickness and the total surface area of the mix is computed as:

$$
W_{b e}=\left(S A \times T_{b} \times 10^{6}\right) \times\left(G_{b} \times 1000\right)
$$

Equation 3.1 was derived from Equation 2.10.

The percentage of binder absorbed is determined using Equation 2.21 and 2.8.

The weight of the absorbed asphalt is computed as:

$$
W_{b a}=P_{b a} \times W_{s}
$$

The weight of the total binder is the sum of the weights of the effective and the absorbed binder.

$$
W_{b}=W_{b e}+W_{b a}
$$


With the weights determined in Equations 3.1 and 3.2 the volume of the effective and the absorbed binder can be obtained using Equations 3.4 and 3.5.

$$
\begin{gathered}
V_{b a}=\frac{W_{b a}}{G_{b}} \\
V_{b e}=\frac{W_{b e}}{G_{b}}
\end{gathered}
$$

The total volume of the binder is then:

$$
V_{b}=V_{b a}+V_{b e}
$$

The weight of the mix is determined from Equation 3.7 and with this value is possible to calculate the percentage of the total binder and the effective binder using Equations 3.8 and 3.9.

$$
\begin{gathered}
W_{m}=W_{b}+W_{s} \\
P_{b}=\frac{W_{b}}{W_{m}} \\
P_{b e}=\frac{W_{b e}}{W_{m}}
\end{gathered}
$$

Equation 3.9 was the conventional definition of effective binder percent. This is different from the equation suggested by Kandhal which does not have the weight absorbed binder in the denominator.

The bulk volume of the stone is:

$$
V_{s b}=\frac{W_{s}}{G_{s b}}
$$

It is necessary to determine the voidless volume of the mix and the bulk volume of the mix using Equations 3.11 and 3.12.

$$
\begin{gathered}
V_{m m}=V_{b e}+V_{s b} \\
V_{m b}=\frac{V_{s b}+V_{b e}}{1-P_{a i r}}
\end{gathered}
$$


$P_{\text {air }}$ is the percent air voids in the mix express in decimal form.

Equations $3.13,3.14,3.15$ and 3.16 are the parameters need to check mix design VTM, VMA, dust/binder ratio and VFA.

$$
\begin{aligned}
& V T M=\frac{V_{m b}-V_{m m}}{V_{m b}} \times 100 \\
& V M A=\frac{V_{m b}-V_{s b}}{V_{m b}} \times 100 \\
& F / A=\frac{P_{200}}{P_{b e}} \\
& V F A=\frac{V M A-V T M}{V M A} \times 100
\end{aligned}
$$

The following Equations are used to determine the volume percent of the effective binder and volume percent of the total binder, respectively.

$$
\begin{aligned}
& \% V_{b e}=\frac{V_{b e}}{V_{m b}} \times 100 \\
& \% V_{b}=\frac{V_{b}}{V_{m b}} \times 100
\end{aligned}
$$

To demonstrate these equations, an example of a $19 \mathrm{~mm}$ mix design is presented. The assumptions are presented in Table 3.1, and the gradation is given in Table 3.2.

Table 3.3 shows the volumetric analysis using the Equations 3.1 to 3.18 and the Edwards-Hveem surface area factors use by Hveem presented in Table 2.3. The specific surface area was computed with Equation 2.22 and the gradation in Table 3.2. 
TABLE 3.1 ASSUMPTIONS FOR MIX DESIGN

\begin{tabular}{|c|c|}
\hline S.G. of Asphalt & 1.02 \\
\hline $\begin{array}{c}\text { Bulk S.G. of } \\
\text { Aggregate }\end{array}$ & 2.700 \\
\hline $\begin{array}{c}\text { Average Film } \\
\text { Thickness } \mu \mathrm{m}\end{array}$ & 8.00 \\
\hline $\begin{array}{c}\text { Percentage Air } \\
\text { Voids }\end{array}$ & $4 \%$ \\
\hline $\mathrm{G}_{\mathrm{sb}}$ & 2.70 \\
\hline $\mathrm{G}_{\mathrm{sa}}$ & 2.808 \\
\hline $\mathrm{G}_{\mathrm{se}}$ & 2.786 \\
\hline
\end{tabular}

TABLE 3.2 GRADATION FOR A 19 $\mathrm{mm}$ MIX

\begin{tabular}{|c|c|c|}
\cline { 2 - 3 } \multicolumn{1}{c|}{} & \multicolumn{2}{|c|}{ Example gradation } \\
\hline $\begin{array}{c}\text { Sieve } \\
\text { Size, } \\
\mathrm{mm}\end{array}$ & $\begin{array}{c}\% \\
\text { Passing }\end{array}$ & $\begin{array}{c}\% \\
\text { Retained }\end{array}$ \\
\hline 25 & $100.0 \%$ & $0.0 \%$ \\
\hline 19 & $95.0 \%$ & $5.0 \%$ \\
\hline 12.5 & $78.0 \%$ & $17.0 \%$ \\
\hline 9.5 & $66.0 \%$ & $12.0 \%$ \\
\hline 4.75 & $51.0 \%$ & $15.0 \%$ \\
\hline 2.36 & $34.6 \%$ & $16.4 \%$ \\
\hline 1.18 & $25.3 \%$ & $9.3 \%$ \\
\hline 0.6 & $18.7 \%$ & $6.6 \%$ \\
\hline 0.3 & $13.7 \%$ & $5.0 \%$ \\
\hline 0.15 & $9.0 \%$ & $4.7 \%$ \\
\hline 0.075 & $5.0 \%$ & $4.0 \%$ \\
\hline pan & & $5.0 \%$ \\
\hline
\end{tabular}


TABLE 3.3 VOLUMETRIC ANALYSIS FOR MIX DESIGN

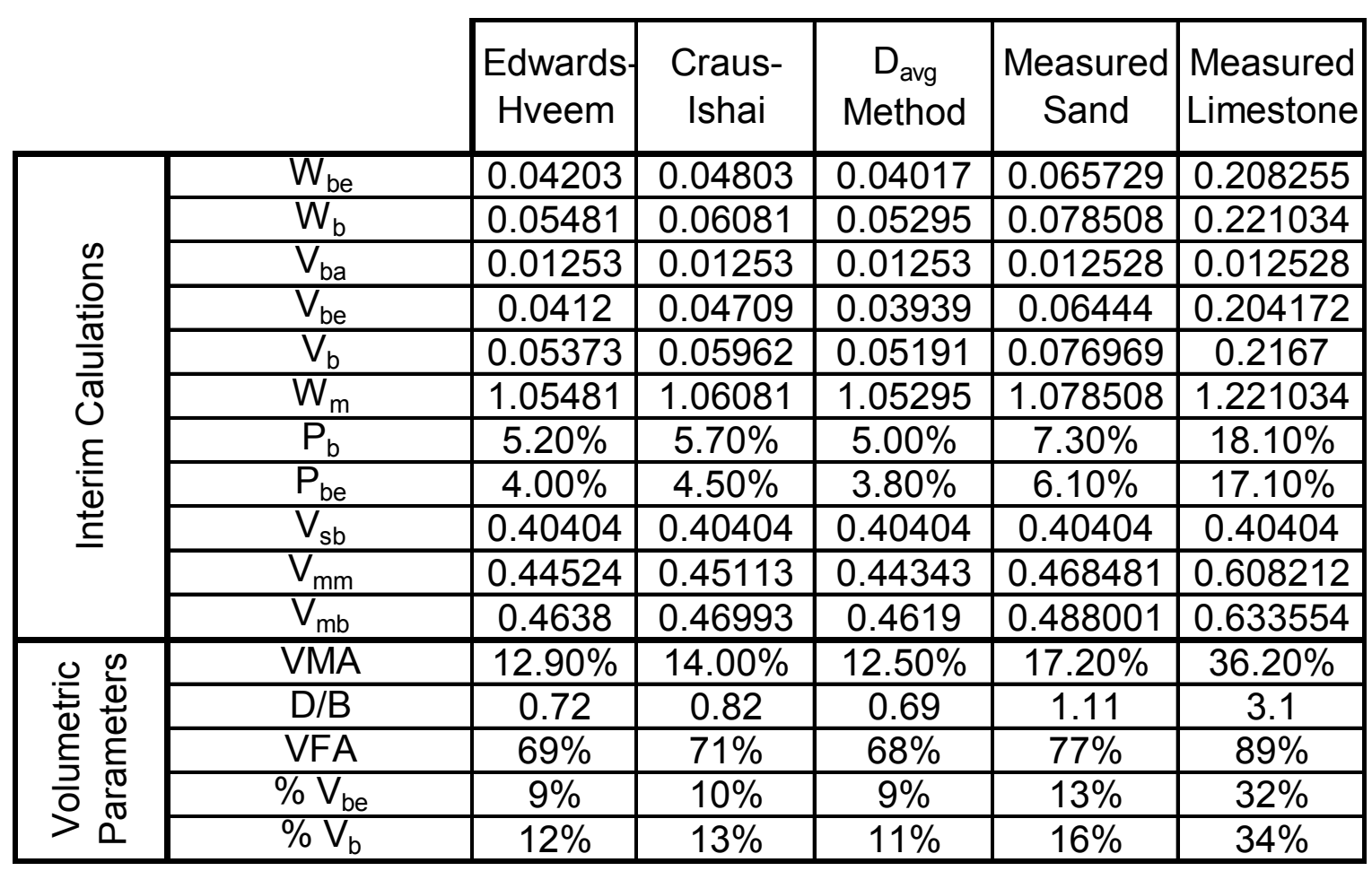

Table 3.3 shows the values of the interim calculations needed to determine the volumetric parameters. The volumetric parameters will help to demonstrate the influence of the specific surface area in the aggregate blend.

\section{EVALUATION OF PARTICLE SIZE}

The Edwards-Hveem formulation for computing surface area, Equation 2.22, uses the total percent passing a sieve multiplied by the surface area factor for the sieve to determine the specific surface area for aggregates with given gradation. For example, from Table 2.3 the Hveem-Edwards surface area factor for the $0.15 \mathrm{~mm}$ sieve is 12.29 , for the gradation in Table 3.2. The computed surface area for the material passing this sieve would be $12.29 \times 0.09=1.11$. This approach appears to be faulty as the surface area factors are computed based on the size of the sieve that the material passes through. This concern gave rise to the need to evaluate the appropriate percent of aggregate use in 
computation of the specific surface area. Chapuis and Legare (1992) recommended using the edge dimension of the sieve that retains the material times the percent material retained on the sieve. However, the dimension of the retained particles are actually larger than this dimension. An alternative method was developed for computing the surface area of the materials coarser than 0.15 $\mathrm{mm}$. The spherical aggregate shape assumption was retained, but the diameter was computed as the average size of the sieve, which retains the material, and the next larger sieve. For example, the diameter of the material retained on the $0.15 \mathrm{~mm}$ sieve was assumed to be $0.5 \times(0.15+0.50)=0.225 \mathrm{~mm}$. The resulting surface area factor is 10.06 . The computed surface area factor was multiplied by the percent material retained on the sieve to determine the surface area. Thus, for this example the surface area of the material retained on the $0.15 \mathrm{~mm}$ sieve is 0.472. This method is termed $D_{\text {avg }}$ in Table 3.3.

A spreadsheet program was developed to compute the volumetric properties using different definitions of the percent aggregate.

\section{GRADATIONS USED IN VOLUMETRIC ANALYSIS}

To demonstrate the sensitivity of the volumetric analysis to aggregate gradation, eight gradations were selected. Two nominal maximum size gradations were evaluated, 9.5 and $19 \mathrm{~mm}$. For each of these, four gradations were defined.

Four $9.5 \mathrm{~mm}$ mix designs were evaluated:

Gradation \#1 -provided by JFA

Gradation \#2 -provided by JFA

Gradation \#3 - provided by JFA

Gradation \#4 - provided by JFA

And, four $19 \mathrm{~mm}$ mix design were evaluated:

Gradation \#1 -provided by Kandhal research.

Gradation \#2 -provided by Vusavi Kanneganti reaserch (2002).

Gradation \#3 - provided by JFA

Gradation \#4 - provided by JFA 
The mixes provided by JFA are gradations used in asphalt concrete mixes prepare by the plant and place in roads in the state of West Virginia.

Table 3.4 and 3.5 gives the percent passing and the percent retained on each sieve for each gradation analyzed. Figures 3.1 and 3.2 graphically display these gradations. The percent passing is used with the Edwards-Hveem and Craus-Ishai surface area factors. The percent retained is needed to compute the surface area per unit mass of the gradations with the surface area factors from $D_{\text {avg }}$ method, measured sand, and the measured limestone.

\section{SUMMARY OF RESEARCH APPROACH}

In order to evaluate the effect of the aggregate specific surface area on asphalt concrete mixtures volumetric properties three steps are required:

1. Measurement of the specific surface area of the materials finer than $0.15 \mathrm{~mm}$.

2. Development of the theoretical analysis procedures for the computing both asphalt film thickness and volumetric properties.

3. Evaluations of the appropriate aggregate gradation parameter for the computing specific surface area. 
TABLE 3.4 9.5 mm MIX DESIGNS GRADATIONS FOR ASPHALT CONCRETE

\begin{tabular}{|c|c|c|c|c|c|c|c|c|}
\hline \multirow{2}{*}{$\begin{array}{c}\text { Sieve } \\
\text { Size, } \\
\mathrm{mm}\end{array}$} & $\begin{array}{c}|c| \\
\text { Passing }\end{array}$ & $\begin{array}{c}\% \\
\text { Retained }\end{array}$ & $\begin{array}{c}\% \\
\text { Passing }\end{array}$ & $\begin{array}{c}\text { \% } \\
\text { Retained }\end{array}$ & $\begin{array}{c}\% \\
\text { Passing }\end{array}$ & $\begin{array}{c}\% \\
\text { Retained }\end{array}$ & $\begin{array}{c}\% \\
\text { Passing }\end{array}$ & $\begin{array}{c}\% \\
\text { Retained }\end{array}$ \\
\hline 25 & $100.0 \%$ & $0.0 \%$ & $100.0 \%$ & $0.0 \%$ & $100.0 \%$ & $0.0 \%$ & $100.0 \%$ & $0.0 \%$ \\
\hline 19 & $100.0 \%$ & $0.0 \%$ & $100.0 \%$ & $0.0 \%$ & $100.0 \%$ & $0.0 \%$ & $100.0 \%$ & $0.0 \%$ \\
\hline 12.5 & $100.0 \%$ & $0.0 \%$ & $100.0 \%$ & $0.0 \%$ & $100.0 \%$ & $0.0 \%$ & $100.0 \%$ & $0.0 \%$ \\
\hline 9.5 & $98.0 \%$ & $2.0 \%$ & $95.0 \%$ & $5.0 \%$ & $97.0 \%$ & $3.0 \%$ & $98.0 \%$ & $2.0 \%$ \\
\hline 4.75 & $56.0 \%$ & $42.0 \%$ & $57.0 \%$ & $38.0 \%$ & $58.0 \%$ & $39.0 \%$ & $69.0 \%$ & $29.0 \%$ \\
\hline 2.36 & $38.0 \%$ & $18.0 \%$ & $44.0 \%$ & $13.0 \%$ & $37.0 \%$ & $21.0 \%$ & $42.0 \%$ & $27.0 \%$ \\
\hline 1.18 & $25.0 \%$ & $13.0 \%$ & $27.0 \%$ & $17.0 \%$ & $25.0 \%$ & $12.0 \%$ & $25.0 \%$ & $17.0 \%$ \\
\hline 0.6 & $20.0 \%$ & $5.0 \%$ & $15.0 \%$ & $12.0 \%$ & $15.0 \%$ & $10.0 \%$ & $16.0 \%$ & $9.0 \%$ \\
\hline 0.3 & $11.0 \%$ & $9.0 \%$ & $8.0 \%$ & $7.0 \%$ & $9.0 \%$ & $6.0 \%$ & $10.0 \%$ & $6.0 \%$ \\
\hline 0.15 & $6.0 \%$ & $5.0 \%$ & $7.2 \%$ & $0.8 \%$ & $6.0 \%$ & $3.0 \%$ & $6.8 \%$ & $3.2 \%$ \\
\hline 0.075 & $5.5 \%$ & $0.5 \%$ & $5.0 \%$ & $2.2 \%$ & $4.2 \%$ & $1.8 \%$ & $5.1 \%$ & $1.7 \%$ \\
\hline pan & & $5.5 \%$ & & $5.0 \%$ & & $4.2 \%$ & & $5.1 \%$ \\
\hline
\end{tabular}

FIGURE 3.1 GRADATIONS FOR NMAS $9.5 \mathrm{~mm}$

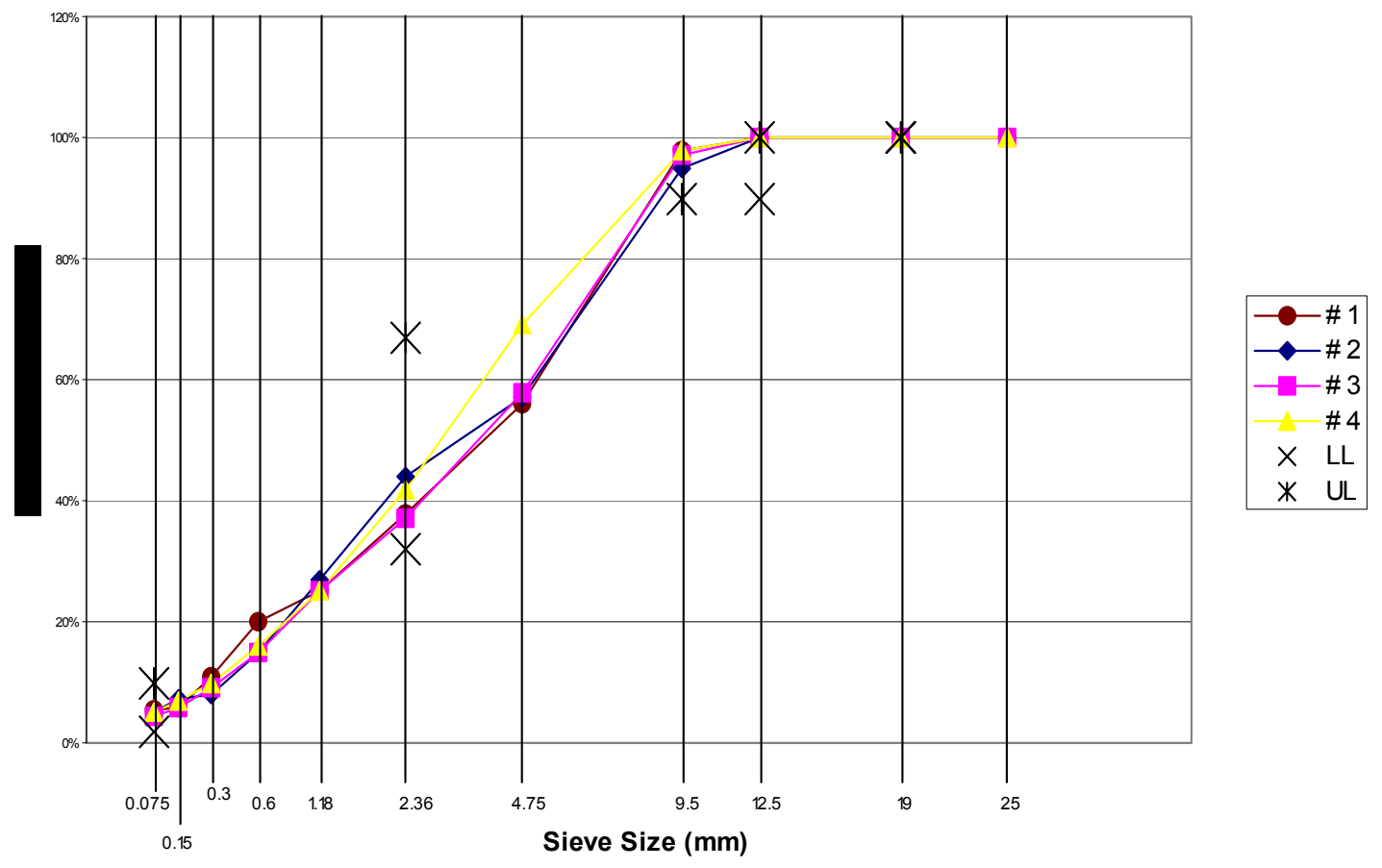


TABLE $3.519 \mathrm{~mm}$ MIX DESIGNS GRADATIONS FOR ASPHALT CONCRETE

\begin{tabular}{|c|c|c|c|c|c|c|c|c|}
\hline \multirow{2}{*}{$\begin{array}{c}\text { Sieve } \\
\text { Size } \\
\text { mm }\end{array}$} & $\begin{array}{c}\text { \% } \\
\text { Passing }\end{array}$ & $\begin{array}{c}\% \\
\text { Retained }\end{array}$ & $\begin{array}{c}\% \\
\text { Passing }\end{array}$ & $\begin{array}{c}\% \\
\text { Retained }\end{array}$ & $\begin{array}{c}\% \\
\text { Passing }\end{array}$ & $\begin{array}{c}\% \\
\text { Retained }\end{array}$ & $\begin{array}{c}\% \\
\text { Passing }\end{array}$ & $\begin{array}{c}\% \\
\text { Retained }\end{array}$ \\
\hline 25 & $100.0 \%$ & $0.0 \%$ & $100.0 \%$ & $0.0 \%$ & $100.0 \%$ & $0.0 \%$ & $100.0 \%$ & $0.0 \%$ \\
\hline 19 & $95.0 \%$ & $5.0 \%$ & $92.0 \%$ & $8.0 \%$ & $95.0 \%$ & $5.0 \%$ & $92.0 \%$ & $8.0 \%$ \\
\hline 12.5 & $78.0 \%$ & $17.0 \%$ & $75.0 \%$ & $17.0 \%$ & $84.0 \%$ & $11.0 \%$ & $73.0 \%$ & $19.0 \%$ \\
\hline 9.5 & $66.0 \%$ & $12.0 \%$ & $67.0 \%$ & $8.0 \%$ & $72.0 \%$ & $12.0 \%$ & $65.0 \%$ & $8.0 \%$ \\
\hline 4.75 & $51.0 \%$ & $15.0 \%$ & $58.0 \%$ & $9.0 \%$ & $49.0 \%$ & $23.0 \%$ & $53.0 \%$ & $12.0 \%$ \\
\hline 2.36 & $34.6 \%$ & $16.4 \%$ & $39.0 \%$ & $19.0 \%$ & $29.0 \%$ & $20.0 \%$ & $35.0 \%$ & $18.0 \%$ \\
\hline 1.18 & $25.3 \%$ & $9.3 \%$ & $28.0 \%$ & $11.0 \%$ & $14.0 \%$ & $15.0 \%$ & $21.0 \%$ & $14.0 \%$ \\
\hline 0.6 & $18.7 \%$ & $6.6 \%$ & $20.0 \%$ & $8.0 \%$ & $9.0 \%$ & $5.0 \%$ & $12.0 \%$ & $9.0 \%$ \\
\hline 0.3 & $13.7 \%$ & $5.0 \%$ & $17.0 \%$ & $3.0 \%$ & $8.0 \%$ & $1.0 \%$ & $8.0 \%$ & $4.0 \%$ \\
\hline 0.15 & $9.0 \%$ & $4.7 \%$ & $15.0 \%$ & $2.0 \%$ & $6.0 \%$ & $2.0 \%$ & $5.0 \%$ & $3.0 \%$ \\
\hline 0.08 & $5.0 \%$ & $4.0 \%$ & $4.0 \%$ & $11.0 \%$ & $5.0 \%$ & $1.0 \%$ & $3.9 \%$ & $1.1 \%$ \\
\hline pan & & $5.0 \%$ & & $4.0 \%$ & & $5.0 \%$ & & $3.9 \%$ \\
\hline
\end{tabular}

FIGURE 3.2 GRADATIONS FOR NMAS 19 mm

$19 \mathrm{~mm}$ Gradations

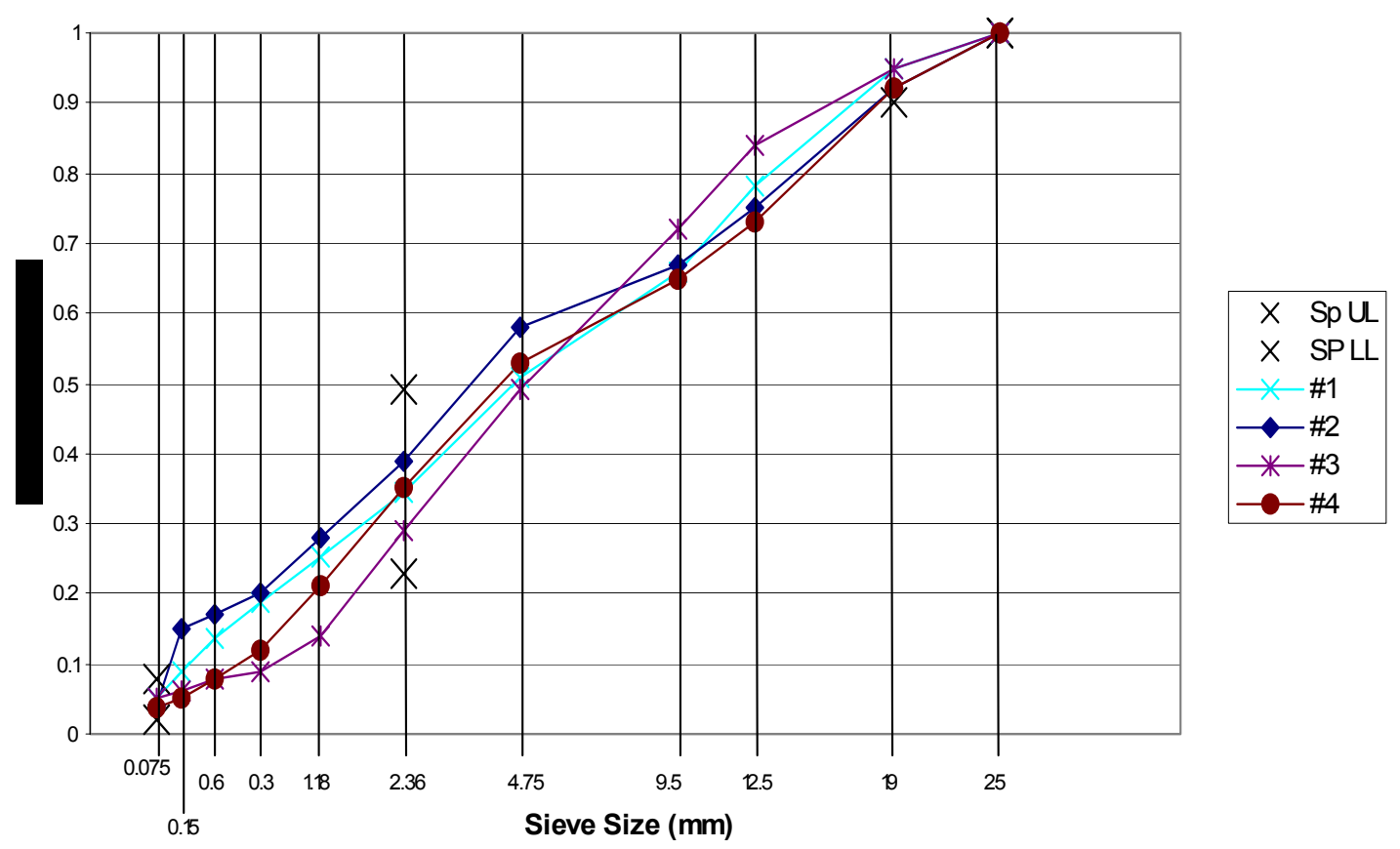




\section{CHAPTER 4 DATA COLLECTION AND ANALYSIS}

As shown in Table A.1 samples of fine aggregate material were obtained from nine vendors who supply product to the WVDOT. Six fine aggregate samples were obtained to evaluate surface area and specific gravity. In addition, nine samples of baghouse material were obtained. The fine aggregate samples were sieved to capture the material passing the $0.15 \mathrm{~mm}$ sieve and retained in the $0.075 \mathrm{~mm}$ sieve, and the pan material. The baghouse material was not sieve prior to evaluation.

\section{SPECIFIC GRAVITY}

The specific gravity of the aggregates is required for the determinations of specific and volumetric parameters. The specific gravity of the fine material were supplied by the vendors in some cases and measure for others. In all cases the specific gravity of the supplied baghouse fines were measured, the data for specific gravity evaluation are presented in Appendix $A$ and the results are summarized in Tables 4.1 and 4.2 .

TABLE 4.1 AVERAGE SPECIFIC SURFACE AREAS FOR EACH SAMPLE

\begin{tabular}{|c|c|c|c|}
\hline Source & S.G. & $\begin{array}{c}\text { Average } \\
\text { SA Pan } \\
\text { (m2/kg) }\end{array}$ & $\begin{array}{c}\text { Average } \\
\text { S.A. \# 200 } \\
\text { (m2/kg) }\end{array}$ \\
\hline Summersville & 2.575 & 457.64 & 24.84 \\
\hline Beaver Boxley (A) & 2.667 & 434.77 & 21.48 \\
\hline Beaver Boxley (B) & 2.620 & 288.87 & 13.90 \\
\hline APAC Sand & 2.684 & 478.01 & 30.69 \\
\hline APAC \# 10 & 2.603 & 437.09 & 18.45 \\
\hline New Enterprise & 2.523 & 614.77 & 11.18 \\
\hline Natural Sand & 2.522 & 118.49 & 7.26 \\
\hline \multicolumn{2}{|c|}{ Edwards-Hveem } & 32.77 & 12.29 \\
\hline \multicolumn{2}{|c|}{ Craus-Ishai } & 30.19 & 15.09 \\
\hline \multicolumn{2}{|c|}{}
\end{tabular}


TABLE 4.2 AVERAGE SPECIFIC SURFACE AREA FOR THE BAGHOUSE FINES

\begin{tabular}{|l|c|c|}
\hline Source & S.G. & $\begin{array}{c}\text { Average } \\
\text { S.A. } \\
\text { Baghouse } \\
\text { (m2/kg) }\end{array}$ \\
\hline Summersville & 2.723 & 809.86 \\
\hline Gasaway & 2.712 & 571.12 \\
\hline Beaver Boxley & 2.672 & 1187.85 \\
\hline $\begin{array}{l}\text { Beaver Boxley } \\
\text { fam }\end{array}$ & 2.687 & 952.68 \\
\hline APAC Sand & 2.707 & 744.71 \\
\hline JFK & 2.588 & 747.43 \\
\hline New Enterprise & 2.706 & 668.66 \\
\hline W.V. Paving & 2.686 & 618.51 \\
\hline Tri-State & 2.730 & 583.05 \\
\hline Average & & 764.84 \\
\hline
\end{tabular}

\section{MEASURED SPECIFIC SURFACE AREA}

The surface area of each sample was evaluated with the Blaine air permeability apparatus. Samples were prepared and tested using the procedures outlined in Chapter 2. The data from each test were recorded of the form shown in Figure 4.1 and the results presented in the Appendix $B$

Part $A$ of the form is the identification and calibration constants for the air permeability apparatus. Part B shows the specific gravity of the material used and the temperature at the time of the test. 
FIGURE 4.1 DATA SHEET FOR AIR PERMEABILITY APPARATUS

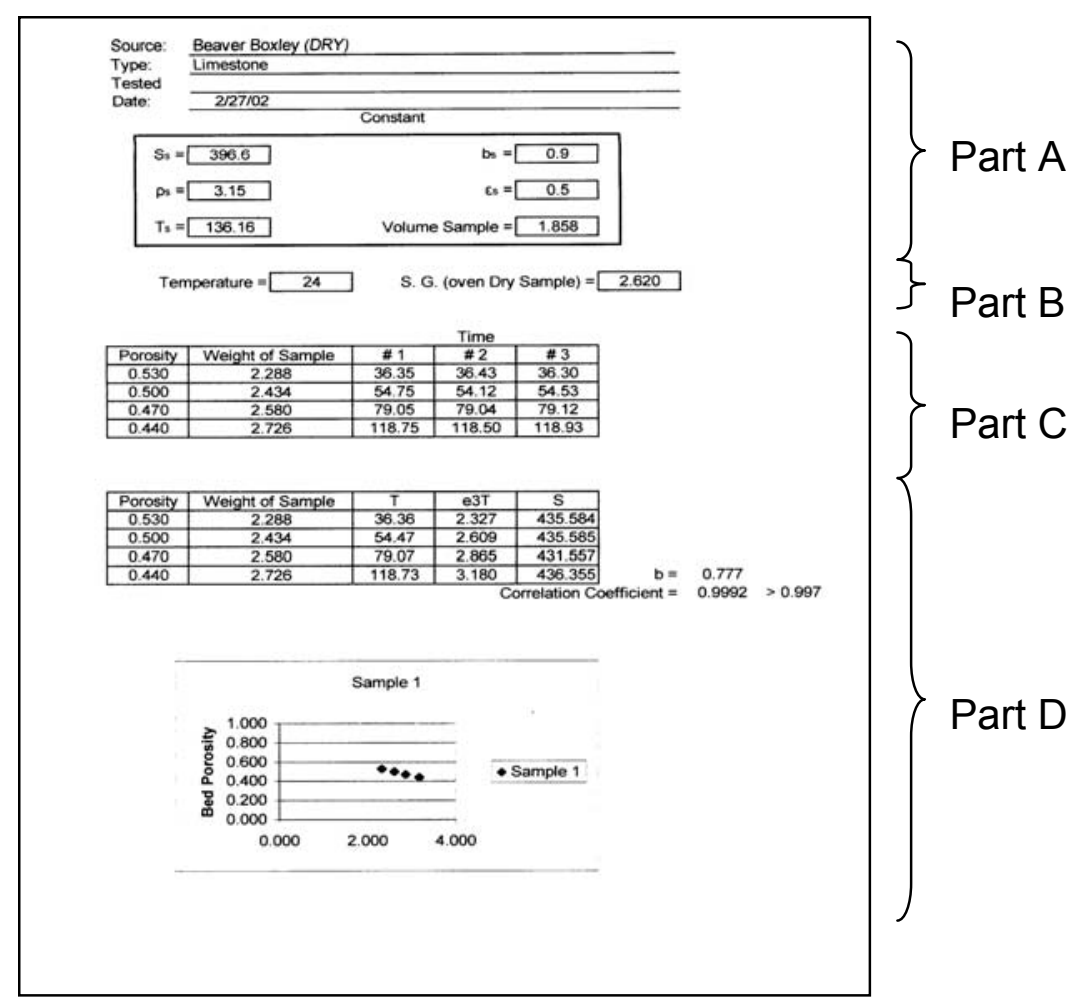

Part $\mathrm{C}$ shows the times measured for each porosity level. For the pan and the baghouse material three times are recorded for each porosity. For the material retained in the $0.075 \mathrm{~mm}$ sieve six times are measured for each porosity because the times measured are small and in order to have a better precision, six times were recorded.

On part $\mathrm{D}$ of the form, the computed results are recorded. The computed values are the average time at each porosity level, the bed porosity constant, b, and the specific surface area, S. The bed porosity, $b$, is the intercept of a regression Equation computed for a porosity versus porosity-fine term, the porosity-time term is $\sqrt{\varepsilon^{3} T}$. The process is illustrated in Figure 4.2. Once the bed porosity constant for the sample is known, the specific surface area is computed for each porosity level. The average specific area for the material is used in the film thickness and the volumetric analysis. The average surface 
FIGURE 4.2 METHOD FOR THE CALCULATION OF CONSTANT b

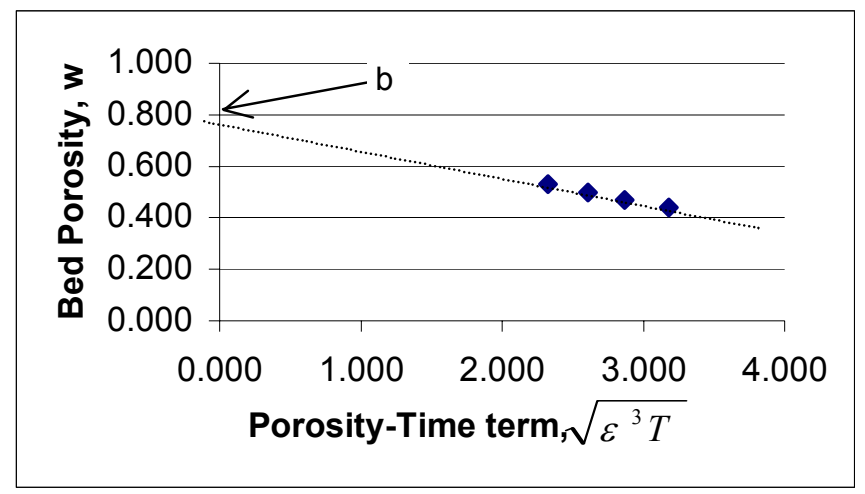

areas, along with the specific gravity, are given in Tables 4.1 and 4.2 for the mineral aggregate and the baghouse fine materials, respectively. The results for all the tests are presented in the Appendix $B, C$ and $D$ for the $0.15-0.075 \mathrm{~mm}$ samples, pan, and baghouse fines respectively.

The Edwards-Hveem surface area factors for the $0.075 \mathrm{~mm}$ and the pan material were 12.25 and $32.77 \mathrm{~m}^{2} / \mathrm{kg}$, respectively. The corresponding factors for the natural sand sample were 7.26 and $118.49 \mathrm{~m}^{2} / \mathrm{kg}$. As shown by Equation 2.24, the Duriez-Arrambide factor for material finer than $80 \mu \mathrm{m}$ is 135 , which is a reasonable agreement with the value measured during this research.

This demonstrates a considerable difference between the factors estimated based on the aggregate shape and the sieve size, and the measured surface area factors. However, the results for the crushed limestone mineral filler show even greater discrepancy.

The surface area for the limestone pan material ranged from 289 to 615 , with an average of $452 \mathrm{~m}^{2} / \mathrm{kg}$. Chapuis and Legare (1992) values for surface area were 325 and $263 \mathrm{~m}^{2} / \mathrm{kg}$ for the computed and measured methods respectively. These values compare favorably with the minimum values measured during this research.

The surface area factor for the material retained in the $0.075 \mathrm{~mm}$ sieve ranged from 11 to 31 , with an average $20 \mathrm{~m}^{2} / \mathrm{kg}$. There are no values in the literature to compare to these values. 
The surface area of the baghouse material is greater than the pan material. The range of baghouse material surface area was 571 to 1188 , with and average of $765 \mathrm{~m}^{2} / \mathrm{kg}$.

\section{ANALYSIS CASES}

Using the volumetric analysis explained in Chapters 2 and 3 , eight aggregate gradations were studied. Four of these gradations were $19 \mathrm{~mm}$ mixes and the other four were $9.5 \mathrm{~mm}$ mixes. These gradations are presented in Tables 3.4 and 3.5. Five volumetric analysis were made based on alternative methods for computing the aggregate surface area:

1. - Edwards-Hveem.

2. - Surface area factors computed with the Craus-Ishai method.

3. - Surface area factor using the average diameter of two sieves, $D_{\text {avg }}$ method

4. - Measured natural sand, and

5. - Measured limestone.

The Edwards-Hveem values are based on the diameter of the aggregate that is equivalent to the size or the opening of the sieve. These values represent the state of the art in the industry.

Surface area factors computed with the Craus-Ishai method are values obtained using Equation 2.22 (Craus and Ishai 1977). It is assumed that all particles have a sphere or a cube form with $D$ being the diameter or length of the edge and $\rho$ is the density of the aggregate in $\mathrm{kg} / \mathrm{m}^{3}$.

For the surface area factor using the average of two sieves also uses Equation 2.19. The difference between these two factors is the diameter used to compute surface area. For the first one the diameter is equal to the size of the sieve the material passes through. The alternative is to use the average dimension of the passing sieve and the retaining sieve.

The values of the measured sand are the values of the natural sand obtained using the Blaine air permeability apparatus. The measured limestone value is the average of all limestone evaluated with the Blaine air permeability 
apparatus. The $D_{\text {avg }}$ method was used for computing the surface area factors for aggregates larger than $0.15 \mathrm{~mm}$ during the analysis of the measured natural sand and limestone fine material.

All the surface area factors for the five types of analysis are show in the Table 4.3. For Edwards-Hveen and Craus-Ishai methods in Table 4.3 the surface area per unit mass for an aggregate blend is determined by summing the product of the surface area factor times the percent material passing each sieve, Equation 2.22. For $\mathrm{D}_{\text {avg }}$, Measured Sand and Measured Limestone surface area factors are multiplied by the percent retained on each sieve, then summed to determine the total specific surface area.

\section{EFFECT OF AGGREGATE SIZE ON TOTAL SURFACE AREA}

One of the assertions in the literature, which is supported by logic, is that the fine material is dominant contributor to the total surface area of an aggregate blend. However, the specific contribution of each aggregate size has not been documented. Figures 4.3 to 4.7 show the contribution of the different sieve sizes to the total surface area of an aggregate blend. For this analysis, the gradation defined by Kandhal (1998-1) was used. The terms course $(61 \%)$, fine $(34 \%)$, and pan (5\%) represent material retained on the $0.15 \mathrm{~mm}$, passing the $0.15 \mathrm{~mm}$ and retained on the $0.075 \mathrm{~mm}$ sieve, and the passing the $0.075 \mathrm{~mm}$ respectively. Depending on the surface area factor method used, the contribution of the fine range from $30 \%$ for the Edwards-Hveem approach to $79 \%$ for the measured limestone surface area factors. The contribution of the material passing the $0.075 \mathrm{~mm}$ sieve contributes $62 \%$ to 8 percent of the surface area.

The material retained on the $0.15 \mathrm{~mm}$ sieve only contributes in a range of $7 \%$ for the Edwards-Hveem approach to $0.23 \%$ for the measured limestone approach with respect to the total surface area of the aggregate blend. Hence, the assertion that the surface area of the fine materials dominates the total surface area is correct, this validates the approach used in this research to use computed 
TABLE 4.3 SURFACE AREA FACTORS USED FOR THE VOLUMETRIC ANALYSIS

\begin{tabular}{|c|c|c|c|c|c|}
\hline $\begin{array}{c}\text { Sieve } \\
\text { Size, } \\
\mathrm{mm}\end{array}$ & $\begin{array}{l}\text { Edwards- } \\
\text { Hveem } \\
\text { (2) }\end{array}$ & $\begin{array}{l}\text { Craus- } \\
\text { Ishai } \\
\text { (2) }\end{array}$ & $\begin{array}{l}D_{\text {avg }} \\
\text { method } \\
\text { (3) }\end{array}$ & $\begin{array}{c}\text { Measured } \\
\text { Sand } \\
(3,4)\end{array}$ & $\begin{array}{c}\text { Measured } \\
\text { Limestone } \\
(3,4)\end{array}$ \\
\hline 25.0 & 0.41 & 0.09 & 0.073 & & \\
\hline 19.0 & & 0.12 & 0.10 & & \\
\hline 12.5 & & 0.18 & 0.14 & & \\
\hline 9.5 & & 0.24 & 0.21 & & \\
\hline 4.75 & 0.41 & 0.48 & 0.32 & & \\
\hline 2.36 & 0.82 & 0.96 & 0.64 & & \\
\hline 1.18 & 1.64 & 1.92 & 1.28 & & \\
\hline 0.60 & 2.87 & 3.77 & 2.54 & & \\
\hline 0.30 & 6.14 & 7.55 & 5.03 & & \\
\hline 0.15 & 12.29 & 15.09 & 10.06 & & \\
\hline 0.075 & 32.77 & 30.19 & 20.13 & 7.26 & 21.48 \\
\hline pan & & & 60.38 & 118.49 & 434.77 \\
\hline
\end{tabular}

Notes:

1. An aggregate bulk specific gravity of 2.65 was assumed because Edwards-Hveem and Craus-Ishai methods use this value to compute the surface area factors.

2. Uses the percentage passing each sieve in order to determine the surface area per unit mass for an aggregate blend.

3. Uses the percentage retained in each sieve.

4. The $D_{\text {avg }}$ surface area factors were used for material greater than $0.15 \mathrm{~mm}$ for the measured natural sand and the limestone analysis. 
Figure 4.3 Contribution of Size Material to Surface Area. Gradation \#1 NMAS 19MM. Edwards-Hveem.

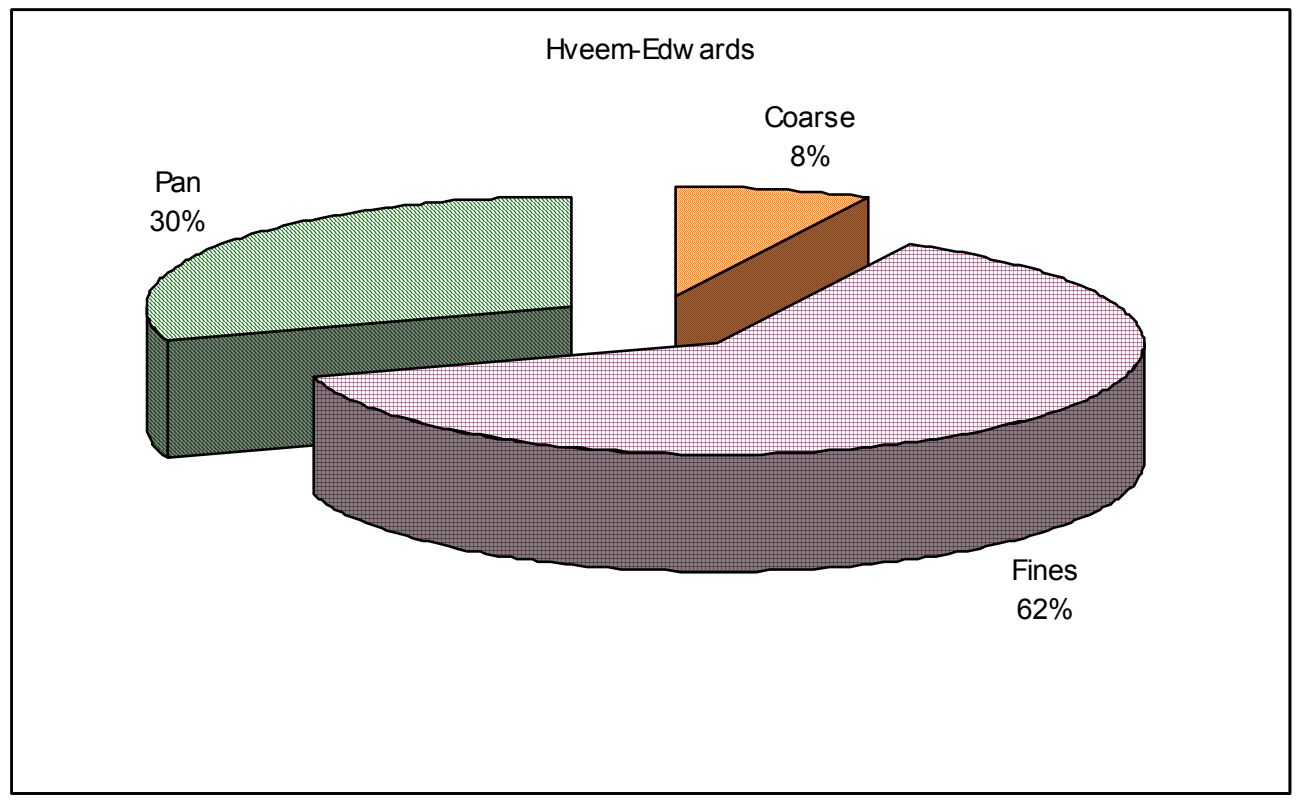

FIGURE 4.4 CONTRIBUTION OF SIZE MATERIAL TO SURFACE AREA. GRADATION \#1 NMAS $19 \mathrm{~mm}$. CRAUS-ISHAI.

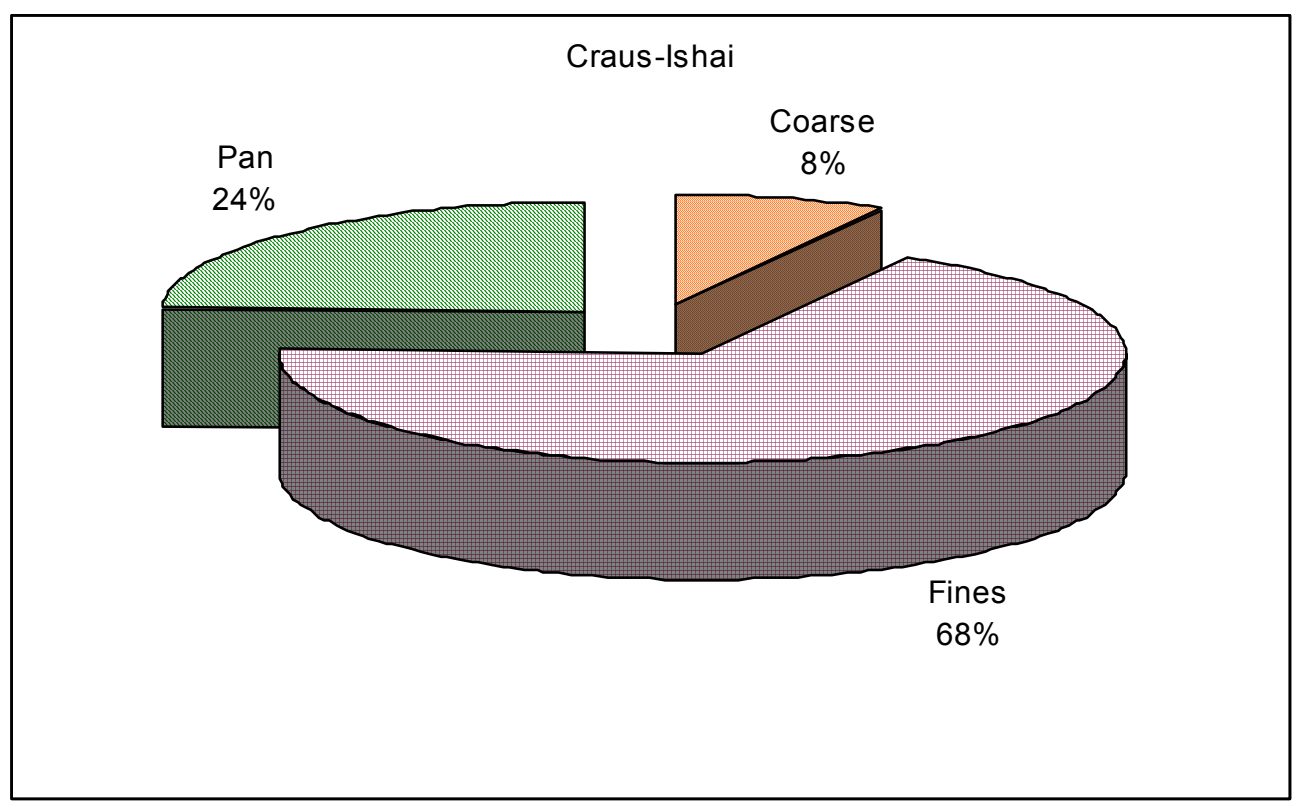


FIGURE 4.5 CONTRIBUTION OF SIZE TO MATERIAL TO SURFACE AREA. GRADATION \#1 NMAS $19 \mathrm{~mm}$. D AVG METHOD

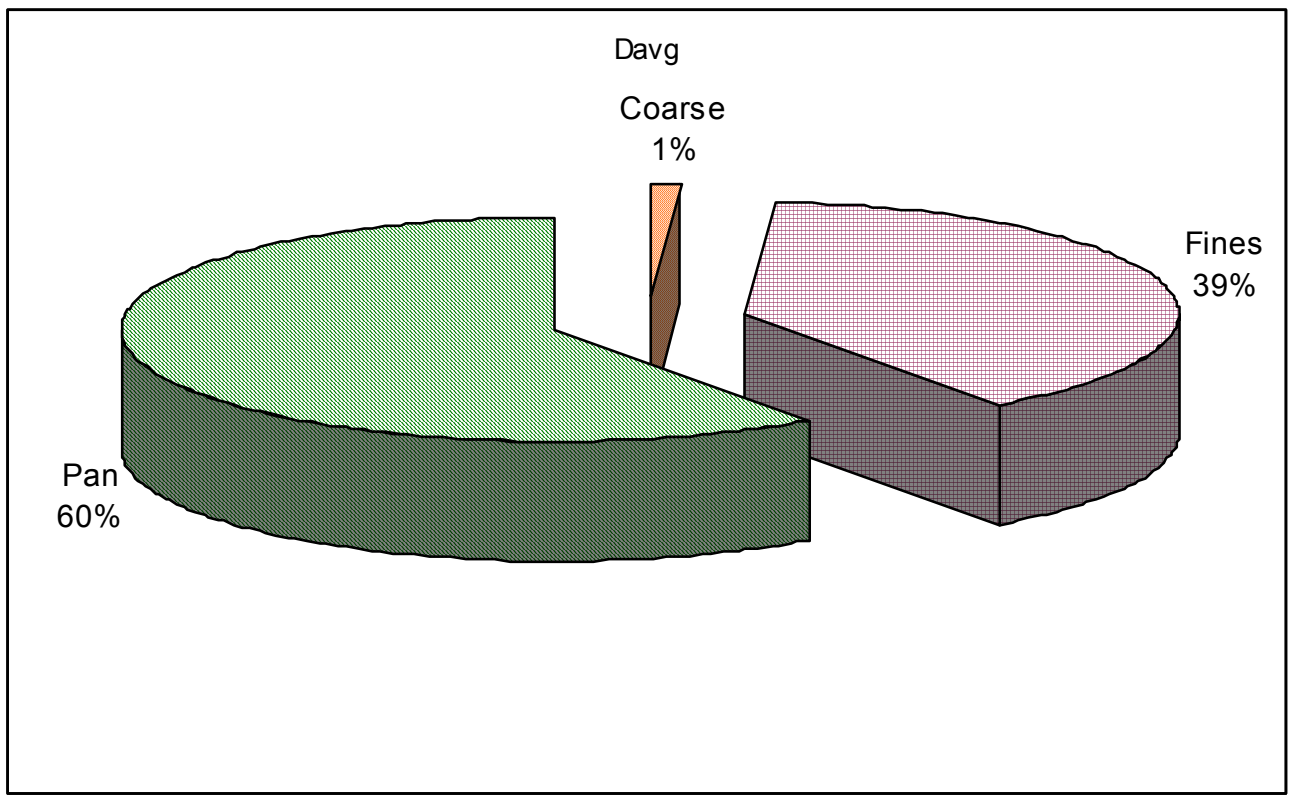

FIGURE 4.6 CONTRIBUTION OF SIZE TO MATERIAL TO SURFACE AREA. GRADATION \#1 MNAS 19 mm. NATURAL SAND

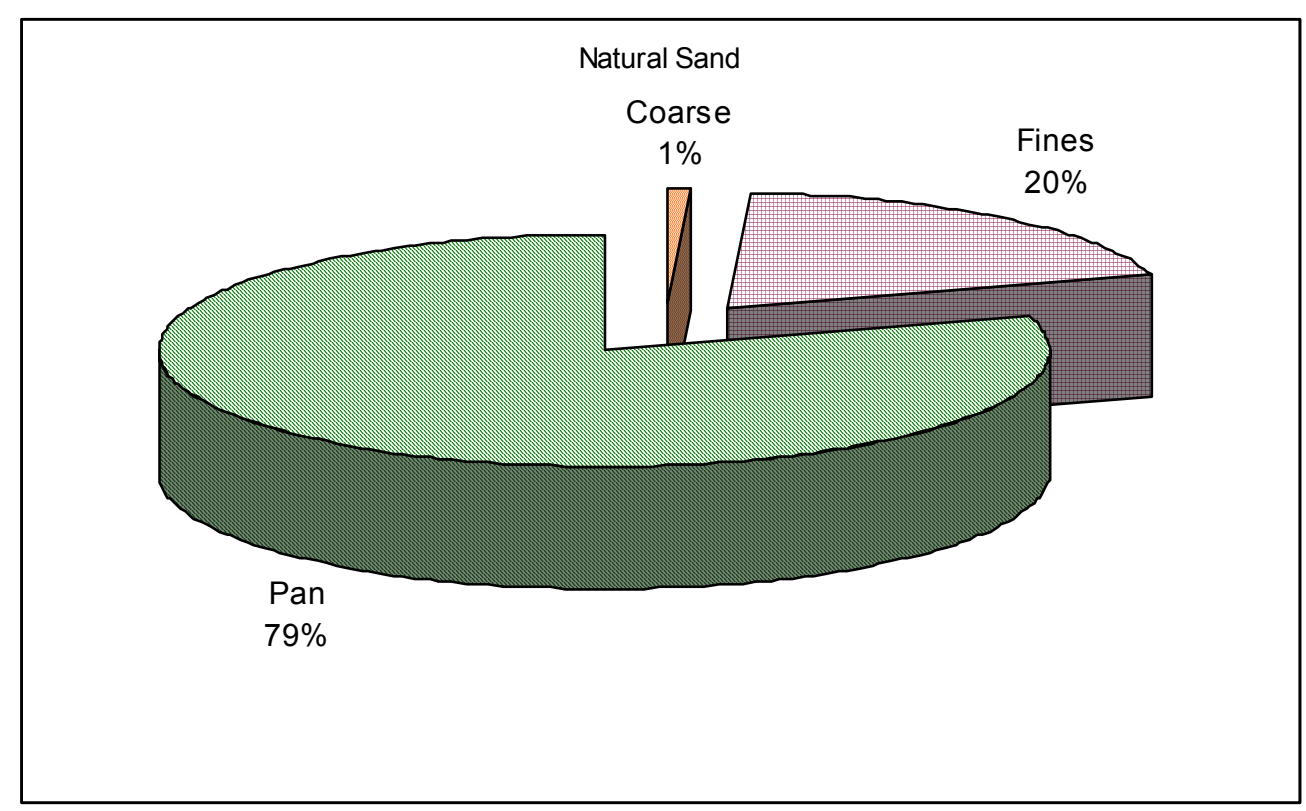


FIGURE 4.7 CONTRIBUTION OF SIZE MATERIAL TO SURFACE AREA GRADATION \#1 NMAS $19 \mathrm{~mm}$. LIMESTONE MATERIAL.

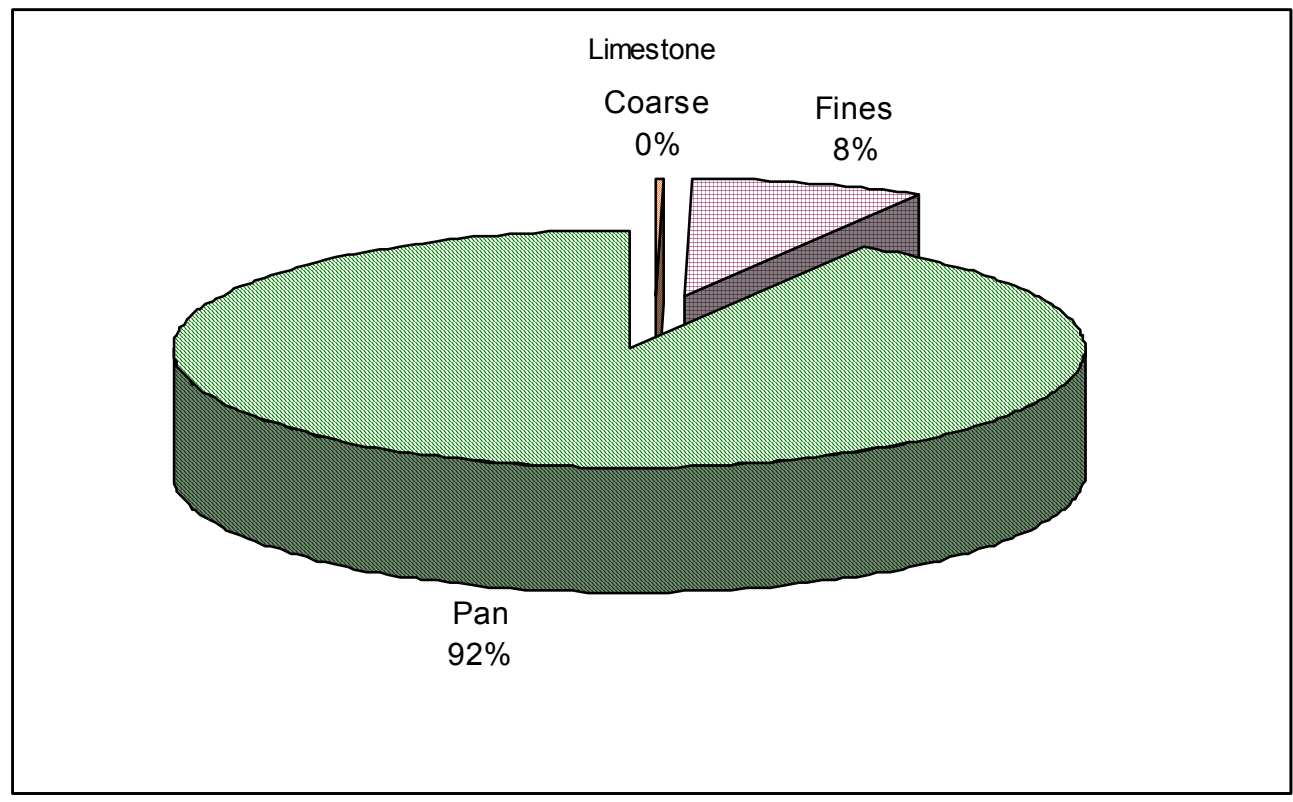

values for the materials retained on the $0.15 \mathrm{~mm}$ sieve. Furthermore, the percent contribution of the materials finer than $0.15 \mathrm{~mm}$ is sensitive to the method used for estimating total surface area. Since the measured surface areas are much greater than the Edwards-Hveem values, their contribution to total surface area dominates is much greater than previously recognized.

\section{VOLUMETRIC PARAMETERS}

In Appendix E, Tables E.1 through E.8 present the volumetric analysis for the eight gradations evaluated. Each table presents information for the five different techniques for computing surface area and for five asphalt film thickness. All calculations were performed assuming 4.0 percent air voids.McLeod (1959) recommended asphalt concrete mixtures have a minimum effective binder content of 10 percent by volume, which with 4 percent air voids, would yield a VMA of 14 percent. McLeod worked with $3 / 4$ inch $(19 \mathrm{~mm}$ ) maximum size aggregate. Kandhal's (1998-1) analysis determined that 
MacLeod's approach would produce an $8 \mu \mathrm{m}$ asphalt film; Table 4.4 shows that for a $3 / 4$ in $(19 \mathrm{~mm})$ nominal maximum aggregate size (NMAS), an asphalt film thickness of $8 \mu \mathrm{m}$ will have an effective asphalt content of 10 percent by volume and a VMA of 14.1 percent. This mix design would meet all the Marshall and SuperPave mix design criteria.

The sensitivity of the volumetric criteria to the aggregate gradation is also demonstrated in Table E.8. Only gradations 1 and 2 for the $19 \mathrm{~mm}$ nominal maximum aggregate size pass all volumetric criteria. The other $19 \mathrm{~mm}$ NMAS and the $9.5 \mathrm{~mm}$ NMAS aggregates do not meet the VMA criteria of a minimum of 13 and 15 percent respectively, examination of Tables E.1 through E.4 show that only gradation 4 has acceptable VMA at $10 \mu \mathrm{m}$ asphalt film thickness. The other gradations have VMA ranging from 14.2 to 14.9 percent. The $19 \mathrm{~mm}$ gradations 3 and 4 have acceptable VMA values if the asphalt film thickness is $10 \mathrm{~mm}$.

TABLE 4.4 SUMMARY OF THE VOLUMETRIC PROPERTIES FOR 8 mm FILM THICKNESS, EDWARDS-HVEEM SURFACE AREA FACTORS.

\begin{tabular}{|l|c|c|c|c|c|}
\hline NMAS & Gradation & $\% \mathrm{~V}_{\text {be }}$ & \multicolumn{1}{l|}{ VMA } & \multicolumn{1}{l|}{ VFA } & \multicolumn{1}{l|}{ D/B } \\
\hline \multirow{4}{*}{$9.5 \mathrm{~mm}$} & 1 & 9 & 12.9 & 69 & 0.72 \\
\cline { 2 - 6 } & 2 & 9 & 12.9 & 69 & 0.76 \\
\cline { 2 - 6 } & 3 & 8 & 12.3 & 68 & 0.83 \\
\hline \multirow{3}{*}{$19 \mathrm{~mm}$} & 4 & 9 & 13.1 & 69 & 0.76 \\
\cline { 2 - 6 } & 1 & 10 & 14.1 & 72 & 0.84 \\
\cline { 2 - 6 } & 2 & 11 & 15.2 & 74 & 1.19 \\
\cline { 2 - 6 } & 4 & 8 & 11.7 & 66 & 0.66 \\
\hline
\end{tabular}


Comparison of the $D_{\text {avg }}$ method for computing surface area the EdwardsHveem and Craus-Ishai methods demonstrates the volumetric parameters are similar. VMA and VFA are consistently lower with the $D_{\text {avg }}$ method as compared to the other two methods. In several cases, mixes that would be identified as acceptable with the Edwards-Hveem and Craus-Ishai methods would fail criteria with the $D_{\text {avg }}$ method of analysis. This does not necessarily indicate the mixes would not perform well. If the analysis method were changed, the criteria may need to be adjusted.

Comparison of the measured natural sand analysis with the EdwardsHveem method shows the volumetric parameters are higher with the measured surface areas. For the $9.5 \mathrm{~mm}$ NMAS gradation 1, Table E.1, with $8 \mu \mathrm{m}$ asphalt film thickness, the VMA decreases to $12.5 \%$ compared to $12.9 \%$ with the Edwards-Hveem method. The VFA increases to $72 \%$ compared to $69 \%$. These values of volumetric parameters are within the realm of reasonable expectations. However, the increase in volumetric parameters is produced at the expense of increased asphalt content. Using the measured sand surface area factors, 7.3 percent asphalt is required to produce an $8 \mu \mathrm{m}$ asphalt film thickness, compared to $5.2 \%$ using Edwards-Hveem surface area factors. It is expected that 7.3 percent asphalt would be unacceptable. However, if the asphalt film thickness is reduced to $6 \mu \mathrm{m}$, the asphalt requirement would be 5.8 percent. The VMA would be 14.3 and the VFA would be $72 \%$. The VFA meets current criteria, but VMA is less than the current criteria of 15 percent. Thus, the measured natural sand surface area factors would alter the current expectation and criteria for an acceptable mix. However, these adjustments would reflect an incremental change in the design, method rather than a major alteration.

As demonstrated in Table 4.3, the surface area factors measured for the limestone pan material are approximately 15 times greater than the EdwardsHveem and the Craus-Ishai factors. Since the surface area factors are much greater the asphalt content would need to be greatly increased to provided the same level of asphalt film thickness, the $9.5 \mathrm{~mm}$ NMAS gradation 1 would require an asphalt content of $17.1 \%$. These levels of asphalt content would not produce 
workable mixes. Examination of Tables E.2 and E.5 indicates the asphalt film thickness would need to be $2 \mu \mathrm{m}$ in order for the volumetric parameters and the asphalt content to reach reasonable levels. These comparison are demonstrated in Figures 4.8 through 4.13.

Figure 4.8 shows the VMA for each of the analysis and the minimum VMA required for the HMA mixture. All the cases meet the criteria, but further evaluation of the percent binder needed shows that the values are unreasonable for the measured the limestone.

Figure 4.9 shows that the measured limestone approach meets the minimum VMA and using Table E.5 the percent binder needed is reasonable for a film thickness of $2 \mu \mathrm{m}$.

Figure 4.10 shows the VFA values for the $19 \mathrm{~mm}$ nominal maximum size gradation \#1 assuming a film thickness of $8 \mu \mathrm{m}$. It also shows the VFA for the same gradation for a film thickness of $2 \mu \mathrm{m}$ using the specific surface area of the measured limestone. The VFA value for a film thickness of $2 \mu \mathrm{m}$ meets the criteria using the specific gravity measured for the limestone material.

Figure 4.11 shows the VMA values for the four $19 \mathrm{~mm}$ nominal maximum aggregate size gradation. Three of the gradation meets the criteria. Gradation \#4 does not meet the criteria by $0.5 \%$, under this circumstance the mix could be acceptable.

Figures 4.12 and 4.13 shows VFA and F/A ratio values, respectively, for the four gradations with a $19 \mathrm{~mm}$ nominal maximum size. They all meet the criteria when it is assumed $2 \mu \mathrm{m}$ for film thickness and the specific surface area for the measured limestone is used for the calculation of the VFA.

It should be noted that the volumetric parameters are sensitive to the compaction energy used to prepare samples. Marshall mix designs use two levels of compaction energy, 50 and 75 blows per side for medium and heavy traffic, respectively. The SuperPave gyratory compactor used to compact SuperPave samples, increases compaction effort by increasing the number of gyrations used for compaction. Mix designs for the high traffic roads use more gyrations than designs for low volume loads. Increasing the compaction effort 
FIGURE 4.8 VMA VALUES FOR 19 mm MIX \#1 $8 \mu \mathrm{m}$ FILM THICKNESS

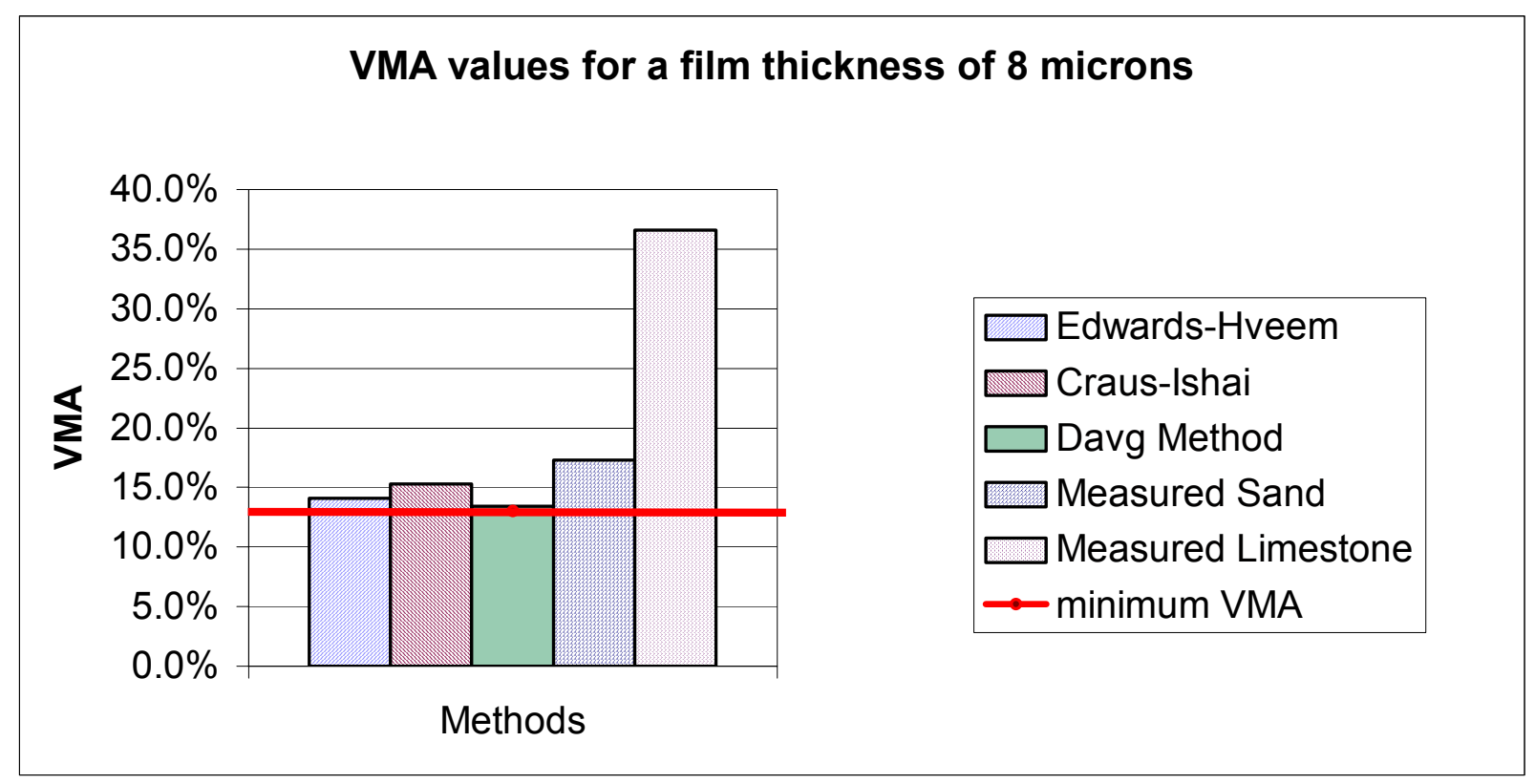

FIGURE 4.9 VMA VALUES FOR 19 mm MIX \#1 $2 \mu \mathrm{m}$ FILM THICKNESS

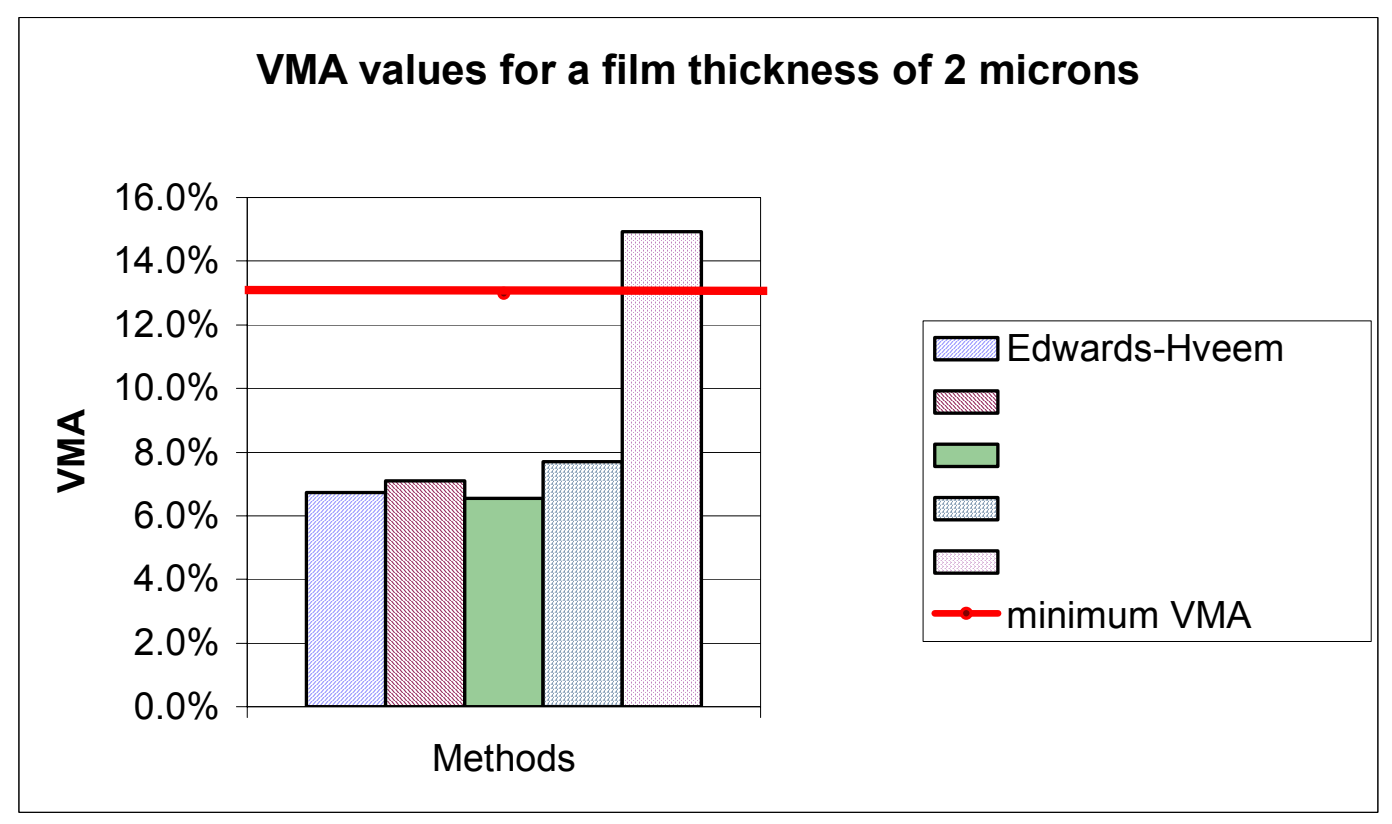


FIGURE 4.10 VFA VALUES FOR 19 mm NMAS \#1

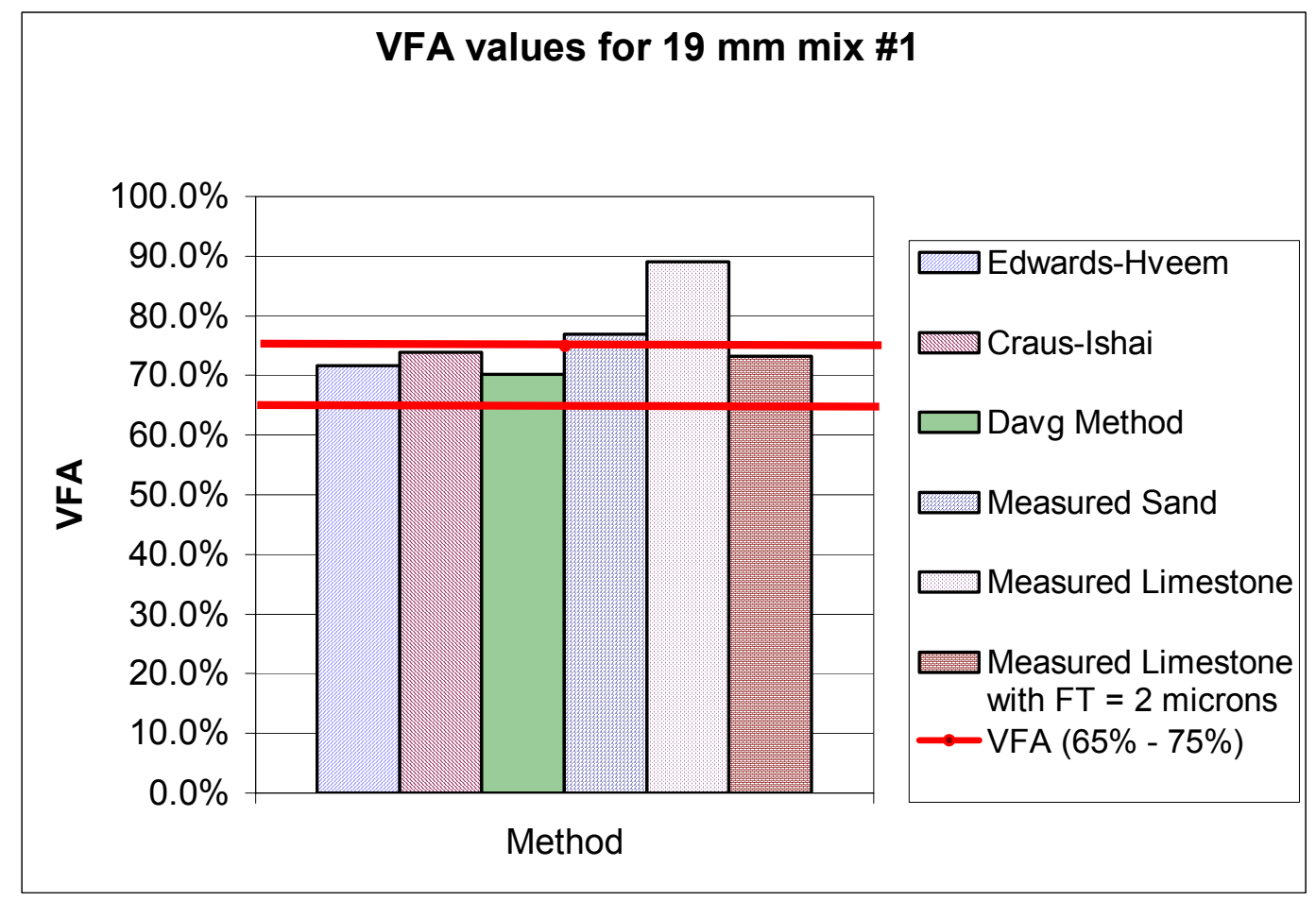

FIGURE 4.11 VMA FOR 19 mm NMAS GRADATIONS $2 \mu \mathrm{m}$ FILM THICKNESS.

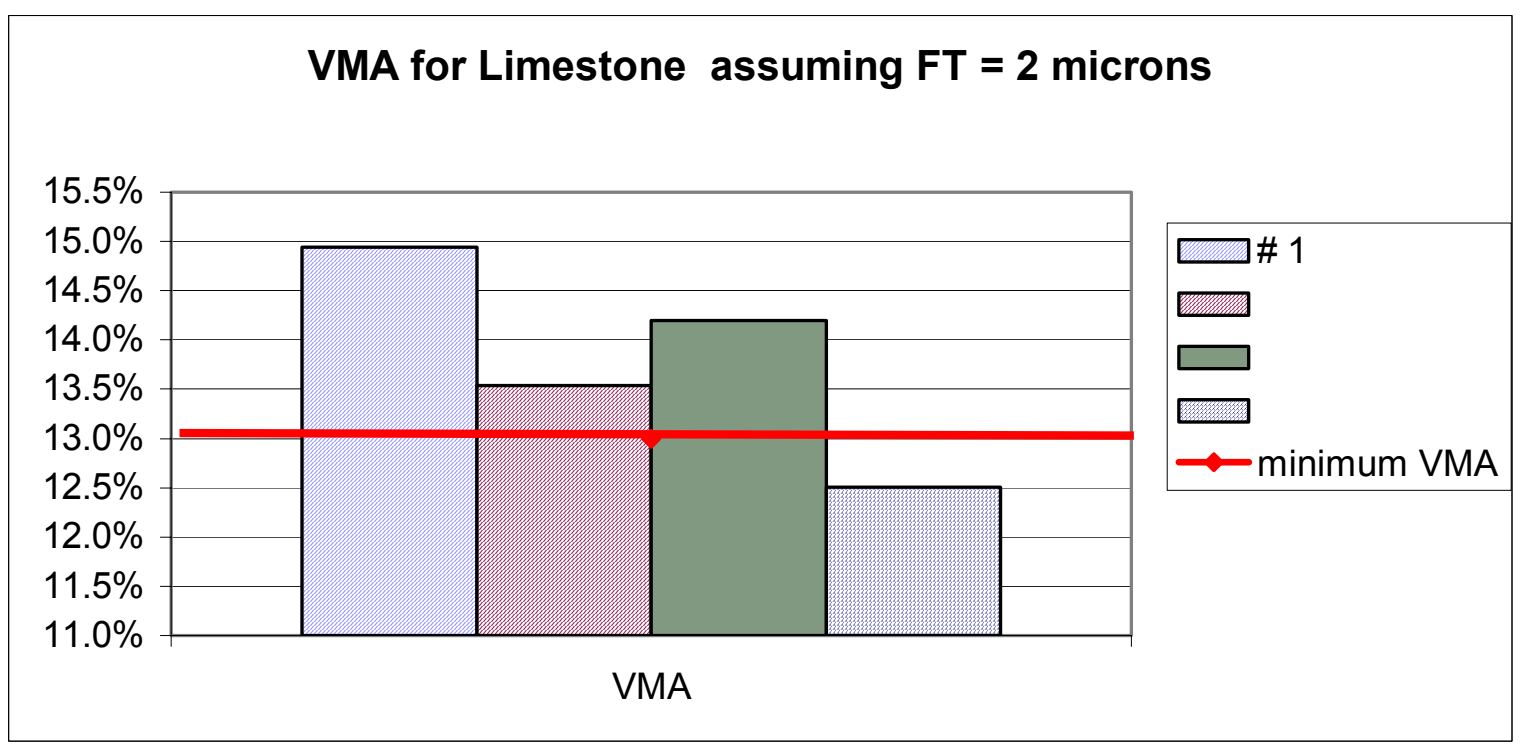


FIGURE 4.12 VFA FOR 19 mm NMAS GRADATIONS $2 \mu \mathrm{m}$. FILM THICKNESS

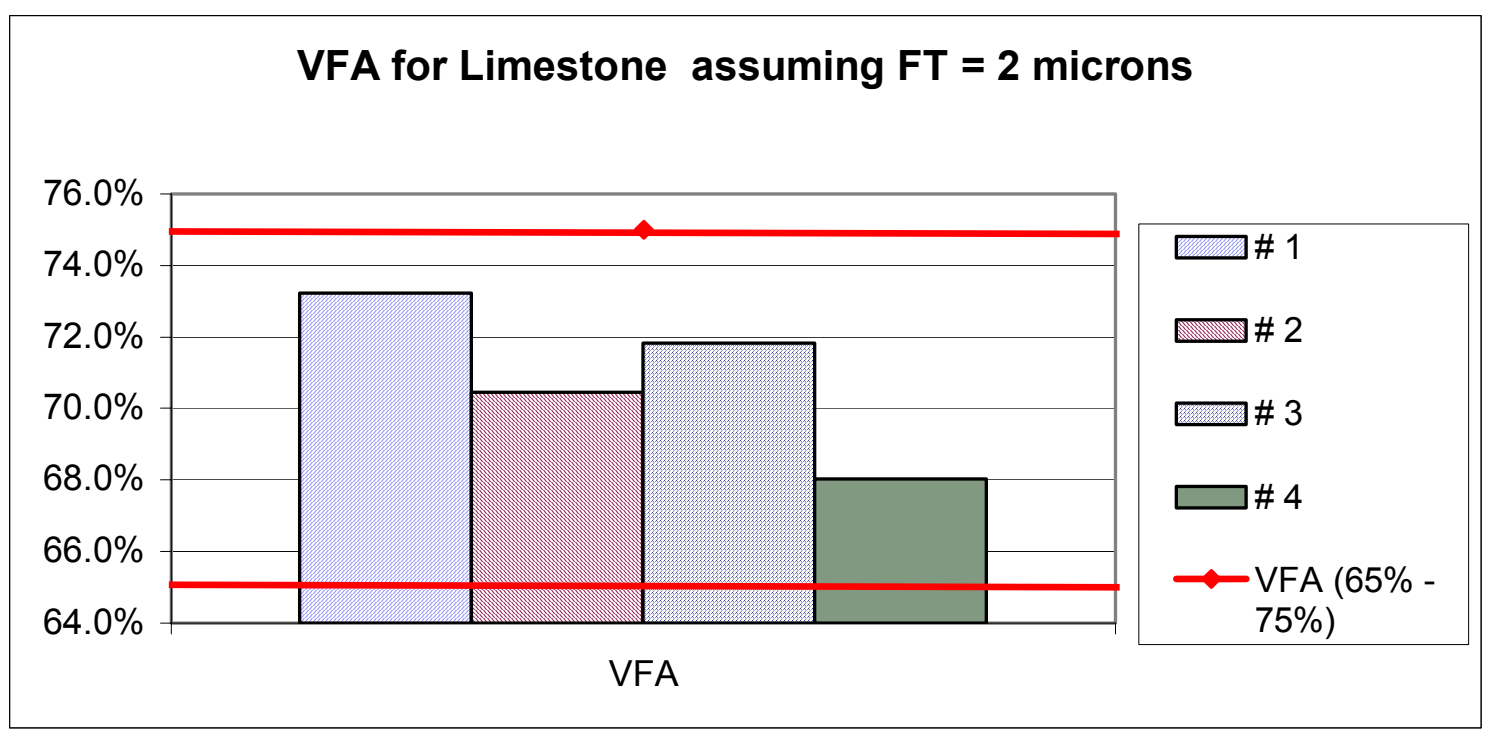

FIGURE 4.13 F/A FOR 19 mm NMAS GRADATIONS $2 \mu \mathrm{m}$. FILM THICKNESS

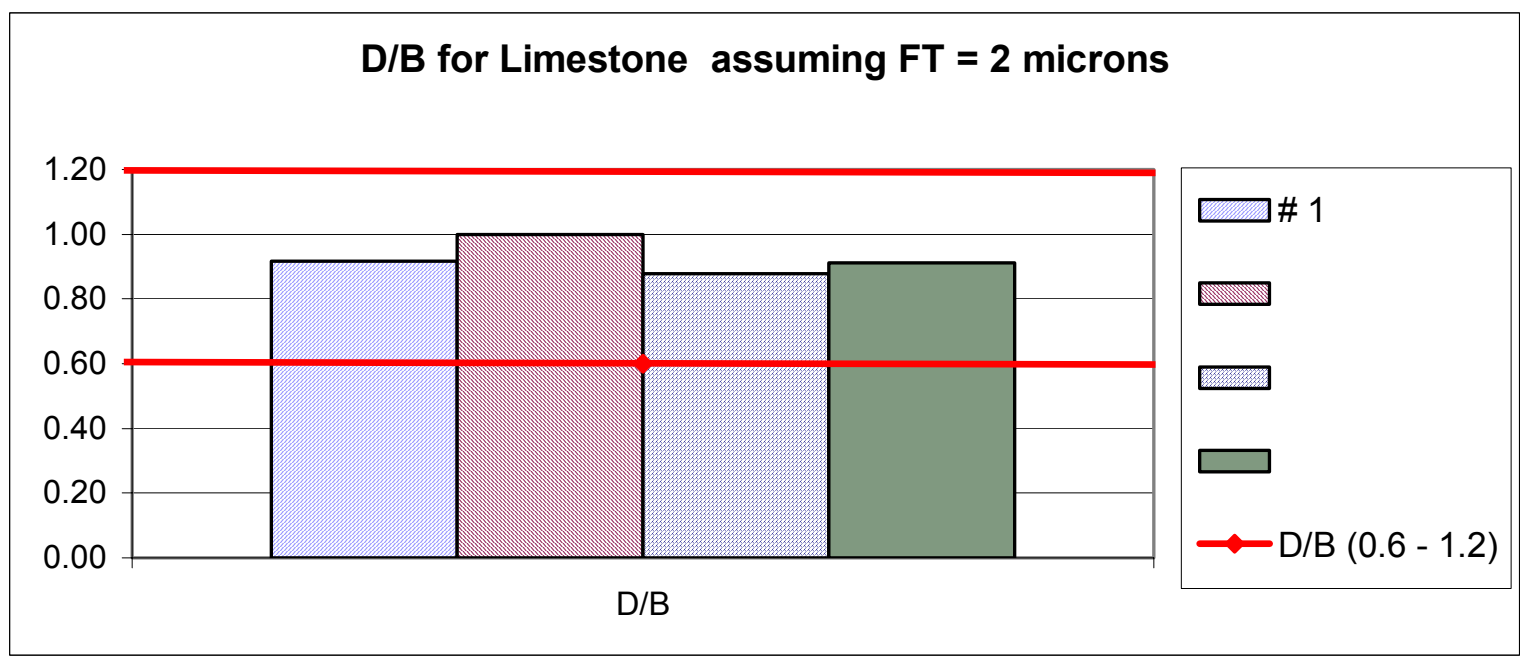


has the effect of reducing the asphalt content needed to produce a certain level of air voids. The effect of compaction effort is not considered in the volumetric analysis based on aggregate surface area.

No data were collected during the research to evaluate how compaction effort would affect the results of the surface area based volumetric analysis. It is hypothesized that due to the angularity and the texture of the limestone, the aggregate provides a structure that is significantly different than the structure produced in a mix with natural sand. This structure would promote the development of voids space between the aggregate, and the hence provide VMA. These factors would not be captured in the volumetric analysis based on the surface area of the aggregates.

\section{EFFECT OF SURFACE AREA ON FILM THICKNESS}

It is possible to determine the asphalt film thickness based on acceptable parameters like VMA $=15.2 \%, \mathrm{VTM}=4 \%$ and a percentage asphalt of $5 \%$. Figure 4.14 presents a $19 \mathrm{~mm}$ mix with surface areas for each of aggergate sources and the Edwards-Hveem values. As expected, the computed film thickness using the measured parameters for the limestone fines is much less than the film thickness computed with the Edwards-Hveem surface area factors. If the film thickness is actually $2 \mu \mathrm{m}$, as indicated on Figure 4.14 , this would indicate the mix should be very rut resistant, but may suffer fatigue and durability problems.

\section{EFFECT OF BAGHOUSE FINES}

During asphalt concrete production, the aggregates are heated and dried in a dryer drum. As the moisture content is reduce, the aggregates release dust that is carried out of the drier and captured in baghouse filters. Since this effectively removes dust from the aggregate, it has become common practice to reintroduce a portion of the baghouse material into the asphalt concrete mix. During mix design, no distinction is made between pan material collected by sieving and the baghouse fines. These materials are treated as if their effect on the mix is interchangeable. Comparison of Tables 4.2 and 4.3 demonstrates that 
FIGURE 4.14 MEASURED SURFACE AREA VS. FILM THICKNESS FOR A $19 \mathrm{~mm}$ MIX.

Specific Surface Area Vs Asphalt Film Thickness
for VMA $=15.2 \%$, VTM $=4 \%, P_{b}=5 \%, 19 \mathrm{~mm}$ mix

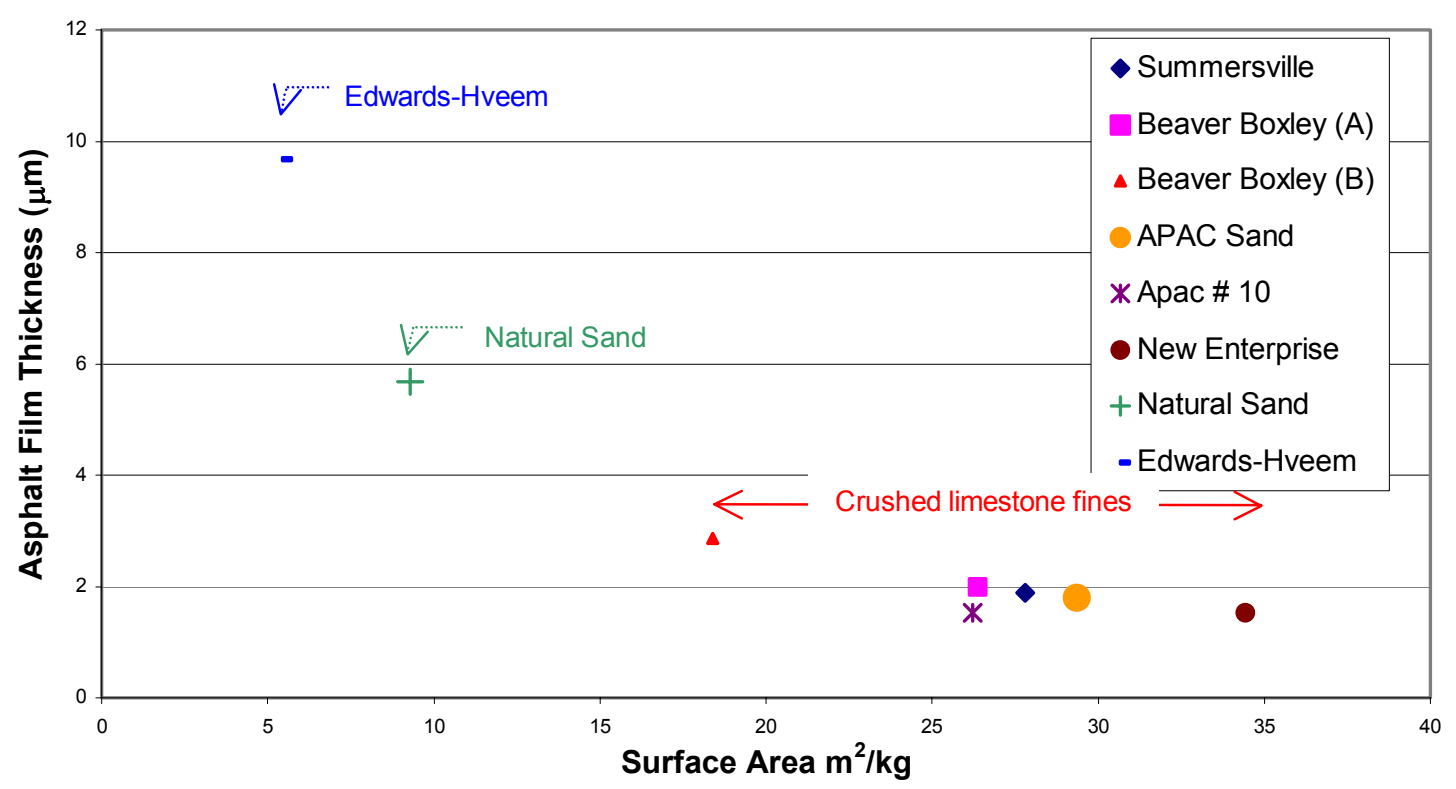

baghouse fines have a much greater surface area than the sieve pan material. The average surface area of the sieved pan material was $452 \mathrm{~m}^{2} / \mathrm{kg}$ and the baghouse fine was $765 \mathrm{~m}^{2} / \mathrm{kg}$.

Due to the greater surface area of the baghouse fines, introducing them into the mix would require increasing the asphalt content in order to maintain a given value of asphalt film thickness. As show in Figure 4.15, there is a significant difference in the required binder content of the mix, when one percent of baghouse material is introduced into the mix. The issue of replacing pan material with baghouse fines has not been addressed in the literature.

\section{SUMMARY OF DATA COLLECTION AND ANALYSIS}

Examination of the traditional methods for computing asphalt film thickness demonstrates several issues which indicate potential errors in the process. The specific surface area factors attributed to Edwards cannot be recreated from stated assumptions. Furthermore, the calculation of the total 
FIGURE 4.15 EFFECT OF BAGHOUSE FINES USING GRADATION \#1 NMAS 19 mm FOR A FILM THICKNESS OF $8 \mu \mathrm{m}$

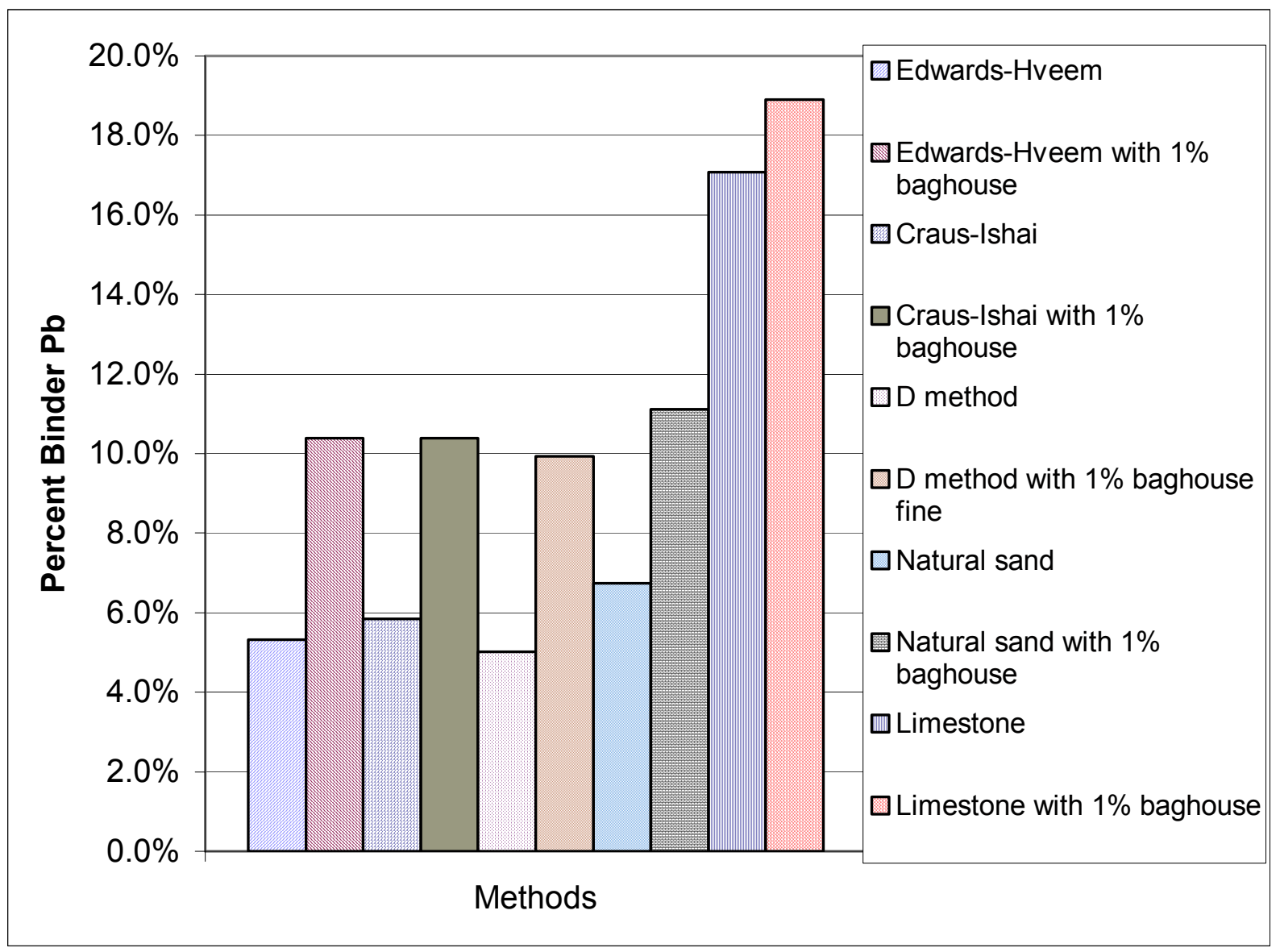

surface area by multiplying a surface area factor, computed based on the opening size of the sieve, by the total percent of material which passes the sieve, is not logical. The Craus-Ishai approach to computing surface area is reproducible. However, the conventional approach is to use these factors with the cumulative percent passing each sieve.

An alternative method for computing surface area factors using the average of the sieve sizes through which the aggregate passes and is retained was developed. These surface area factors were multiplied by amount of material retained on the sieve to determine the surface area. This approach is more defensible than the Edwards-Hveem and Craus-Ishai methods.

Conventional methods of computing surface area of mixture use computed surface area factors. The sole of information in the literature reporting 
measured surface areas indicate measured surface area of fine materials are greater than computed surface areas (Chapuis, 1992). This result was supported by surface area measured during the research. It was found that the measured surface area was approximately 15 times greater than the computed surface area for limestone material finer than $0.075 \mathrm{~mm}$.

Volumetric analysis using surface area factors derived from the literature demonstrates that reasonable results can be produced. However, when the measured values for the surface area are used, the creditability of the results are at issue. The results produced with the measured natural sand specific surface area are within the range of accepted mix design parameters, and the effect of using these factors for mix design could be accommodated by adjusting the volumetric criteria for mix design. However, the same cannot be said for the use of the limestone surface area factors. The measured surface area of fine limestone material is so much greater than the Edwards-Hveem factors that the resulting volumetric analysis cannot reliably represent a realistic mix design.

The inability of the surface area method of volumetric analysis to produce reasonable mix design results highlights the fact that the volumetric properties of a compacted asphalt concrete mix are a function of the compaction effort used to compact the mix. In addition to the surface area, aggregate texture and shape affect compaction characteristics. This suggests the aggregate structure with in the compacted mix must be considered during the volumetric analysis.

Finally, volumetric analysis considering the use of baghouse fines, indicates these materials can have a different effect on the mix properties than the simple replacement of the dust collected by sieving the aggregates. This implies that if baghouse fines are introduced into a mix during production, then this same quantity of baghouse fines should be included during the mix design. 


\section{CHAPTER 5 CONCLUSIONS AND RECOMMENDATIONS}

\section{CONCLUSIONS}

Volumetric criteria for asphalt concrete mix design were derived based on the work of McLeod in the 1950's. These criteria are currently implemented in both the Marshall and the SuperPave methods of mix design. Kandhal researched the criteria and proposed the use of asphalt film thickness as controlling factor in the mix design. However, McLeod and subsequent researchers primarily focused on natural sand fine aggregate and used specific surface area factors. These factors area based on an assumption that the aggregate shape can be characterized as a sphere whose diameter is equal to the length of the sides of the sieve opening.

The conventional method for computing aggregate surface area was carefully evaluated and found to be flawed. An alternative method of using the average dimension of the passing and the retaining sieve dimension, along with the spherical assumption, was developed. Furthermore, it is believed that multiplying the resulting volume by the percent material retained on a sieve reasonably estimates the surface area of the aggregates greater than $0.15 \mathrm{~mm}$.

The surface area of an aggregate blend is strongly dependent on the characteristics and amount of material finer than $0.15 \mathrm{~mm}$. Hence, the surface area of these materials was measured using the Blaine air permeability apparatus. If was found that natural sand has a somewhat greater surface area than computed surface area. However, the measured surface area for limestone fine materials is much greater than both the computed values and the measured sand surface area.

The equations required for performing a volumetric analysis based on surface area were derived from a phase diagram compared to the equations derived by Kandhal et.al (1998-1). There is a dependency in the Kandhal equations with respect to the treatment of absorbed binder. The derived equations were programmed into a spreadsheet and a parametric study was 
performed using different levels of asphalt film thickness and the aggregate gradation.

Based on the evaluation and the analysis performed during this research, several conclusions were developed, which are summarized as:

1. Need to properly account for absorbed binder to correctly compute volumetric properties.

2. Using cumulative percent passing to compute surface area is not accurate.

3. Edwards-Hveem surface area factor cannot be reconstructed from stated assumptions.

4. The Craus-Ishai method for computing surface area factors is reproducible.

5. The specific surface area of an aggregate gradation is dominated by the percent of material passing the $0.15 \mathrm{~mm}$ sieve.

6. The surface area factors computed should be computed using the average of the sieve opening for the passing and the retaining sieve.

7. The surface area for a given aggregate gradation should be computed using the percent material retained on each sieve, rather than using the cumulative percent passing.

8. The measured surface area for the natural sand and the limestone materials fines than $0.15 \mathrm{~mm}$ are significantly greater than the Edwards-Hveem and the Craus-Ishai computed surface area factors. The difference is much greater for the limestone than for the natural sand. The measured values for the mineral filler from natural sand is in reasonable agreement with the coefficient in the Duriez-Arrambide equation. The minimum measured values for the limestone mineral filler agreed with values measured by Chapuis and Legare.

9. Volumetric analysis using the Edwards-Hveem and the Craus-Ishai surface area factors produce reasonable results with respect to 
expectations for mix design. This result is anticipated since mix design criteria were developed from the Edwards-Hveem surface area factors.

10. Volumetric analysis using the measured surface area factors for natural sand and the limestone materials indicates the effective asphalt content must be greater than is required using the Edwards-Hveem surface area factors in order to maintain the asphalt film thickness.

11.Based on the measured values for fine material surface area, if asphalt content remains constant, mixes with limestone fine material will have a much thinner asphalt film thickness than the mixtures made with natural sands. This factor would indicate limestone mixtures are more rut resistant but more fatigue susceptible than natural sand mixtures.

12. The volumetric analysis method based on the surface area factors ignores the effect of the aggregate shape and texture on the compaction ability of the asphalt concrete mixture. Volumetric parameters are dependent on the compaction effort placed on the mixture. Volumetric analysis based on the surface area is not capable of capturing this factor.

\section{RECOMMENDATIONS}

The volumetric analysis method based on aggregate surface area presents an interesting approach for evaluating average asphalt film thickness. However, it would be premature to suggest that asphalt film thickness should be used as a mix design criteria. It is known that asphalt film thickness is directly related to asphalt concrete performance with respect to thermal cracking, fatigue cracking, and rutting. Thus, investigating the relationship between aggregate type and surface area and resulting surface area has great potential in furthering knowledge on the performance of asphalt concrete mixtures. Hence, the recommendations from this research identify areas to refine the surface area 
analysis method and the potential for using this information to improve asphalt concrete performance.

1. There should be further evaluation of limestone fine material surface area. For the materials evaluated during this research, a wide range of surface areas were measured.

2. Further evaluation should be performed on production mix designs. Average film thickness should be computed based on optimum asphalt content, the gradation of the mix and measured surface area of the material finer than $0.15 \mathrm{~mm}$.

3. Research should be performed to relate asphalt film thickness to parameters of pavement distress, including fatigue, thermal cracking, and fatigue. The current findings indicate limestone based materials may be superior to natural sands with respect to rutting, but inferior with respect to fatigue and thermal cracking.

4. Due to the vast difference in the surface area between natural sand and limestone, there may be a need to vary volumetric design criteria as a function of the type of aggregate.

5. The surface area volumetric analysis does not capture the effect of compaction effort on the volumetric properties of the mix. Hence, implementation of this approach would required augmentation of the analytical method with a methodology to capture the compaction characteristics of the mix. 


\section{REFERENCE}

1. Anderson, D.A., and J.P. Tarris, Adding Dust Collectors to Asphalt Paving Mixtures, Transportation Research Board, Washington, D.C., Vol. 252. 1982.

2. Campen, J.F., J.R. Smith, L.G. Erickson, and L.R. Mertz, The Relationship Between Voids, Surface Area, Film Thickness and Stability in Bituminous Paving Mixtures, Proceedings, Association of Asphalt Paving Technologists, Vol. 28, 1959.

3. Chapuis, R.P. and P. Legare, A Simple Method for Determination the Surface Area of Fine Aggregates and Fillers in Bituminous Mixtures, ASTM STP 1147, Philadelphia, PA, 1992

4. Craus, J., and I. Ishai, A Method for Determination of the Surface Area of Fine Aggregates in Bituminous Mixtures, Journal of Testing and Evaluation, Vol. 5., 1977.

5. Duriez, M., and J. Arrambide, Nouveau Traite de Materiaux de Construction, Paris, 1962.

6. Federal Highway Administration. Status of the Nation's Highways, Bridges, and Transit: 2002 Conditions and Performance Report. http://www.fhwa.dot.gov/policy/2002cpr/ch1.htm. 02/27/2002

7. Harman, T., J. D'Angelo, and J. Bukowski, Federal Highway Administration. SuperPave Asphalt Mixture Design. Workbook Version 5.1. Washington D.C. January 1999.

8. Kandhal, P.S., C.Y. Lynn, and F. Parker, Jr., Characterization Tests for Mineral Fillers Related to Performance of Asphalt Paving Mixtures. NCAT Report No.98-2. Auburn University, AL., January 1998.

9. Kandhal, P.S., K.Y. Foo, and R.B. Mallick. A Critical Review of VMA Requirements in SuperPave. NCAT Report No.98-1. Auburn University, AL., January 1998. 
10. Kanneganti, V., Comparison of $19 \mathrm{~mm}$ SuperPave and Marshall Base II Mixes in West Virginia, West Virginia University. Morgantown, WV. 2002

11. McLeod, N.W., Relationship Between Density, Bitumen Content, and Voids Properties of Compacted Bituminous Paving Mixtures. Proceedings, Highway Research Board, Volume 35, Washington, DC, 1956

12. McLeod, N.W., Voids Requirements for Dense-Graded Bituminous Paving Mixtures. Special Technical Publication 252, ASTM, Philadelphia, PA., 1959.

13. Roberts F.L., P.S. Kandhal, E.R. Brown, D. Lee, and T. W. Kennedy, Hot Mix Asphalt Materials, Mixture Design, and Construction. Second Edition, National Asphalt Pavement Association, Lanham, MD., 1996.

14. The Asphalt Institute, Mix Design Methods for Asphalt Concrete and other Hot Mix Types, MS-2, Sixth Edition, 1993.

15. Tunnicliff, D.G., Biding Effects of Mineral Filler. Proceedings, Association of Asphalt Paving Technologists, Vol. 36, 1967. 


\section{SPECIFICATIONS}

1. West Virginia Division of Highways, Standard Specifications, 2000.

2. Standard Specification for SuperPave Volumetric Mix Design. AASHTO Designation MP 2-99, 1999.

3. Guide to Designing Hot-Mix Asphalt using the Marshall Design Method. WVDOT MP 402.02.22.2000.

4. Guide to Designing Hot-Mix Asphalt using the SuperPave Volumetric Design System. WVDOT MP 402.02.28.2000.

5. Bulk Specific Gravity of Bituminous Paving Mixtures. AASHTO T166. 1993.

6. Maximum Specific Gravity of Bituminous Paving Mixtures. AASHTO T209. 1994.

7. Determination of Specific Gravity and Absorption of Course Aggregate. AASHTO T85. 1991.

8. Determination of Specific Gravity and Absorption of Fine Aggregate. AASHTO T84. 1994.

9. Determination of Specific Gravity of Asphalt Cement. AASHTO 228. 1994.

10. Standard Test Method for Finesses of Hydraulic Cement by Air Permeability Apparatus. ASTM C204. 1996

11. Standard Test Method for Density of Hydraulic Cement. ASTM C188. 1995 


\section{APPENDIX A SPECIFIC GRAVITY OF SAMPLES}

TABLE A.1 SPECIFIC GRAVITIES OF THE FINE MATERIAL EVALUATED

\begin{tabular}{|l|c|c|c|c|c|c|c|}
\hline \multicolumn{1}{|c|}{ Material } & $\mathrm{A}$ & $\mathrm{B}$ & $\mathrm{C}$ & $\mathrm{D}$ & $\mathrm{G}_{\mathrm{sb}}$ & $\mathrm{G}_{\mathrm{Sa}}$ & $\mathrm{Ab} \%$ \\
\hline APAC sample \#1 & & & & & 2.684 & 2.780 & 1.29 \\
\hline APAC sample \#2 & & & & & 2.603 & 2.692 & 1.28 \\
\hline $\begin{array}{l}\text { Meadows Stone \& Paving. } \\
\text { Sample (A) }\end{array}$ & 499.6 & 658.9 & 976.3 & 504.7 & 2.667 & 2.742 & 1.02 \\
\hline $\begin{array}{l}\text { Meadows Stone \& Paving } \\
\text { Sample (B) }\end{array}$ & 494.1 & 658.9 & 973.6 & 503.3 & 2.620 & 2.754 & 1.86 \\
\hline $\begin{array}{l}\text { New Enterprise Stone \& } \\
\text { lime }\end{array}$ & & & & & 2.523 & & \\
\hline \multirow{2}{*}{\begin{tabular}{l} 
Southern W.V. Paving, Inc \\
\cline { 2 - 8 }
\end{tabular}} & 491.2 & 658.8 & 969.8 & 501.7 & 2.576 & 2.726 & 2.14 \\
\hline \multirow{2}{*}{ Natural Sand } & 490.2 & 658.8 & 965.0 & 500.5 & 2.523 & 2.664 & 2.10 \\
\cline { 2 - 8 } & 489.7 & 679.8 & 985.9 & 500.3 & 2.522 & 2.667 & 2.16 \\
\hline
\end{tabular}

Where:

$A=$ mass of oven dry sample in air, grams.

$B=$ Mass of pycnometer filled to calibration mark with distilled water, grams.

C = Mass of pycnometer, sample and water to calibration, grams.

$\mathrm{D}=$ Mass saturated-surface-dry sample in air, grams.

$\mathrm{G}_{\mathrm{sb}}=$ Bulk specific gravity.

$\mathrm{G}_{\mathrm{sa}}=$ Apparent specific gravity.

$\% A b .=$ Percent absorption. 
TABLE A.2 SPECIFIC GRAVITIES OF THE BAGHOUSE MATERIAL EVALUATED

\begin{tabular}{|c|c|c|c|c|}
\hline Material & A & B & $\mathrm{G}_{\mathrm{sb}}$ & Average $\mathrm{G}_{\mathrm{sb}}$ \\
\hline \multirow{3}{*}{ APAC sample 1} & 56.097 & 20.7 & 2.710 & \multirow{3}{*}{2.707} \\
\hline & 55.461 & 20.5 & 2.705 & \\
\hline & 56.014 & 20.7 & 2.706 & \\
\hline \multirow{3}{*}{ J.F. Allen Company } & 53.893 & 20.8 & 2.591 & \multirow{3}{*}{2.588} \\
\hline & 53.713 & 20.9 & 2.570 & \\
\hline & 54.684 & 21.0 & 2.604 & \\
\hline \multirow{3}{*}{ Meadows Stone \& Paving, Sample (A) } & 52.925 & 19.8 & 2.673 & \multirow{3}{*}{2.672} \\
\hline & 52.560 & 19.7 & 2.668 & \\
\hline & 52.698 & 19.7 & 2.675 & \\
\hline \multirow{3}{*}{ Meadows Stone \& Paving, Sample (B) } & 56.035 & 20.8 & 2.694 & \multirow{3}{*}{2.687} \\
\hline & 53.480 & 19.8 & 2.701 & \\
\hline & 55.186 & 20.7 & 2.666 & \\
\hline \multirow{3}{*}{ New Enterprise Stone \& lime } & 56.826 & 21.0 & 2.706 & \multirow{3}{*}{2.706} \\
\hline & 55.432 & 20.5 & 2.704 & \\
\hline & 56.326 & 20.8 & 2.708 & \\
\hline \multirow{3}{*}{ Tri-State Asphalt Company } & 55.610 & 20.4 & 2.726 & \multirow{3}{*}{2.730} \\
\hline & 56.259 & 20.6 & 2.731 & \\
\hline & 56.027 & 20.5 & 2.733 & \\
\hline \multirow{3}{*}{ West Virginia Paving, Inc } & 56.448 & 21.0 & 2.688 & \multirow{3}{*}{2.686} \\
\hline & 54.835 & 20.4 & 2.688 & \\
\hline & 55.249 & 20.6 & 2.682 & \\
\hline \multirow{3}{*}{ Gasaway } & 54.782 & 20.2 & 2.712 & \multirow{3}{*}{2.712} \\
\hline & 54.200 & 20.0 & 2.710 & \\
\hline & 51.314 & 18.9 & 2.715 & \\
\hline \multirow{3}{*}{ Southern W.V. Paving, Inc (Summersville) } & 54.520 & 20.0 & 2.726 & \multirow{3}{*}{2.723} \\
\hline & 53.351 & 19.6 & 2.722 & \\
\hline & 51.219 & 18.9 & 2.710 & \\
\hline
\end{tabular}


Where:

$A=$ Mass of oven-dry sample in air, grams

$\mathrm{B}=$ Volume displaced, $\mathrm{cm}^{3}$.

$\mathrm{G}_{\mathrm{sb}}=$ Bulk specific gravity. 


\section{APPENDIX B SURFACE AREA FOR THE MATERIAL PASS 0.15MM AND RETAINED ON 0.075MM}

\section{TABLE B.1 APAC SAMPLE \# 2 SURFACE AREA FOR THE MATERIAL PASS $0.15 \mathrm{~mm}$ AND RETAINED ON $0.075 \mathrm{~mm}$.}

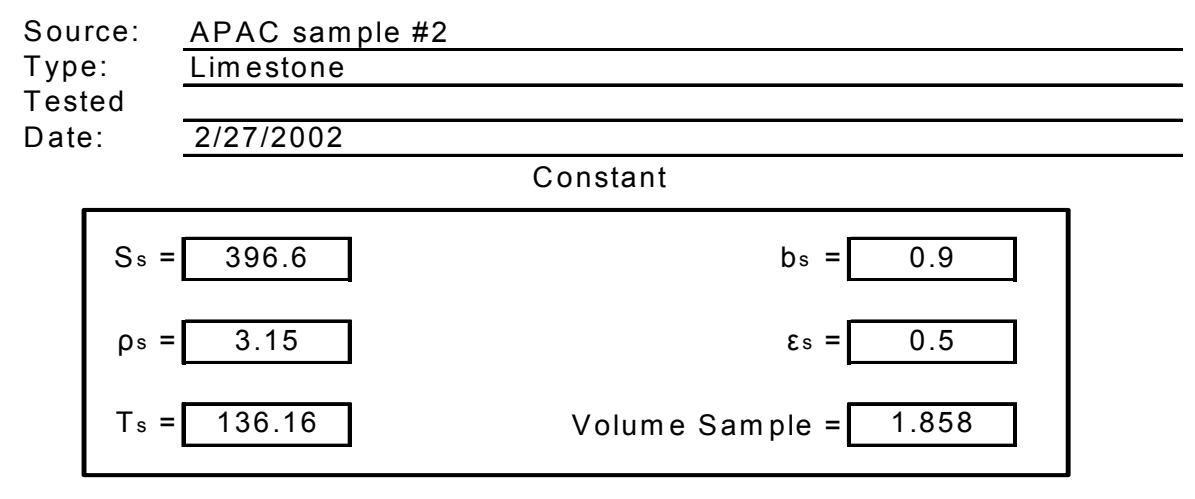

Temperature $=24$

S. G. (oven Dry Sample) $=2.603$

\begin{tabular}{|c|c|c|c|c|c|c|c|}
\hline Porosity & Weight of Sample & $\# 1$ & $\# 2$ & $\# 3$ & $\# 4$ & $\# 5$ & $\# 6$ \\
\hline 0.513 & 2.358 & 3.53 & 3.55 & 3.56 & 3.56 & 3.55 & 3.53 \\
\hline 0.500 & 2.418 & 3.87 & 3.90 & 3.87 & 3.90 & 3.83 & 3.87 \\
\hline 0.488 & 2.479 & 4.25 & 4.21 & 4.26 & 4.31 & 4.25 & 4.18 \\
\hline 0.475 & 2.539 & 4.56 & 4.63 & 4.68 & 4.68 & 4.70 & 4.63 \\
\hline
\end{tabular}

\begin{tabular}{|c|c|c|c|c|}
\hline Porosity & W eight of Sample & $\mathrm{T}$ & $\sqrt{\varepsilon^{3} T}$ & $\mathrm{~S}$ \\
\hline 0.513 & 2.358 & 3.55 & 0.691 & 18.452 \\
\hline 0.500 & 2.418 & 3.87 & 0.696 & 18.449 \\
\hline 0.488 & 2.479 & 4.24 & 0.701 & 18.459 \\
\hline 0.475 & 2.539 & 4.65 & 0.706 & 18.448
\end{tabular}$\quad \mathrm{~b}=\begin{gathered}2.255 \\
\text { Correlation Coefficient }=0.9996 \quad>0.997\end{gathered}$

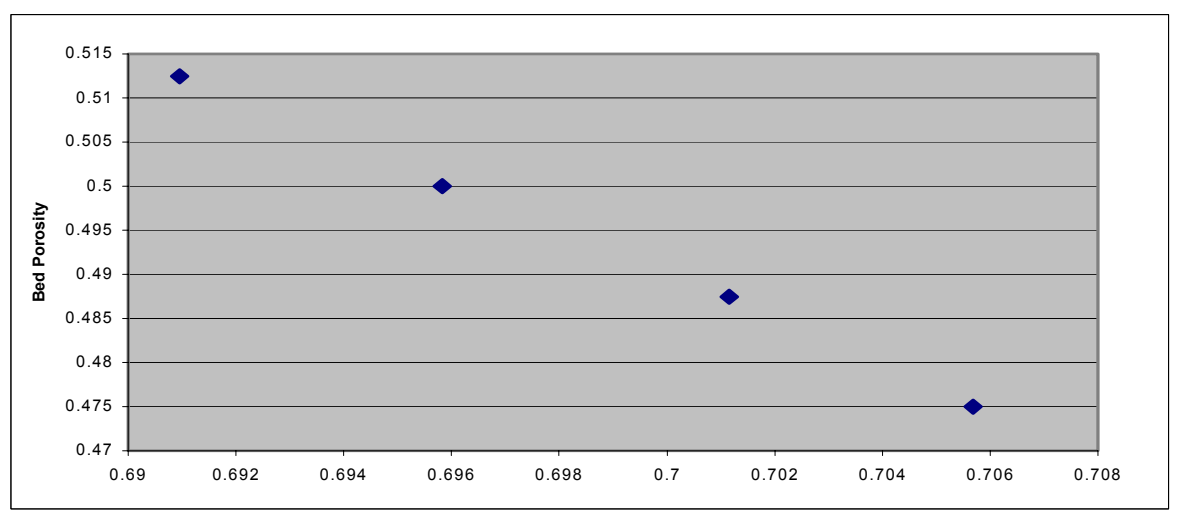


TABLE B.2 APAC SAMPLE \#1 SURFACE AREA FOR THE MATERIAL PASS $0.15 \mathrm{~mm}$ AND RETAINED ON $0.075 \mathrm{~mm}$.

Source: $\quad$ APAC sample \#1

$\begin{array}{ll}\text { Type: } & \text { Limestone } \\ \text { Tested } & \\ \text { Date: } & 3 / 1 / 2002 \quad \text { Constant }\end{array}$

$\begin{array}{rlr}S_{s}=396.6 & b_{s}=0.9 \\ \rho_{s}=3.15 & \varepsilon_{s}=0.5 \\ T_{s}=136.16 & \text { Volume Sample }=1.858\end{array}$

Temperature $=24 \quad$ S. G. (oven Dry Sample) $=2.684$

\begin{tabular}{|c|c|c|c|c|c|c|c|}
\hline Porosity & Weight of Sample & $\# 1$ & $\# 2$ & $\# 3$ & $\# 4$ & $\# 5$ & $\# 6$ \\
\hline 0.5 & 2.493 & 3.03 & 3.04 & 3.07 & 3.04 & 3.06 & 3.03 \\
\hline 0.488 & 2.553 & 3.39 & 3.38 & 3.35 & 3.35 & 3.28 & 3.35 \\
\hline 0.475 & 2.618 & 3.74 & 3.77 & 3.74 & 3.76 & 3.73 & 3.73 \\
\hline 0.463 & 2.678 & 4.15 & 4.13 & 4.15 & 4.16 & 4.13 & 4.18 \\
\hline
\end{tabular}

\begin{tabular}{|c|c|c|c|c|c|}
\hline Porosity & Weight of Sample & $T$ & $\sqrt{\varepsilon^{3} T}$ & $S$ & \\
\hline 0.500 & 2.493 & 3.05 & 0.617 & 30.713 & \\
\hline 0.488 & 2.553 & 3.35 & 0.624 & 30.656 & \\
\hline 0.475 & 2.618 & 3.75 & 0.634 & 30.692 & \\
\hline 0.463 & 2.678 & 4.15 & 0.642 & 30.697 & $b=1.407$ \\
\hline
\end{tabular}

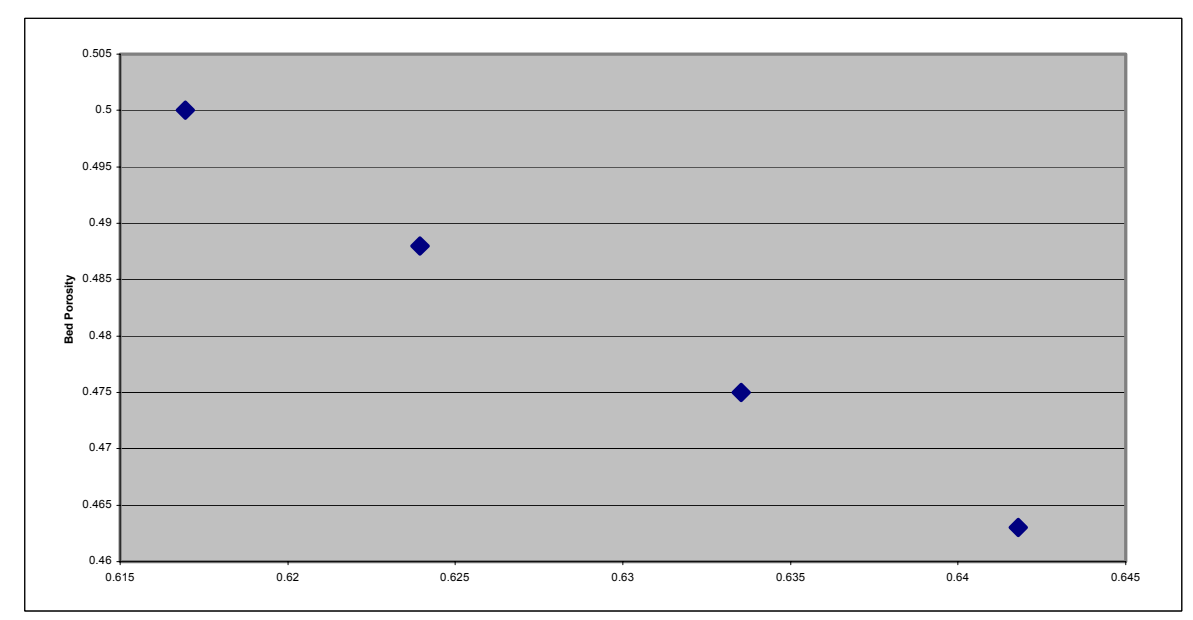


TABLE B.3 SUMMERSVILLE LIMESTONE SURFACE AREA FOR THE MATERIAL PASS $0.15 \mathrm{~mm}$ AND RETAINED ON $0.075 \mathrm{~mm}$.

Source: Summerville

\begin{tabular}{ll} 
Type: & Limestone \\
Tested & \\
\cline { 2 - 2 } Date: & $3 / 2 / 2002$ \\
\cline { 2 - 2 } &
\end{tabular}

\begin{tabular}{rr|}
\hline$S_{s}=396.6$ & $b_{s}=0.9$ \\
$\rho_{s}=1.15$ & $\varepsilon_{s}=0.5$ \\
$T_{s}=136.16$ & Volume Sample $=1.858$
\end{tabular}

Temperature $=24 \quad$ S. G. (oven Dry Sample) $=2.575$

\begin{tabular}{|c|c|c|c|c|c|c|c|}
\hline Porosity & Weight of Sample & $\# 1$ & $\# 2$ & $\# 3$ & $\# 4$ & $\# 5$ & $\# 6$ \\
\hline 0.470 & 2.536 & 3.78 & 3.75 & 3.81 & 3.74 & 3.77 & 3.73 \\
\hline 0.455 & 2.607 & 4.21 & 4.28 & 4.31 & 4.26 & 4.21 & 4.24 \\
\hline 0.440 & 2.679 & 4.96 & 4.81 & 4.75 & 4.83 & 4.87 & 4.76 \\
\hline 0.430 & 2.727 & 5.28 & 5.27 & 5.24 & 5.22 & 5.24 & 5.23 \\
\hline
\end{tabular}

\begin{tabular}{|c|c|c|c|c|}
\hline Porosity & Weight of Sample & $\mathrm{T}$ & $\sqrt{\varepsilon^{3} T}$ & $\mathrm{~S}$ \\
\hline 0.470 & 2.536 & 3.76 & 0.625 & 24.842 \\
\hline 0.455 & 2.607 & 4.25 & 0.633 & 24.836 \\
\hline 0.440 & 2.679 & 4.83 & 0.641 & 24.862 \\
\hline 0.430 & 2.727 & 5.25 & 0.646 & 24.829 \\
Correlation Coefficient $=0.9992 \quad \mathrm{~b}=0.997$
\end{tabular}

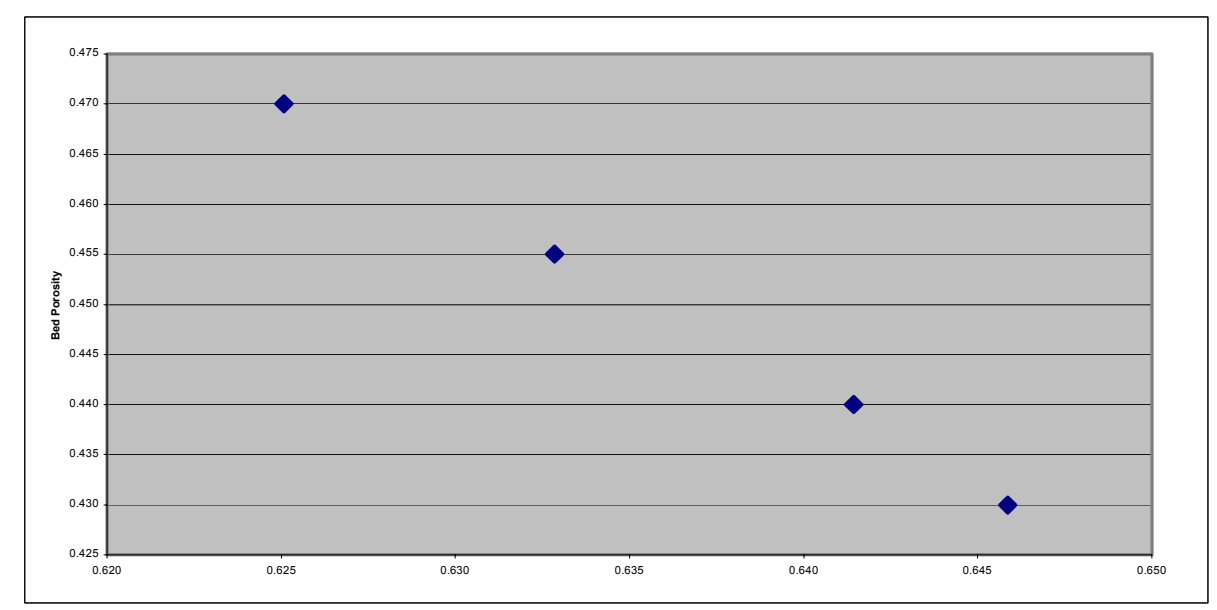


TABLE B.4 BEAVER BOXLEY (A) SURFACE AREA FOR THE MATERIAL PASS $0.15 \mathrm{~mm}$ AND RETAINED ON $0.075 \mathrm{~mm}$.

\begin{tabular}{ll} 
Source: & Beaver Boxley $(\mathrm{A})$ \\
Type: & Limestone \\
Tested & \\
Date: & $3 / 4 / 2002$ \\
\cline { 2 - 2 } &
\end{tabular}

\begin{tabular}{|c|c|c|c|}
\hline$S_{s}=$ & 396.6 & $b_{s}=$ & 0.9 \\
\hline$\rho_{\mathrm{s}}=$ & 3.15 & $\varepsilon_{\mathrm{s}}=$ & 0.5 \\
\hline$T_{s}=$ & 136.16 & Volume Sample $=$ & 1.858 \\
\hline
\end{tabular}

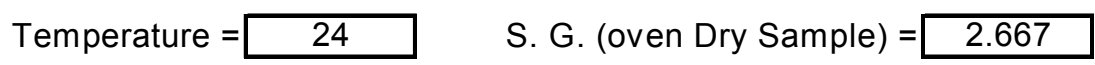

Time

\begin{tabular}{|c|c|c|c|c|c|c|c|}
\hline Porosity & Weight of Sample & $\# 1$ & $\# 2$ & $\# 3$ & $\# 4$ & $\# 5$ & $\# 6$ \\
\hline 0.500 & 2.478 & 2.31 & 2.28 & 2.37 & 2.06 & 2.22 & 2.27 \\
\hline 0.485 & 2.552 & 2.84 & 2.87 & 2.78 & 2.21 & 2.21 & 2.34 \\
\hline 0.470 & 2.626 & 3.03 & 3.00 & 3.15 & 2.68 & 2.65 & 2.71 \\
\hline 0.455 & 2.701 & 3.09 & 3.28 & 3.37 & 3.12 & 3.32 & 3.20 \\
\hline
\end{tabular}

\begin{tabular}{|c|c|c|c|c|c|}
\hline Porosity & Weight of Sample & $\bar{T}$ & $\sqrt{\varepsilon^{3} T}$ & $S$ & \\
\hline 0.500 & 2.478 & 2.25 & 0.531 & 21.465 & \\
\hline 0.485 & 2.552 & 2.54 & 0.538 & 21.500 & \\
\hline 0.470 & 2.626 & 2.87 & 0.546 & 21.511 & \\
\hline 0.455 & 2.701 & 3.23 & 0.552 & 21.457 & 1.623 \\
\hline
\end{tabular}

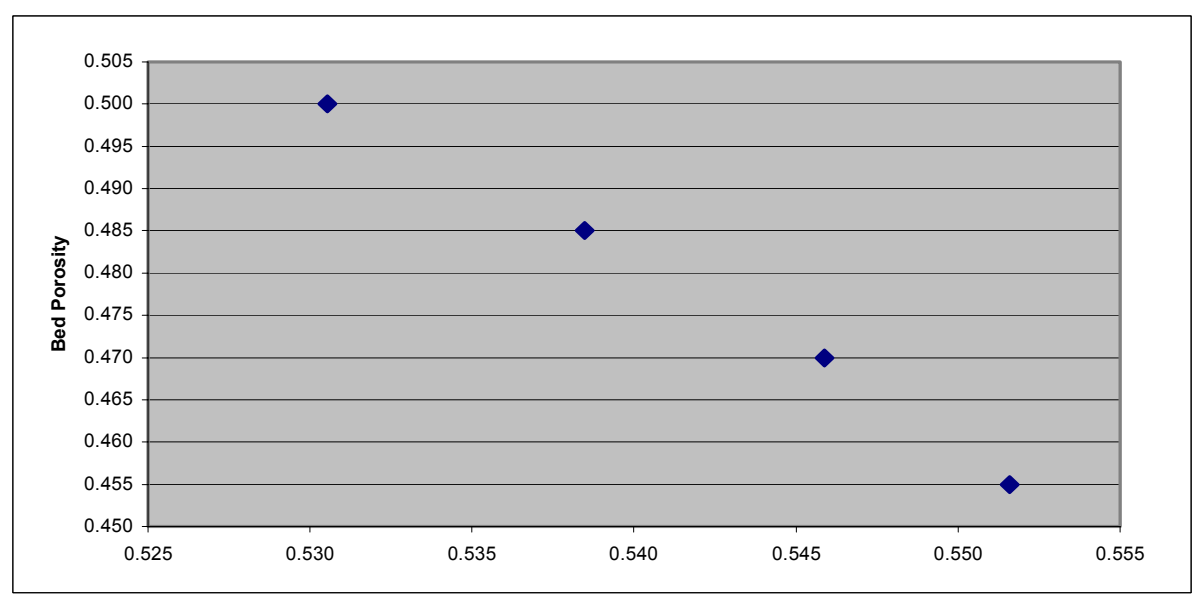


TABLE B.5 BEAVER BOXLEY (B) SURFACE AREA FOR THE MATERIAL PASS $0.15 \mathrm{~mm}$ AND RETAINED ON $0.075 \mathrm{~mm}$.

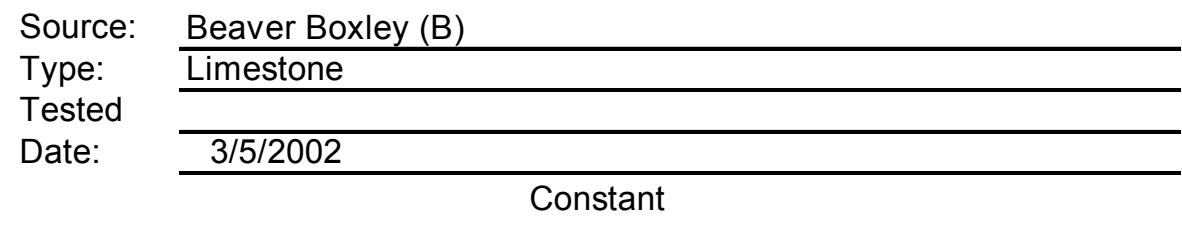

\begin{tabular}{|c|c|c|c|}
\hline $\mathrm{S}_{\mathrm{s}}=$ & 396.6 & $\mathrm{bs}=$ & 0.9 \\
\hline$\rho_{\mathrm{s}}=$ & 3.15 & $\varepsilon_{\mathrm{s}}=$ & 0.5 \\
\hline $\mathrm{T}_{\mathrm{s}}=$ & 136.16 & Volume Sample $=$ & 1.858 \\
\hline
\end{tabular}

Temperature $=24 \quad$ S. G. (oven Dry Sample) $=2.620$

\begin{tabular}{|c|c|c|c|c|c|c|c|}
\hline Porosity & Weight of Sample & $\# 1$ & $\# 2$ & $\# 3$ & $\# 4$ & $\# 5$ & $\# 6$ \\
\hline 0.513 & 2.373 & 2.53 & 3.65 & 3.56 & 3.56 & 3.65 & 3.60 \\
\hline 0.500 & 2.434 & 2.87 & 3.90 & 3.93 & 3.90 & 3.93 & 3.87 \\
\hline 0.488 & 2.495 & 3.25 & 4.21 & 4.26 & 4.21 & 4.25 & 4.24 \\
\hline 0.475 & 2.556 & 3.56 & 4.53 & 4.68 & 4.68 & 4.70 & 4.53 \\
\hline
\end{tabular}

\begin{tabular}{|c|c|c|c|c|c|}
\hline Porosity & Weight of Sample & $T$ & $\sqrt{\varepsilon^{3} T}$ & $S$ & \\
\hline 0.513 & 2.373 & 3.43 & 0.679 & 13.899 & \\
\hline 0.500 & 2.434 & 3.73 & 0.683 & 13.907 & \\
\hline 0.488 & 2.495 & 4.07 & 0.687 & 13.903 & \\
\hline 0.475 & 2.556 & 4.45 & 0.690 & 13.900 & $b=2.771$ \\
\hline
\end{tabular}

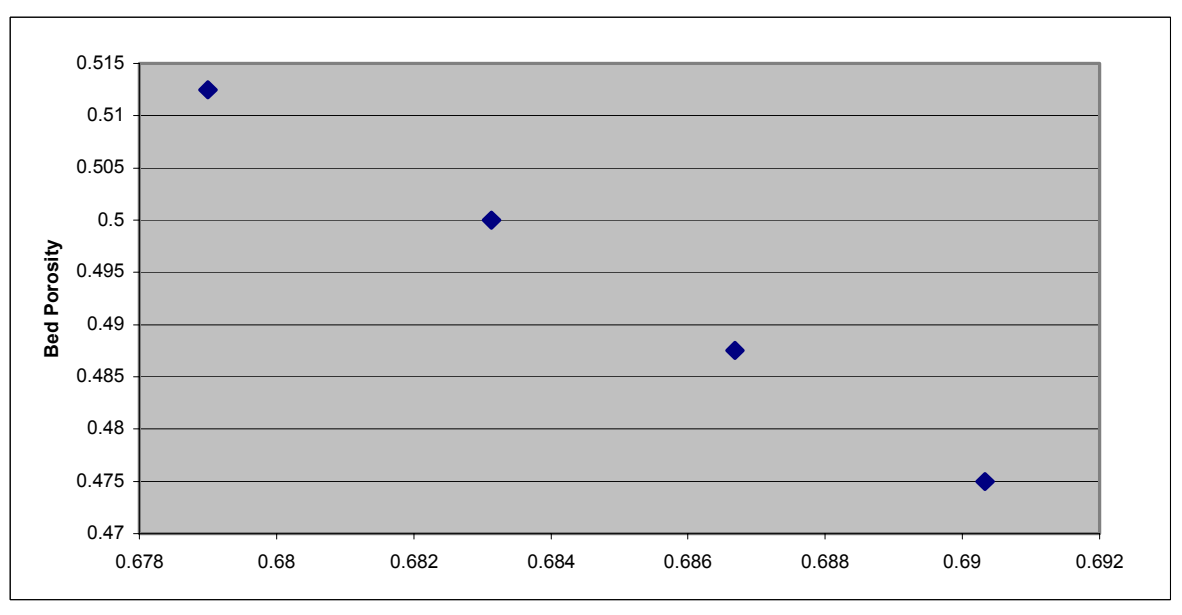


TABLE B.6 NEW ENTERPRISE SURFACE AREA FOR THE MATERIAL PASS $0.15 \mathrm{~mm}$ AND RETAINED ON $0.075 \mathrm{~mm}$.

Source: New Enterprise

\begin{tabular}{ll} 
Type: & Limestone \\
Tested & \\
\cline { 2 - 2 } Date: & $3 / 7 / 2002$ \\
\cline { 2 - 2 } &
\end{tabular}

\begin{tabular}{rlr|}
\hline$S_{s}=396.6$ & $b_{s}=10.9$ \\
$\rho_{s}=$ & $\varepsilon_{s}=0.5$ \\
$T_{s}=15.16$ & Volume Sample $=1.858$
\end{tabular}

Temperature $=24 \quad$ S. G. (oven Dry Sample) $=2.523$

Time

\begin{tabular}{|c|c|c|c|c|c|c|c|}
\hline Porosity & Weight of Sample & $\# 1$ & $\# 2$ & $\# 3$ & $\# 4$ & $\# 5$ & $\# 6$ \\
\hline 0.500 & 2.344 & 3.18 & 3.00 & 3.12 & 3.06 & 3.15 & 3.15 \\
\hline 0.488 & 2.400 & 3.35 & 3.34 & 3.34 & 3.35 & 3.41 & 3.43 \\
\hline 0.475 & 2.461 & 3.71 & 3.75 & 3.64 & 3.71 & 3.65 & 3.71 \\
\hline 0.463 & 2.517 & 3.96 & 4.09 & 4.03 & 4.00 & 4.03 & 4.03 \\
\hline
\end{tabular}

\begin{tabular}{|c|c|c|c|c|}
\hline Porosity & Weight of Sample & $\mathrm{T}$ & $\sqrt{\varepsilon^{3} T}$ & $\mathrm{~S}$ \\
\hline 0.500 & 2.344 & 3.11 & 0.623 & 11.182 \\
\hline 0.488 & 2.400 & 3.37 & 0.626 & 11.173 \\
\hline 0.475 & 2.461 & 3.70 & 0.629 & 11.181 \\
\hline 0.463 & 2.517 & 4.02 & 0.632 & 11.178
\end{tabular}$\quad \mathrm{~b}=\begin{gathered}3.177 \\
\quad \text { Correlation Coefficient }=0.9983 \quad>0.997\end{gathered}$

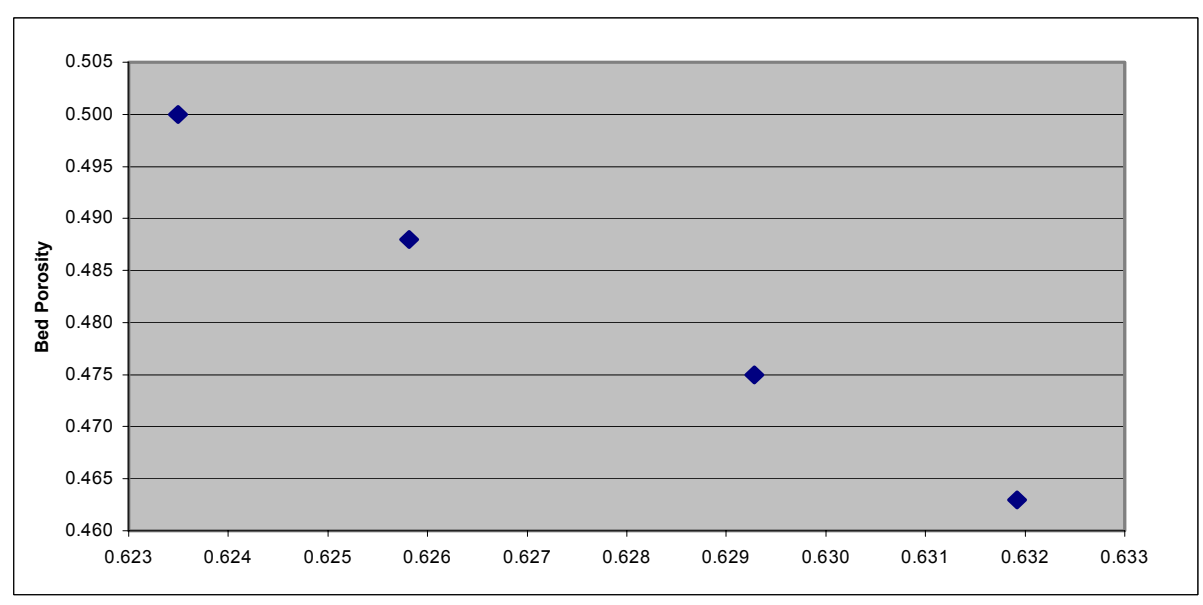




\section{TABLE B.7 NATURAL SAND SURFACE AREA FOR THE MATERIAL PASS $0.15 \mathrm{~mm}$ AND RETAINED ON $0.075 \mathrm{~mm}$.}

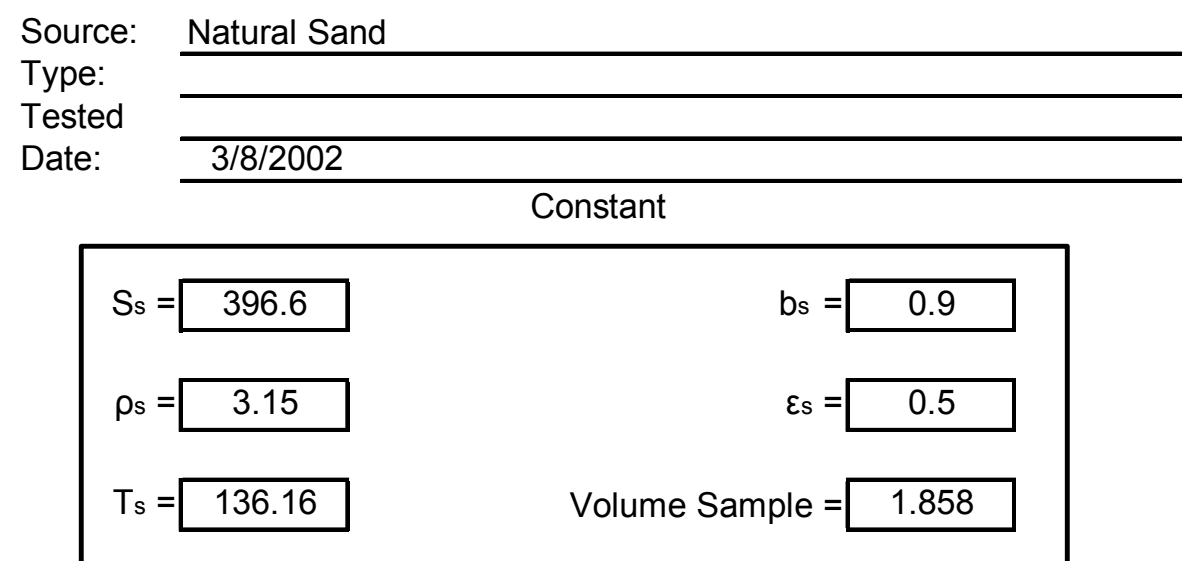

Temperature $=24 \quad$ S. G. (oven Dry Sample) $=2.522$

\begin{tabular}{|c|c|c|c|c|c|c|c|}
\hline Porosity & Weight of Sample & $\# 1$ & $\# 2$ & $\# 3$ & $\# 4$ & $\# 5$ & $\# 6$ \\
\hline 0.475 & 2.460 & 1.96 & 2.00 & 1.84 & 2.00 & 2.00 & 1.87 \\
\hline 0.462 & 2.519 & 2.09 & 2.09 & 2.11 & 2.13 & 2.14 & 2.21 \\
\hline 0.450 & 2.577 & 2.30 & 2.37 & 2.30 & 2.34 & 2.31 & 2.33 \\
\hline 0.437 & 2.636 & 2.50 & 2.50 & 2.66 & 2.50 & 2.63 & 2.53 \\
\hline
\end{tabular}

\begin{tabular}{|c|c|c|c|c|}
\hline Porosity & Weight of Sample & $\mathrm{T}$ & $\sqrt{\varepsilon^{3} T}$ & $\mathrm{~S}$ \\
\hline 0.475 & 2.460 & 1.95 & 0.457 & 7.259 \\
\hline 0.462 & 2.519 & 2.13 & 0.459 & 7.263 \\
\hline 0.450 & 2.577 & 2.33 & 0.460 & 7.259 \\
\hline 0.437 & 2.636 & 2.55 & 0.462 & 7.260 \\
\hline \multicolumn{6}{|c|}{ Correlation Coefficient $=0.9987>0.997$} \\
$\mathrm{~b}$
\end{tabular}

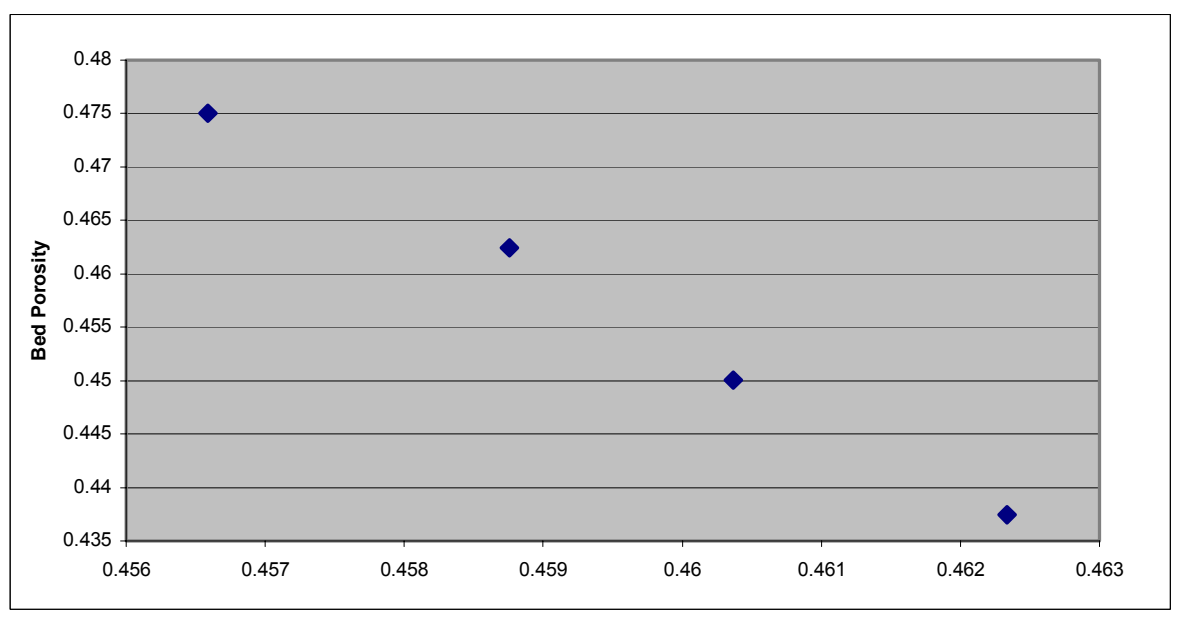




\section{APPENDIX C SURFACE AREA PAN MATERIAL}

\section{TABLE C.1 SUMMERSVILLE PAN MATERIAL SURFACE AREA}

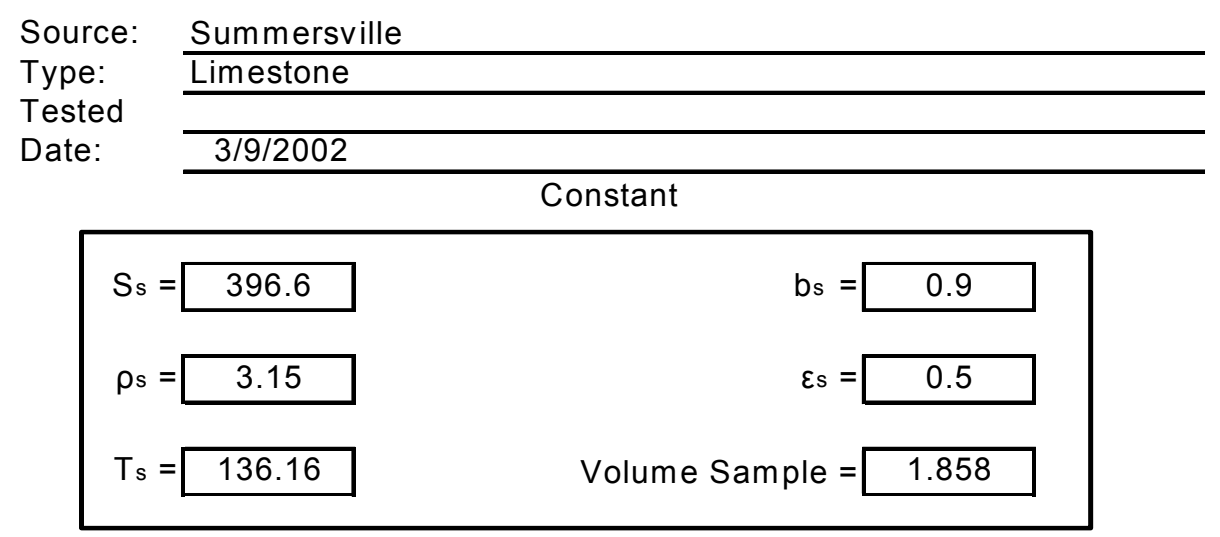
Temperature
24
S. G. (oven Dry Sample)
2.575

\begin{tabular}{|c|c|c|c|c|}
\hline Porosity & Weight of Sample & $\# 1$ & $\# 2$ & $\# 3$ \\
\hline 0.530 & 2.249 & 69.78 & 69.76 & 69.56 \\
\hline 0.500 & 2.392 & 99.65 & 98.71 & 100.00 \\
\hline 0.470 & 2.536 & 143.06 & 143.25 & 143.17 \\
\hline 0.440 & 2.679 & 195.00 & 195.28 & 195.56 \\
\hline
\end{tabular}

\begin{tabular}{|c|c|c|c|c|}
\hline Porosity & Weight of Sample & $\mathrm{T}$ & $\sqrt{\varepsilon^{3} T}$ & $\mathrm{~S}$ \\
\hline 0.530 & 2.249 & 69.70 & 3.221 & 456.050 \\
\hline 0.500 & 2.392 & 99.45 & 3.526 & 457.831 \\
\hline 0.470 & 2.536 & 143.16 & 3.855 & 462.322 \\
\hline 0.440 & 2.679 & 195.28 & 4.079 & 454.349 \\
$\quad b=0.862$ & \\
$\quad$ Correlation Coefficient $=$ & $0.9970 \quad>0.997$
\end{tabular}

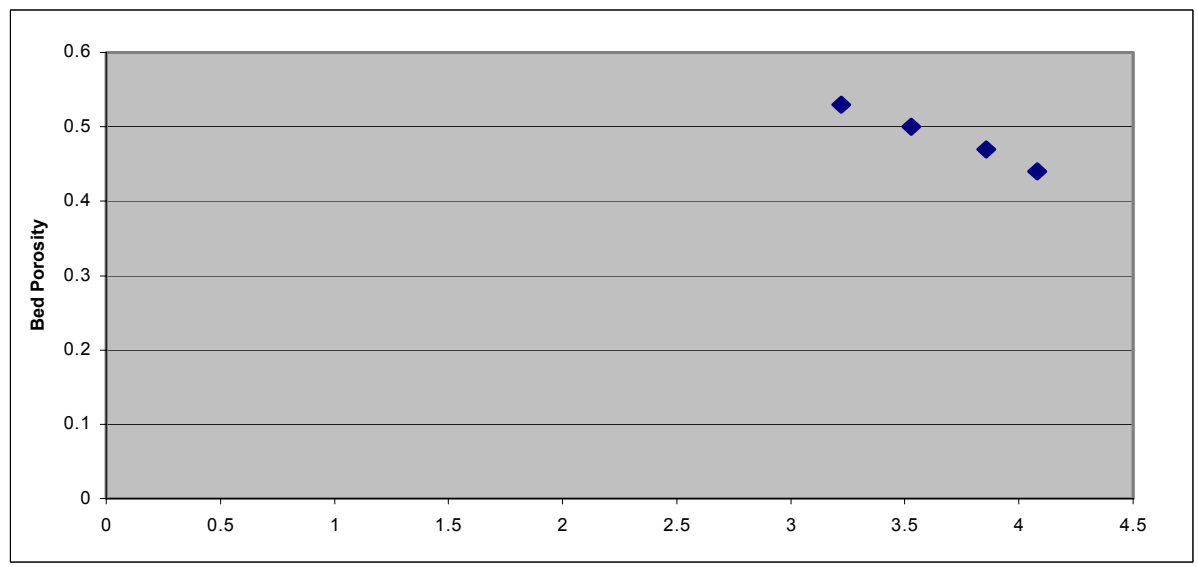


TABLE C.2 BEAVER BOXLEY SAMPLE (A) PAN MATERIAL SURFACE AREA

Source: Beaver Boxley (A)

$\begin{array}{ll}\text { Type: } & \text { Limestone } \\ \text { Tested } & \\ \text { Date: } & 3 / 10 / 2002 \quad \text { Constant }\end{array}$

\begin{tabular}{rr|}
\hline$s=396.6$ & $b_{s}=0.9$ \\
$\rho_{s}=3.15$ & $\varepsilon s=0.5$ \\
$T_{s}=136.16$ & Volume Sample $=1.858$
\end{tabular}

Temperature $=24 \quad$ S. G. (oven Dry Sample) $=2.62$

\begin{tabular}{|c|c|c|c|c|}
\hline Porosity & Weight of Sample & $\# 1$ & $\# 2$ & $\# 3$ \\
\hline 0.530 & 2.288 & 36.35 & 36.43 & 36.30 \\
\hline 0.500 & 2.434 & 54.75 & 54.12 & 54.53 \\
\hline 0.470 & 2.580 & 79.05 & 79.04 & 79.12 \\
\hline 0.440 & 2.726 & 118.75 & 118.50 & 118.93 \\
\hline
\end{tabular}

\begin{tabular}{|c|c|c|c|c|c|}
\hline Porosity & Weight of Sample & $\mathrm{T}$ & $\sqrt{\varepsilon^{3} T}$ & S & \\
\hline 0.530 & 2.288 & 36.36 & 2.327 & 435.584 & \\
\hline 0.500 & 2.434 & 54.47 & 2.609 & 435.585 & \\
\hline 0.470 & 2.580 & 79.07 & 2.865 & 431.557 & \\
\hline 0.440 & 2.726 & 118.73 & 3.180 & 436.355 & $b=0.777$ \\
\hline
\end{tabular}

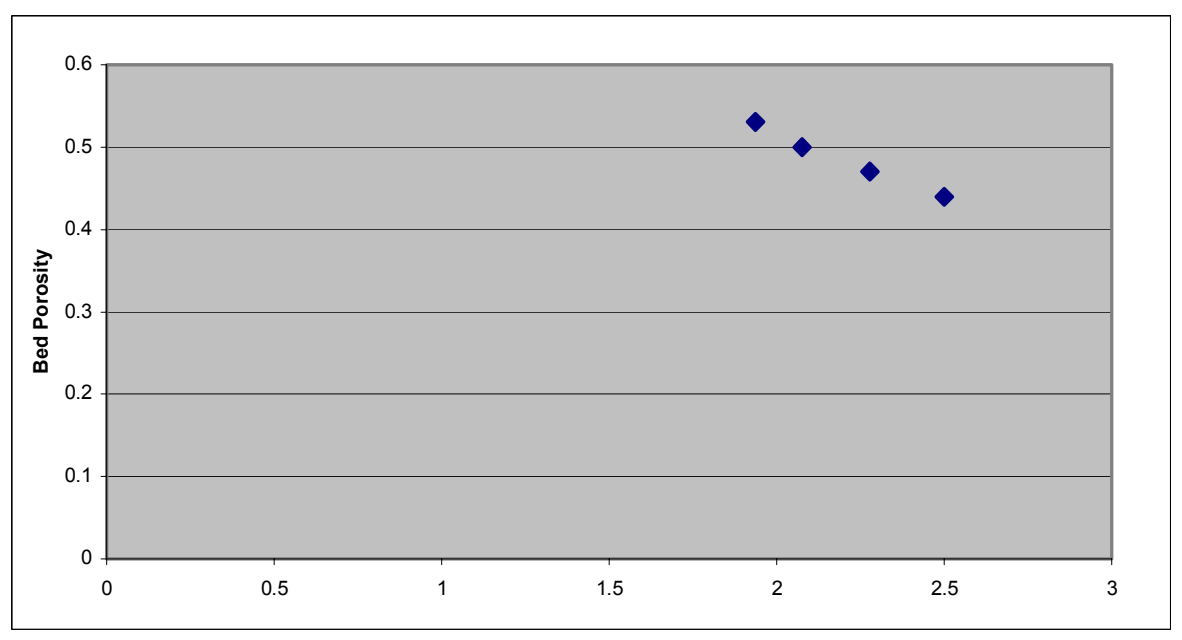


TABLE C.3 BEAVER BOXLEY SAMPLE (B) PAN MATERIAL SURFACE AREA

Source: Beaver Boxley (B)

Type: Limestone

Tested

Date:

$2 / 10 / 2002$

Constant

$\begin{array}{rlr}S_{s} & =396.6 \\ & b_{s}=0.9 \\ \rho_{s} & =3.15 \\ T_{s} & =136.16 \quad \text { Volume Sample }=1.858\end{array}$

Temperature $=24 \quad$ S. G. (oven Dry Sample) $=2.667$

\begin{tabular}{|c|c|c|c|c|}
\hline Porosity & Weight of Sample & $\# 1$ & $\# 2$ & $\# 3$ \\
\hline 0.530 & 2.329 & $25 . .22$ & 25.43 & 24.97 \\
\hline 0.500 & 2.478 & 34.56 & 34.39 & 34.53 \\
\hline 0.470 & 2.626 & 50.00 & 50.00 & 50.00 \\
\hline 0.440 & 2.775 & 40.00 & 90.00 & 90.00 \\
\hline
\end{tabular}

\begin{tabular}{|c|c|c|c|c|}
\hline Porosity & Weight of Sample & $\mathrm{T}$ & $\sqrt{\varepsilon^{3} T}$ & $\mathrm{~S}$ \\
\hline 0.530 & 2.329 & 25.20 & 1.937 & 292.648 \\
\hline 0.500 & 2.478 & 34.49 & 2.076 & 285.260 \\
\hline 0.470 & 2.626 & 50.00 & 2.278 & 286.964 \\
\hline 0.440 & 2.775 & 73.33 & 2.499 & 290.615
\end{tabular}$\quad \mathrm{~b}=0.831 \quad>0.9951 \quad>097$

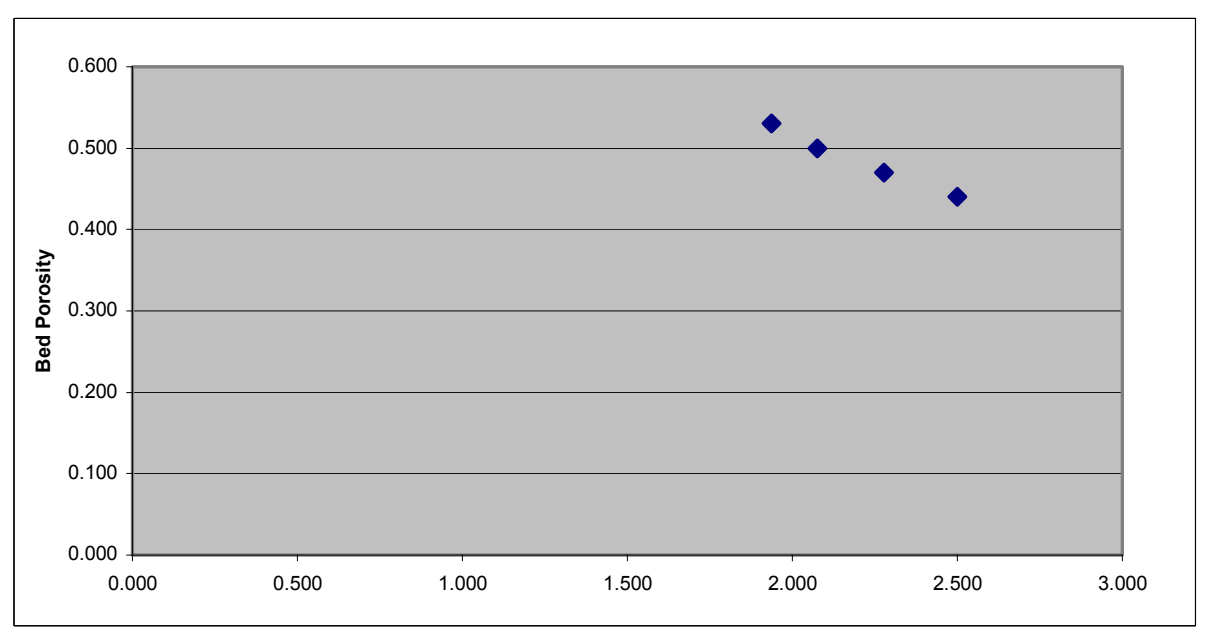


TABLE C.4 APAC SAMPLE \#1PAN MATERIAL SURFACE AREA

Source: $\quad$ APAC sample \#1

\begin{tabular}{ll} 
Type: & Limestone \\
Tested & \\
Date: & $3 / 11 / 2002$ \\
\cline { 2 - 2 } &
\end{tabular}

\begin{tabular}{rr|}
$S_{s}=396.6$ & $b s=0.9$ \\
$\rho_{s}=3.15$ & $\varepsilon s=0.5$ \\
$T_{s}=136.16$ & Volume Sample $=1.858$
\end{tabular}

Temperature $=24 \quad$ S. G. (oven Dry Sample) $=2.603$

\begin{tabular}{|c|c|c|c|c|}
\hline Porosity & Weight of Sample & $\# 1$ & $\# 2$ & $\# 3$ \\
\hline 0.530 & 2.273 & 67.87 & 67.81 & 67.93 \\
\hline 0.500 & 2.418 & 95.18 & 97.00 & 97.18 \\
\hline 0.470 & 2.563 & 137.00 & 134.15 & 135.68 \\
\hline 0.440 & 2.708 & 190.18 & 190.75 & 189.46 \\
\hline
\end{tabular}

\begin{tabular}{|c|c|c|c|c|c|}
\hline Porosity & Weight of Sample & $\mathrm{T}$ & $\sqrt{\varepsilon^{3} T}$ & $\mathrm{~S}$ \\
\hline 0.530 & 2.273 & 67.87 & 3.179 & 436.341 \\
\hline 0.500 & 2.418 & 96.45 & 3.472 & 437.885 \\
\hline 0.470 & 2.563 & 135.61 & 3.752 & 437.615 \\
\hline 0.440 & 2.708 & 190.13 & 4.024 & 436.535
\end{tabular}$\quad \begin{array}{r}\mid \\
\text { Correlation Coefficient }=0.9999 \quad>0.997\end{array}$

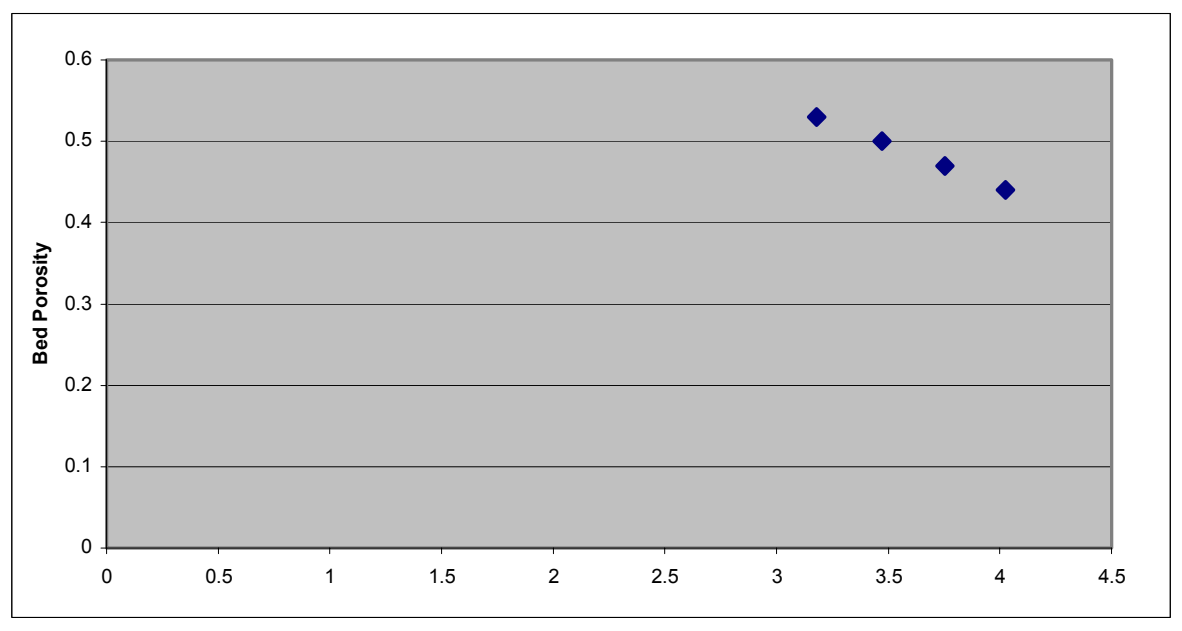




\section{TABLE C.5 APAC SAMPLE \#2 PAN MATERIAL SURFACE AREA}

Source: $\quad$ APAC sample \#2

\begin{tabular}{ll} 
Type: & Limestone \\
Tested & \\
Date: & $3 / 12 / 2002$ \\
\cline { 2 - 3 } &
\end{tabular}

\begin{tabular}{rr|}
$S_{s}=396.6$ & $b_{s}=0.9$ \\
$\rho_{s}=3.15$ & $\varepsilon_{s}=0.5$ \\
$T_{s}=136.16$ & Volume Sample $=1.858$
\end{tabular}

Temperature $=24 \quad$ S. G. (oven Dry Sample) $=2.684$

\begin{tabular}{|c|c|c|c|c|}
\hline Porosity & Weight of Sample & $\# 1$ & $\# 2$ & $\# 3$ \\
\hline 0.530 & 2.344 & 145.92 & 145.46 & 145.37 \\
\hline 0.500 & 2.493 & 194.31 & 193.96 & 194.75 \\
\hline 0.470 & 2.643 & 266.14 & 264.15 & 264.27 \\
\hline 0.440 & 2.793 & 369.15 & 368.43 & 369.03 \\
\hline
\end{tabular}

\begin{tabular}{|c|c|c|c|c|}
\hline Porosity & Weight of Sample & $\mathrm{T}$ & $\sqrt{\varepsilon^{3} T}$ & $\mathrm{~S}$ \\
\hline 0.530 & 2.344 & 145.58 & 4.656 & 480.438 \\
\hline 0.500 & 2.493 & 194.34 & 4.929 & 475.980 \\
\hline 0.470 & 2.643 & 264.85 & 5.244 & 475.861 \\
\hline 0.440 & 2.793 & 368.87 & 5.606 & 479.742
\end{tabular}$\quad \mathrm{~b}=0.967 \quad$ Correlation Coefficient $=0.9981 \quad>0.997$

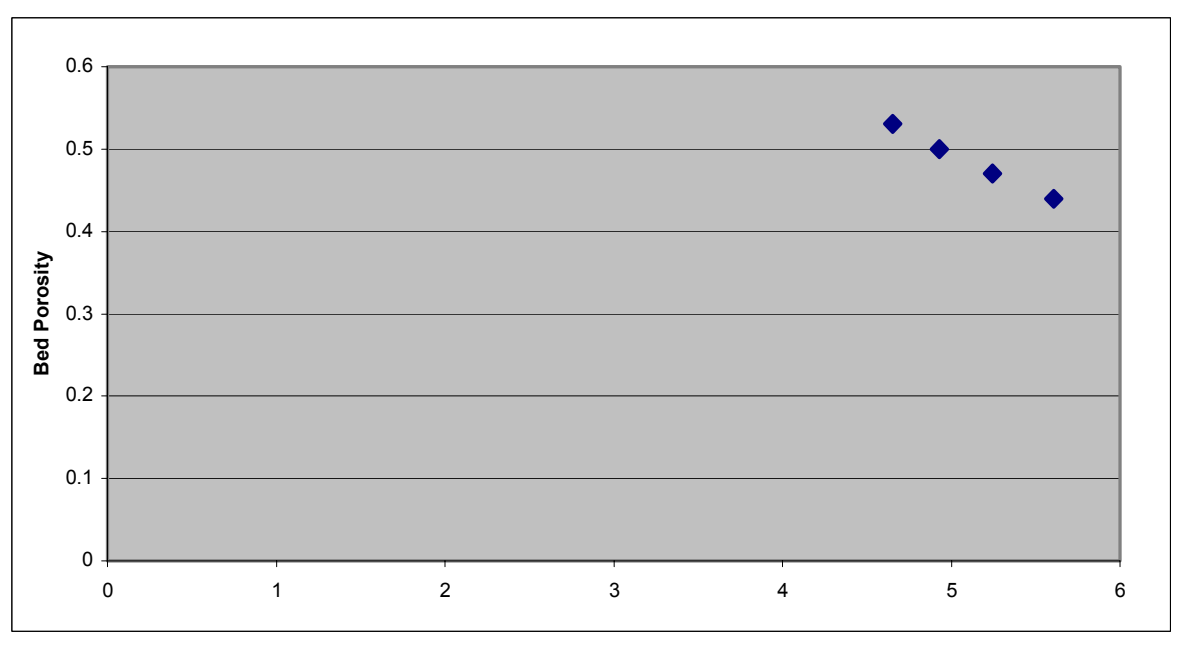




\section{TABLE C.6 NEW ENTERPRISE PAN MATERIAL SURFACE AREA}

Source: New Enterprise

\begin{tabular}{ll} 
Type: & Limestone \\
Tested & \\
Date: & $3 / 13 / 2002$ \\
\cline { 2 - 3 } &
\end{tabular}

\begin{tabular}{|c|c|c|}
\hline$S_{s}=396.6$ & $b_{s}=$ & 0.9 \\
\hline 3.15 & $\varepsilon_{\mathrm{s}}=$ & 0.5 \\
\hline$=136.16$ & Volume Sample $=$ & 1.858 \\
\hline
\end{tabular}

Temperature $=24$

S. G. (oven Dry Sample) $=2.523$

\begin{tabular}{|c|c|c|c|c|}
\hline Porosity & Weight of Sample & $\# 1$ & $\# 2$ & $\# 3$ \\
\hline 0.530 & 2.203 & 25.50 & 25.62 & 26.37 \\
\hline 0.500 & 2.344 & 39.53 & 39.87 & 37.15 \\
\hline 0.470 & 2.484 & 71.84 & 73.21 & 72.25 \\
\hline 0.440 & 2.625 & 108.34 & 108.21 & 107.56 \\
\hline
\end{tabular}

\begin{tabular}{|c|c|c|c|c|c|}
\hline Porosity & Weight of Sample & $\mathrm{T}$ & $\sqrt{\varepsilon^{3} T}$ & $\mathrm{~S}$ \\
\hline 0.530 & 2.203 & 25.83 & 1.961 & 630.834 \\
\hline 0.500 & 2.344 & 38.85 & 2.204 & 590.255 \\
\hline 0.470 & 2.484 & 72.43 & 2.742 & 629.211 \\
\hline 0.440 & 2.625 & 108.04 & 3.034 & 608.773
\end{tabular}$\quad \mathrm{~b}=0.679 \quad \begin{gathered} \\
\text { Correlation Coefficient }=0.9893 \quad>0.997\end{gathered}$

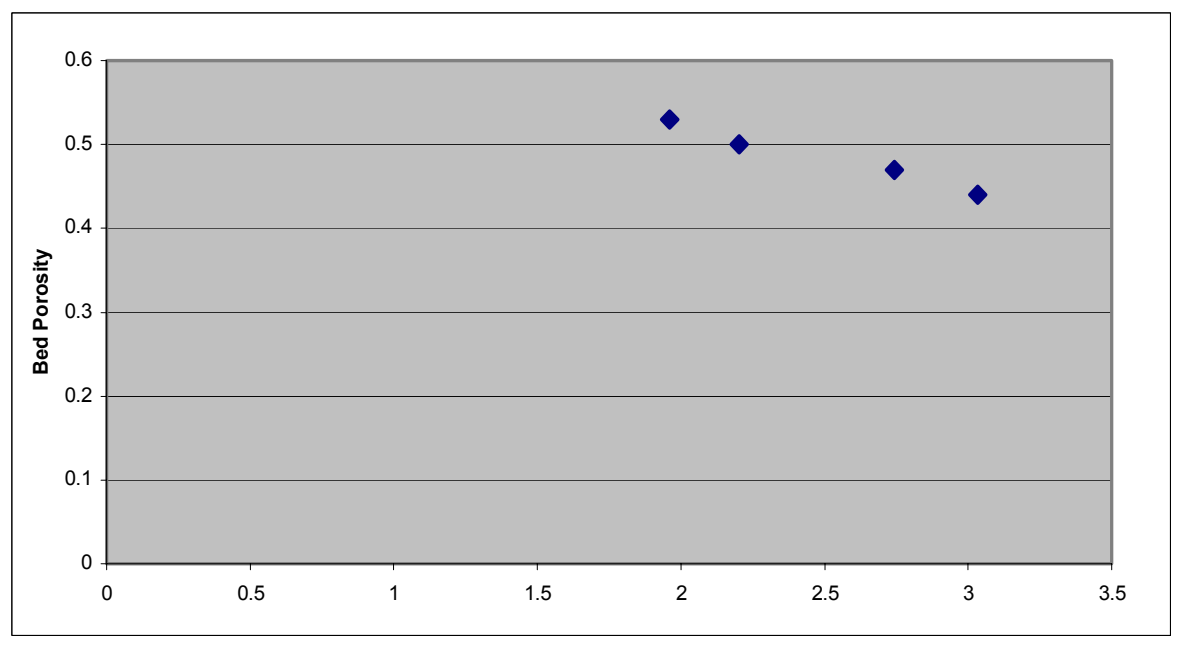




\section{TABLE C.7 NATURAL SAND PAN MATERIAL SURFACE AREA}

Source: Natural Sand

Type:

Tested

Date:

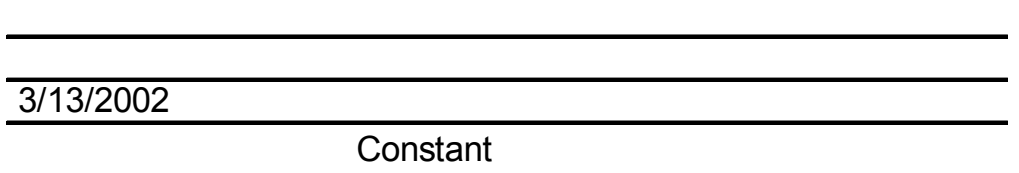

\begin{tabular}{|c|c|c|c|}
\hline$S_{s}=$ & 396.6 & $b_{s}=$ & 0.9 \\
\hline$\rho s=$ & 3.15 & $\varepsilon_{\mathrm{s}}=$ & 0.5 \\
\hline $\mathrm{T}_{\mathrm{s}}=$ & 136.16 & Volume Sample $=$ & 1.858 \\
\hline
\end{tabular}

Temperature $=24$ S. G. (oven Dry Sample) $=2.522$

\begin{tabular}{|c|c|c|c|c|}
\hline Porosity & Weight of Sample & $\# 1$ & $\# 2$ & $\# 3$ \\
\hline 0.500 & 2.343 & 16.86 & 17.15 & 17.46 \\
\hline 0.470 & 2.484 & 23.28 & 22.93 & 22.81 \\
\hline 0.440 & 2.624 & 30.90 & 30.96 & 31,71 \\
\hline 0.410 & 2.765 & 40.96 & 41.15 & 41.37 \\
\hline
\end{tabular}

\begin{tabular}{|c|c|c|c|c|}
\hline Porosity & Weight of Sample & $\mathrm{T}$ & $\sqrt{\varepsilon^{3} T}$ & $\mathrm{~S}$ \\
\hline 0.500 & 2.343 & 17.16 & 1.464 & 118.176 \\
\hline 0.470 & 2.484 & 23.01 & 1.546 & 118.734 \\
\hline 0.440 & 2.624 & 30.93 & 1.623 & 118.991 \\
\hline 0.410 & 2.765 & 41.16 & 1.684 & 118.063 \\
Correlation Coefficient $=0.9980 \quad \mathrm{~b}=0.997$
\end{tabular}

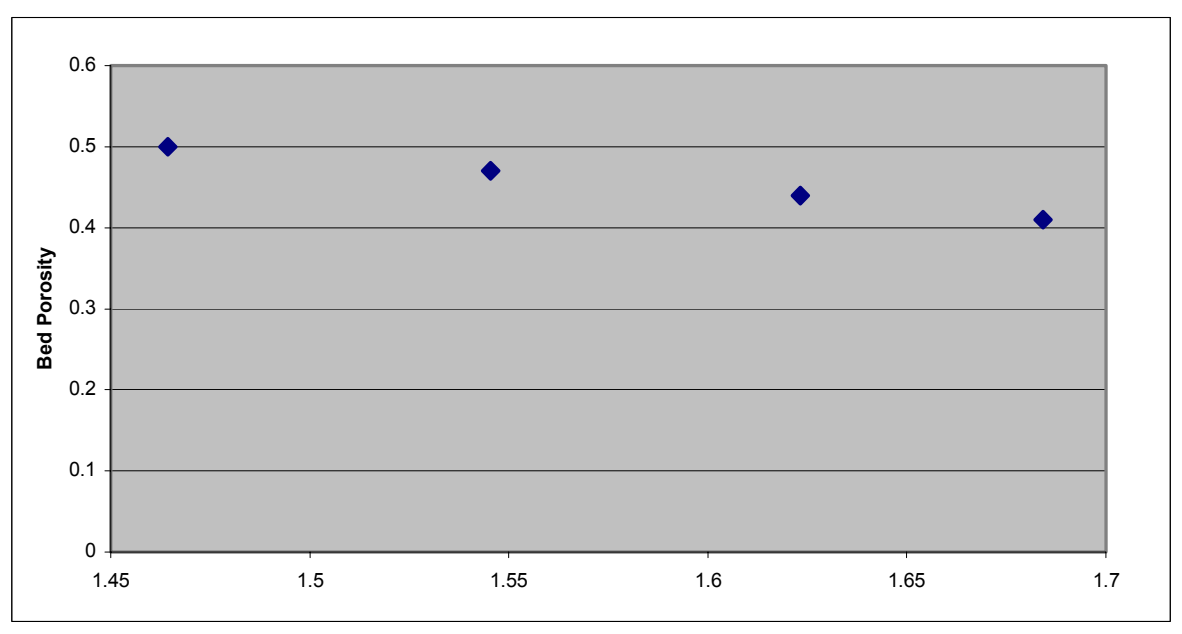




\section{APPENDIX D BAGHOUSE FINES SPECIFIC SURFACE AREAS}

\section{TABLE D.1 SUMMERSVILLE BAGHOUSE FINES SPECIFIC SURFACE AREA}

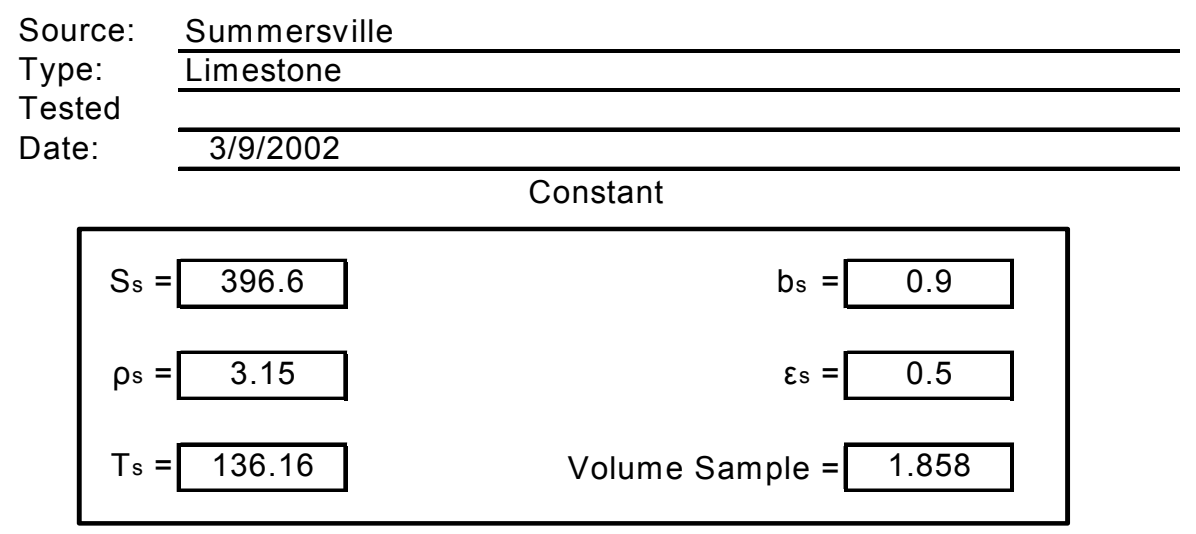

Temperature $=24$ S. G. (oven Dry Sample) $=2.575$

\begin{tabular}{|c|c|c|c|c|}
\hline \multicolumn{5}{|c|}{ Time } \\
\hline Porosity & Weight of Sample & $\# 1$ & $\# 2$ & $\# 3$ \\
\hline 0.530 & 2.249 & 69.78 & 69.76 & 69.56 \\
\hline 0.500 & 2.392 & 99.65 & 98.71 & 100.00 \\
\hline 0.470 & 2.536 & 143.06 & 143.25 & 143.17 \\
\hline 0.440 & 2.679 & 195.00 & 195.28 & 195.56 \\
\hline
\end{tabular}

\begin{tabular}{|c|c|c|c|c|c|}
\hline Porosity & Weight of Sample & $\mathrm{T}$ & $\sqrt{\varepsilon^{3} T}$ & $\mathrm{~S}$ & \\
\hline 0.530 & 2.249 & 69.70 & 3.221 & 456.050 & \\
\hline 0.500 & 2.392 & 99.45 & 3.526 & 457.831 & \\
\hline 0.470 & 2.536 & 143.16 & 3.855 & 462.322 & \\
\hline 0.440 & 2.679 & 195.28 & 4.079 & 454.349 & $b=0.862$ \\
\hline
\end{tabular}

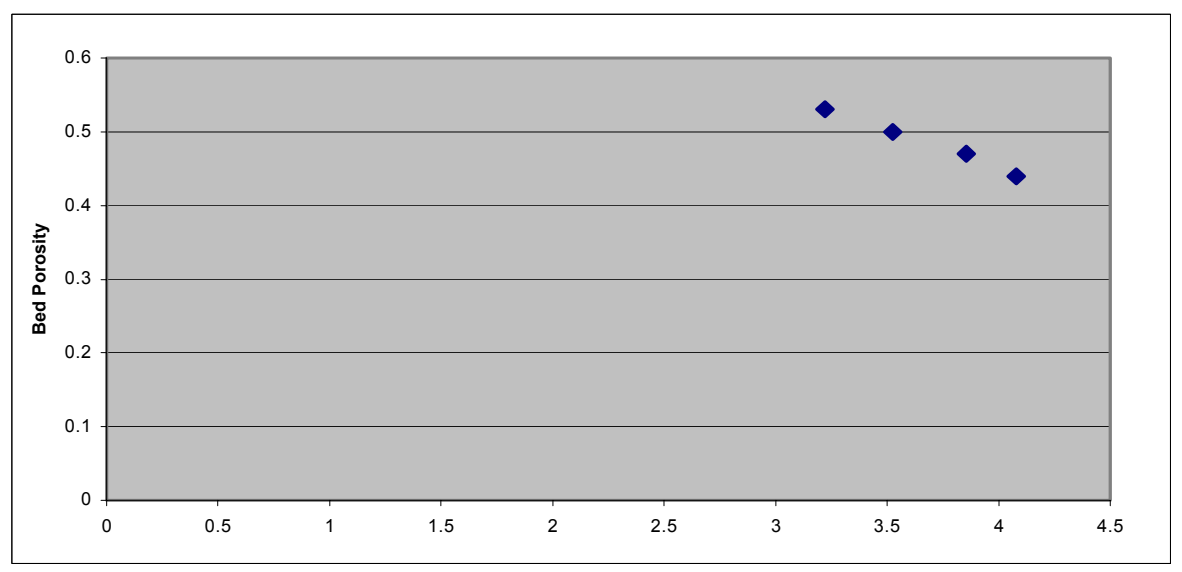




\section{TABLE D.2 GASAWAY BAGHOUSE FINES SPECIFIC SURFACE AREA.}

Source: Gasaway

Type: Baghouse Fines

Tested

Date: $\quad 3 / 16 / 2002$

Constant

\begin{tabular}{|c|c|c|c|}
\hline$S_{s}=$ & 396.6 & $b_{s}=$ & 0.9 \\
\hline$\rho_{\mathrm{s}}=$ & 3.15 & $\varepsilon_{\mathrm{s}}=$ & 0.5 \\
\hline$T_{s}=[$ & 136.16 & Volume Sample $=$ & 1.858 \\
\hline
\end{tabular}

Temperature $=24 \quad$ S. G. (oven Dry Sample) $=2.712$

\begin{tabular}{|c|c|c|c|c|}
\hline Porosity & Weight of Sample & $\# 1$ & $\# 2$ & $\# 3$ \\
\hline 0.530 & 2.368 & 81.75 & 85.78 & 81.40 \\
\hline 0.500 & 2.519 & 118.03 & 117.71 & 115.81 \\
\hline 0.470 & 2.670 & 172.62 & 173.03 & 170.53 \\
\hline 0.440 & 2.822 & 255.06 & 256.21 & 254.18 \\
\hline
\end{tabular}

\begin{tabular}{|c|c|c|c|c|c|}
\hline Porosity & Weight of Sample & $\mathrm{T}$ & $\sqrt{\varepsilon^{3} T}$ & S & \\
\hline 0.530 & 2.368 & 82.98 & 3.515 & 579.558 & \\
\hline 0.500 & 2.519 & 117.18 & 3.828 & 568.297 & \\
\hline 0.470 & 2.670 & 172.06 & 4.228 & 570.812 & \\
\hline 0.440 & 2.822 & 255.15 & 4.661 & 576.705 & $b=0.801$ \\
\hline
\end{tabular}

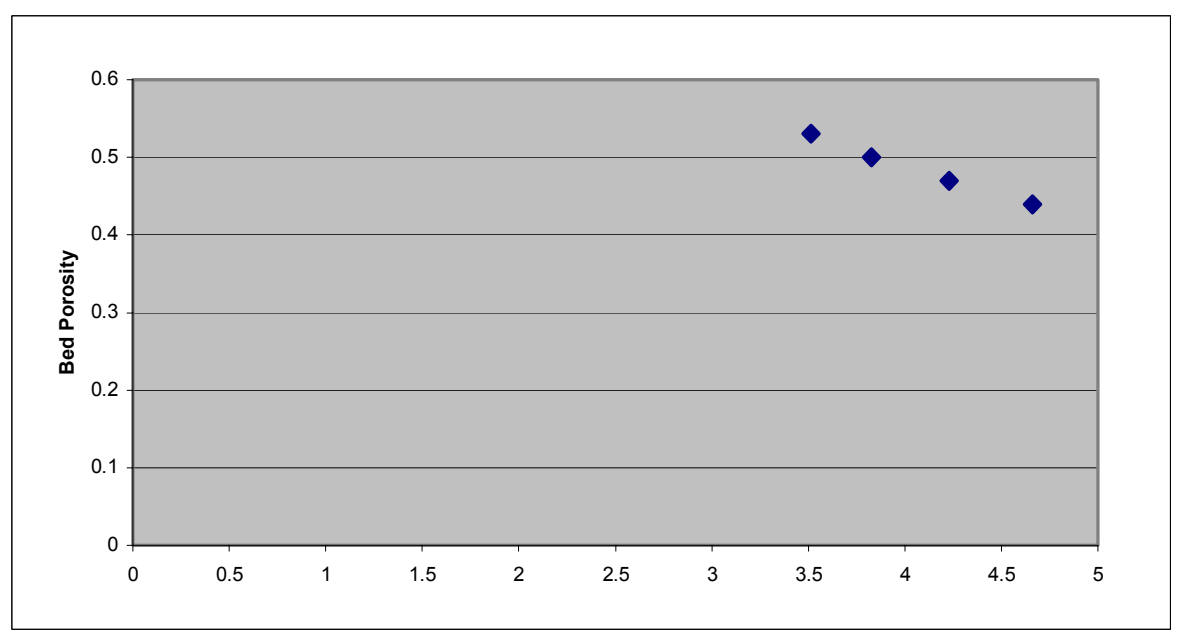


TABLE D.3 BEAVER BOXLEY BAGHOUSE FINE SAMPLE (A) SPECIFIC SURFACE AREA

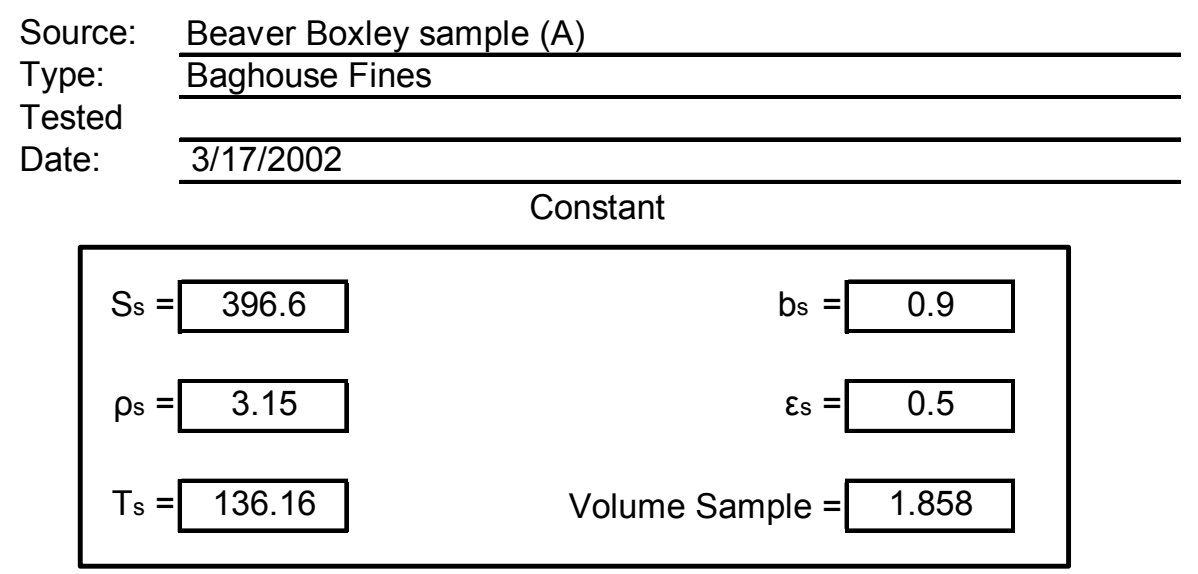

Temperature $=24 \quad$ S. G. (oven Dry Sample) $=2.672$

\begin{tabular}{|c|c|c|c|c|}
\hline Porosity & Weight of Sample & $\# 1$ & $\# 2$ & $\# 3$ \\
\hline 0.530 & 2.333 & 457.81 & 446.81 & 464.65 \\
\hline 0.500 & 2.482 & 664.90 & 680.50 & 667.43 \\
\hline 0.470 & 2.631 & 935.37 & 947.03 & 942.34 \\
\hline 0.440 & 2.780 & 1334.23 & 1328.46 & 1330.35 \\
\hline
\end{tabular}

\begin{tabular}{|c|c|c|c|c|c|}
\hline Porosity & Weight of Sample & $\mathrm{T}$ & $\sqrt{\varepsilon^{3} T}$ & $\mathrm{~S}$ \\
\hline 0.530 & 2.333 & 456.42 & 8.245 & 1196.068 \\
\hline 0.500 & 2.482 & 670.94 & 9.160 & 1212.319 \\
\hline 0.470 & 2.631 & 941.58 & 9.889 & 1203.376 \\
\hline 0.440 & 2.780 & 1331.01 & 10.649 & 1199.306
\end{tabular}$\quad \mathrm{~b}=0.843 \quad \begin{aligned} & \\
& \text { Correlation Coefficient }=0.9987 \quad>0.997\end{aligned}$

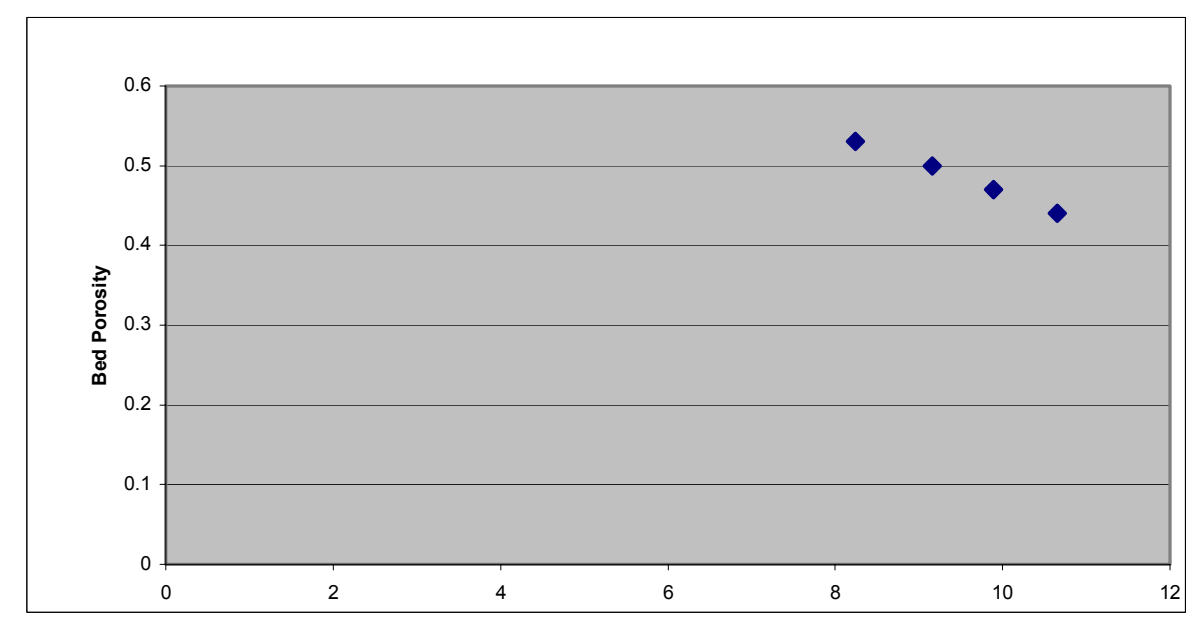


TABLE D.4 BEAVER BOXLEY BAGHOUSE FINES SAMPLE (B) SPECIFIC SURFACE AREA

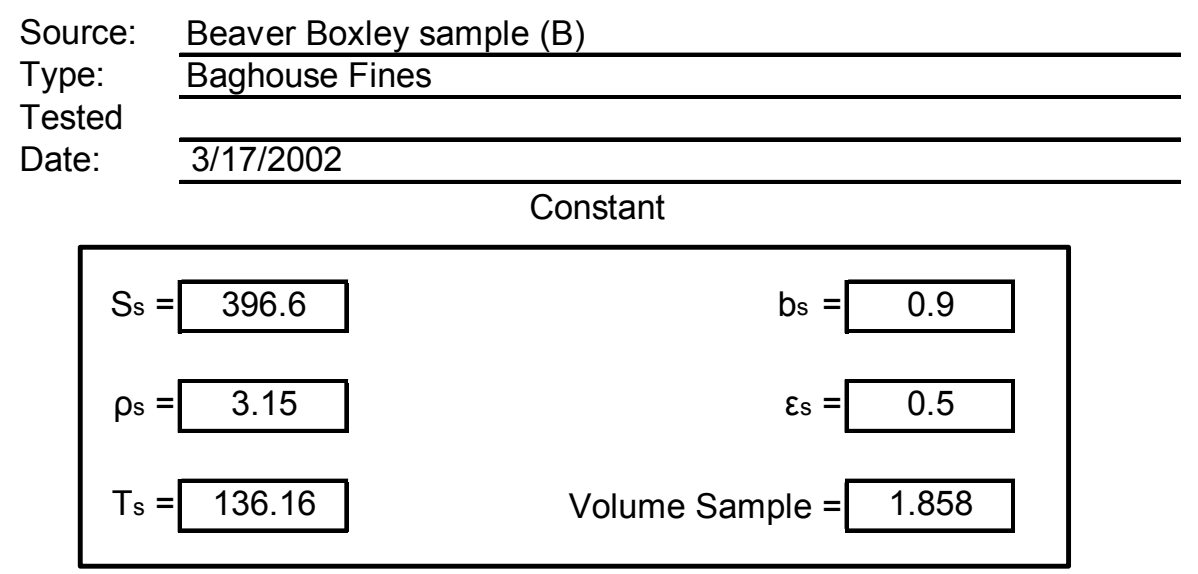

Temperature $=24 \quad$ S. G. (oven Dry Sample) $=2.687$

\begin{tabular}{|c|c|c|c|c|}
\hline Porosity & Weight of Sample & $\# 1$ & $\# 2$ & $\# 3$ \\
\hline 0.533 & 2.333 & 234.20 & 216.28 & 226.24 \\
\hline 0.503 & 2.482 & 326.87 & 312.40 & 320.64 \\
\hline 0.473 & 2.631 & 496.53 & 431.87 & 463.30 \\
\hline 0.443 & 2.780 & 640.18 & 631.43 & 636.81 \\
\hline
\end{tabular}

\begin{tabular}{|c|c|c|c|c|}
\hline Porosity & Weight of Sample & $\mathrm{T}$ & $\sqrt{\varepsilon^{3} T}$ & $\mathrm{~S}$ \\
\hline 0.533 & 2.333 & 225.57 & 5.839 & 823.137 \\
\hline 0.503 & 2.482 & 319.97 & 6.378 & 822.380 \\
\hline 0.473 & 2.631 & 463.90 & 7.007 & 832.332 \\
\hline 0.443 & 2.780 & 636.14 & 7.441 & 819.451 \\
\hline \multicolumn{6}{|c|}{ Correlation Coefficient $=0.9977 \quad>0.997$} \\
$\mathrm{~b}$
\end{tabular}

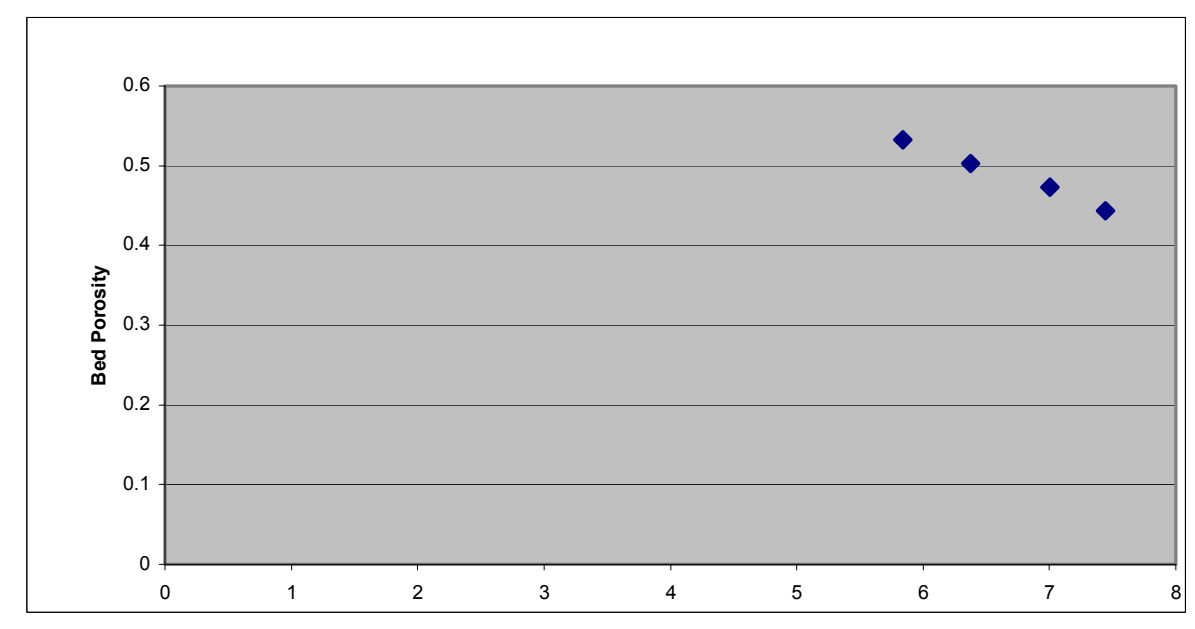




\section{TABLE D.5 APAC BAGHOUSE FINE SPECIFIC SURFACE AREA}

Source: $\quad$ APAC sample \#1

Type: Baghouse Fines

Tested

Date: $3 / 18 / 2002$

Constant

\begin{tabular}{|c|c|c|c|}
\hline$S_{s}=$ & 396.6 & $b_{s}=$ & 0.9 \\
\hline$\rho s=$ & 3.15 & $\varepsilon s=$ & 0.5 \\
\hline $\mathrm{T}_{\mathrm{s}}=$ & 136.16 & Volume Sample = & 1.858 \\
\hline
\end{tabular}

Temperature $=24$

S. G. (oven Dry Sample) $=2.707$

\begin{tabular}{|c|c|c|c|c|}
\hline Porosity & Weight of Sample & $\# 1$ & $\# 2$ & $\# 3$ \\
\hline 0.560 & 2.213 & 194.62 & 191.62 & 187.43 \\
\hline 0.530 & 2.364 & 272.34 & 269.31 & 268.40 \\
\hline 0.500 & 2.515 & 378.37 & 370.37 & 382.28 \\
\hline 0.480 & 2.615 & 458.56 & 458.34 & 450.45 \\
\hline
\end{tabular}

\begin{tabular}{|c|c|c|c|c|c|}
\hline Porosity & Weight of Sample & $\mathrm{T}$ & $\sqrt{\varepsilon^{3} T}$ & $\mathrm{~S}$ \\
\hline 0.560 & 2.213 & 191.22 & 5.795 & 743.015 \\
\hline 0.530 & 2.364 & 270.02 & 6.340 & 748.492 \\
\hline 0.500 & 2.515 & 377.01 & 6.864 & 750.880 \\
\hline 0.480 & 2.615 & 455.78 & 7.101 & 740.844
\end{tabular}$\quad \mathrm{~b}=0.909 \quad \begin{aligned} & \\
& \text { Correlation Coefficient }=0.9973 \quad>0.997\end{aligned}$

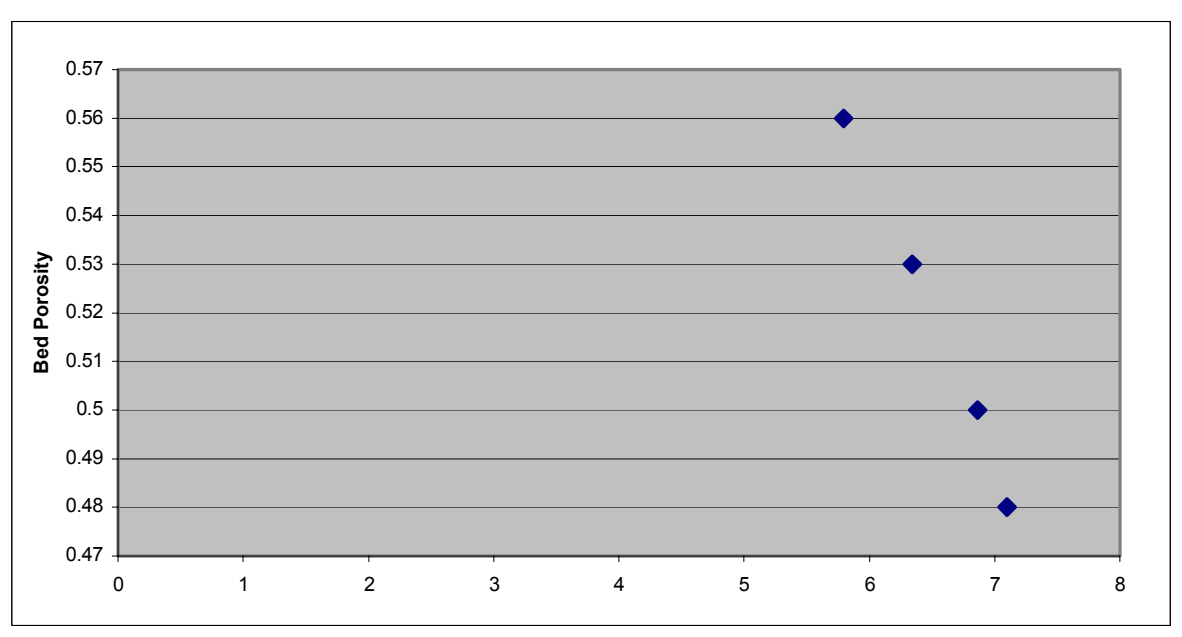




\section{TABLE D.6 J.F. ALLEN BAGHOUSE FINES SPECIFIC SURFACE AREA}

Source: JFA

Type: $\quad$ Baghouse Fines

Tested

Date: $\quad 2 / 18 / 2002$

Constant

\begin{tabular}{|c|c|c|c|}
\hline $\mathrm{S}_{\mathrm{s}}=$ & 396.6 & $b_{s}=$ & 0.9 \\
\hline$\rho_{s}=$ & 3.15 & $\varepsilon_{\mathrm{s}}=$ & 0.5 \\
\hline $\mathrm{T}_{\mathrm{s}}=$ & 136.16 & Volume Sample $=$ & 1.858 \\
\hline
\end{tabular}

Temperature $=24 \quad$ S. G. (oven Dry Sample) $=2.588$

\begin{tabular}{|c|c|c|c|c|}
\hline Porosity & Weight of Sample & $\# 1$ & $\# 2$ & $\# 3$ \\
\hline 0.540 & 2.213 & 180.99 & 181.62 & 181.79 \\
\hline 0.508 & 2.364 & 271.20 & 271.31 & 271.16 \\
\hline 0.477 & 2.515 & 374.96 & 375.39 & 374.80 \\
\hline 0.456 & 2.615 & 470.87 & 471.34 & 471.09 \\
\hline
\end{tabular}

\begin{tabular}{|c|c|c|c|c|c|}
\hline Porosity & Weight of Sample & $T$ & $\sqrt{\varepsilon^{3} T}$ & $S$ & \\
\hline 0.540 & 2.213 & 181.47 & 5.342 & 741.503 & \\
\hline 0.508 & 2.364 & 271.22 & 5.969 & 757.985 & \\
\hline 0.477 & 2.515 & 375.05 & 6.379 & 746.443 & \\
\hline 0.456 & 2.615 & 471.10 & 6.687 & 743.798 & $b=0.877$ \\
\hline
\end{tabular}

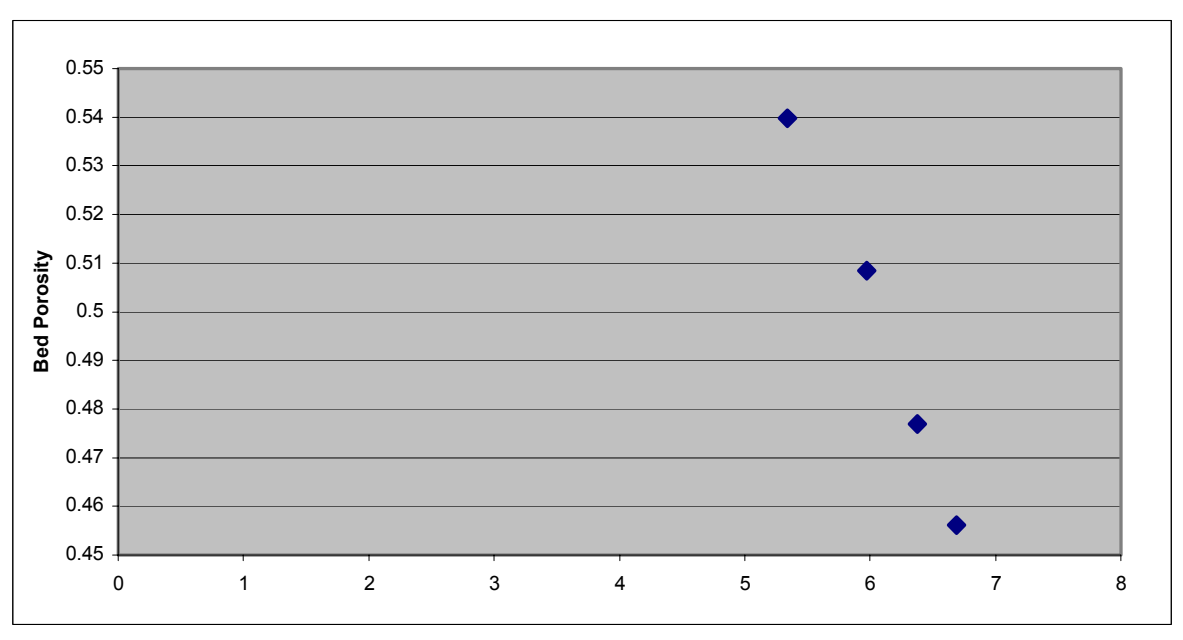


TABLE D.7 NEW ENTERPRISE BAGHOUSE FINES SPECIFIC SURFACE AREA

$\begin{array}{ll}\text { Source: } & \text { New Enterprise } \\ \text { Type: } & \text { Baghouse Fines } \\ \text { Tested } & \\ \text { Date: } & 3 / 19 / 2002 \\ & \end{array}$

$\begin{aligned} S_{s} & =396.6 & b_{s} & =0.9 \\ \rho_{s} & =3.15 & \varepsilon_{s} & =0.5 \\ T_{s} & =136.16 & \text { Volume Sample } & =1.858\end{aligned}$

Temperature $=24$

S. G. (oven Dry Sample) $=2.706$

\begin{tabular}{|c|c|c|c|c|}
\hline Porosity & Weight of Sample & $\# 1$ & $\# 2$ & $\# 3$ \\
\hline 0.562 & 2.204 & 74.81 & 75.28 & 70,05 \\
\hline 0.534 & 2.344 & 99.68 & 104.78 & 104.06 \\
\hline 0.506 & 2.485 & 140.56 & 136.59 & 145.58 \\
\hline 0.478 & 2.626 & 196.96 & 191.50 & 195.23 \\
\hline
\end{tabular}

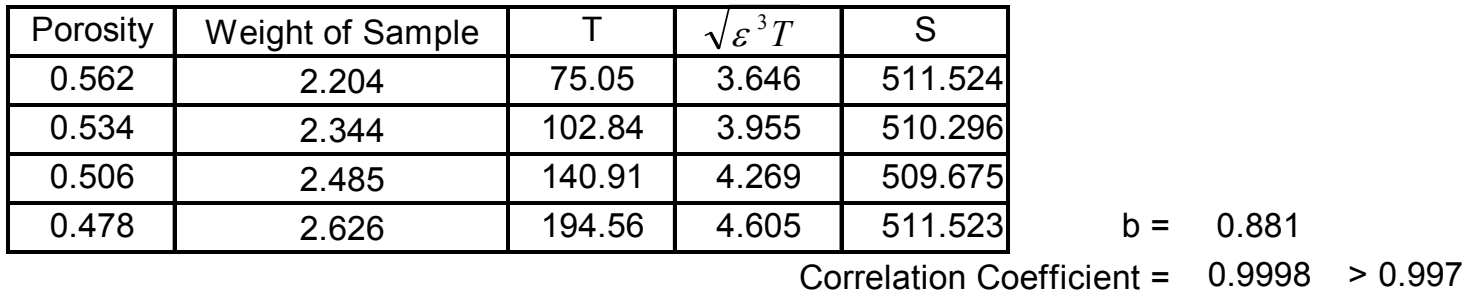

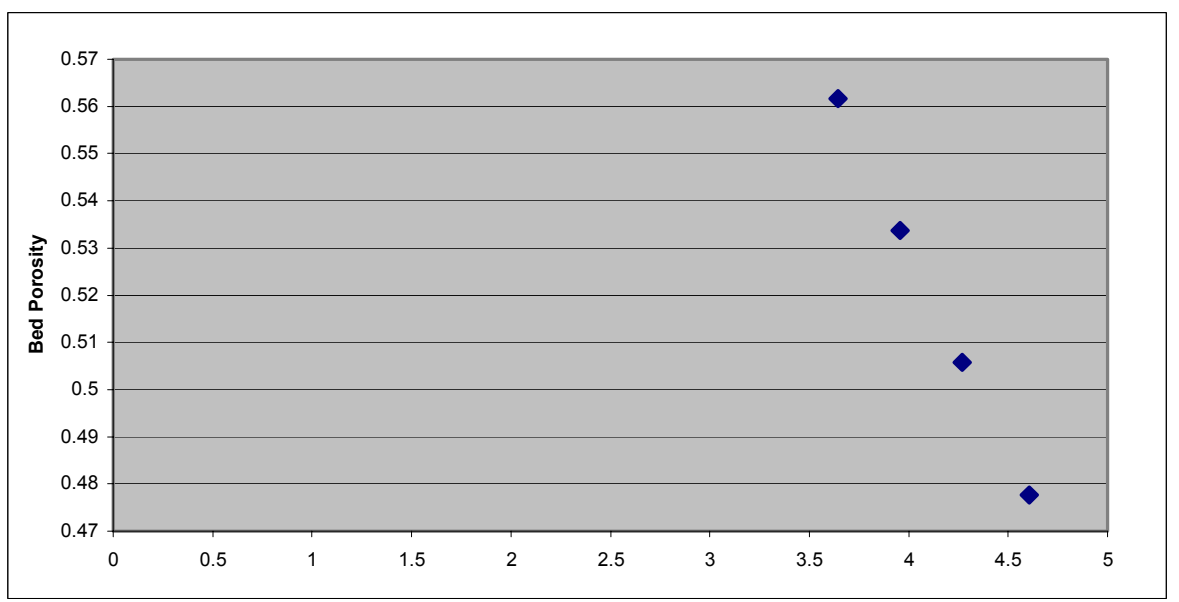




\section{TABLE D.8 W.V. PAVING BAGHOUSE FINES SPECIFIC SURFACE AREA}

Source: W.V. Paving

Type: $\quad$ Baghouse Fines

Tested

Date: $\quad 3 / 19 / 2002$

Constant

\begin{tabular}{|c|c|c|c|}
\hline$S_{s}=$ & 396.6 & $b_{s}=$ & 0.9 \\
\hline$\rho_{s}=$ & 3.15 & $\varepsilon_{\mathrm{s}}=$ & 0.5 \\
\hline$T_{s}=$ & 136.16 & Volume Sample $=$ & 1.858 \\
\hline
\end{tabular}

Temperature $=24$ S. G. (oven Dry Sample) $=2.686$

\begin{tabular}{|c|c|c|c|c|}
\hline Porosity & Weight of Sample & $\# 1$ & $\# 2$ & $\# 3$ \\
\hline 0.530 & 2.346 & 112.34 & 119.31 & 119.59 \\
\hline 0.500 & 2.495 & 163.06 & 165.55 & 161.37 \\
\hline 0.470 & 2.645 & 242.53 & 235.34 & 232.78 \\
\hline 0.440 & 2.795 & 335.34 & 345.65 & 344.12 \\
\hline
\end{tabular}

\begin{tabular}{|c|c|c|c|c|c|}
\hline Porosity & Weight of Sample & $T$ & $\sqrt{\varepsilon^{3} T}$ & $S$ & \\
\hline 0.530 & 2.346 & 117.08 & 4.175 & 622.970 & \\
\hline 0.500 & 2.495 & 163.33 & 4.518 & 613.328 & \\
\hline 0.470 & 2.645 & 236.88 & 4.959 & 617.415 & \\
\hline 0.440 & 2.795 & 341.70 & 5.395 & 620.311 & 0.832 \\
\hline
\end{tabular}

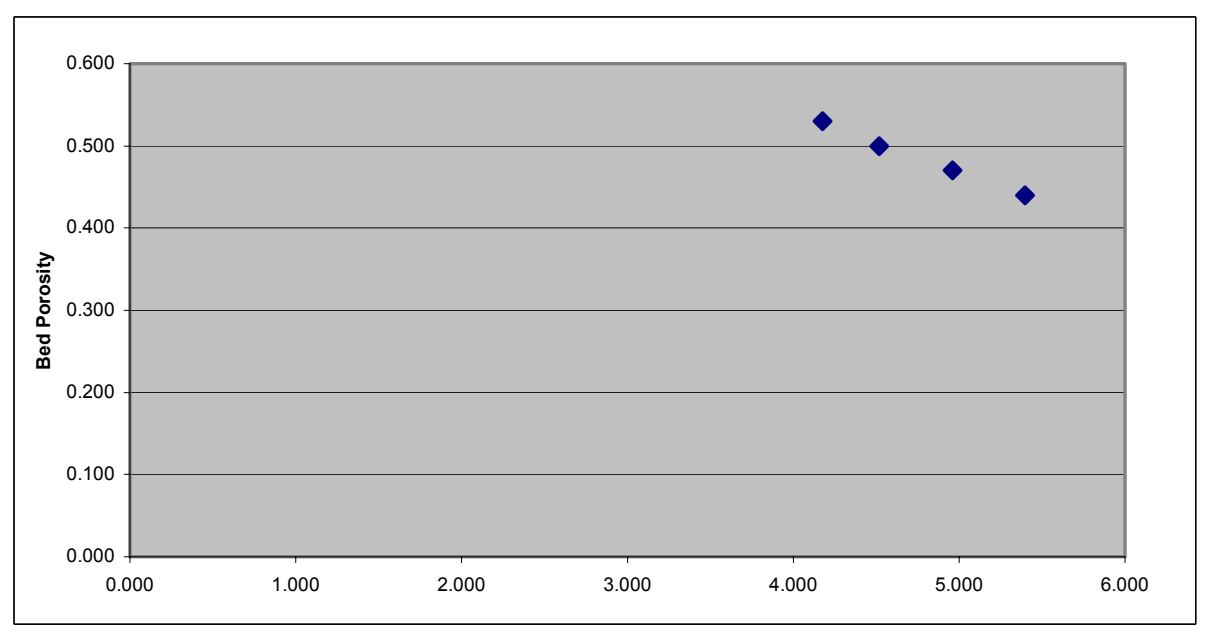




\section{TABLE D.9 TRI-STATE BAGHOUSE FINES SPECIFIC SURFACE AREA}

Source: Tri-State

Type: $\quad$ Baghouse Fines

Tested

Date: $\quad 3 / 20 / 2002$

Constant

\begin{tabular}{|c|c|c|c|}
\hline$S_{s}=$ & 396.6 & $b_{s}=$ & 0.9 \\
\hline$\rho s=$ & 3.15 & $\varepsilon_{\mathrm{s}}=$ & 0.5 \\
\hline $\mathrm{T}_{\mathrm{s}}=$ & 136.16 & Volume Sample $=$ & 1.858 \\
\hline
\end{tabular}

Temperature $=24$ S. G. (oven Dry Sample) $=2.730$

\begin{tabular}{|c|c|c|c|c|}
\hline Porosity & Weight of Sample & $\# 1$ & $\# 2$ & $\# 3$ \\
\hline 0.530 & 2.384 & 122.34 & 129.31 & 129.59 \\
\hline 0.500 & 2.536 & 173.06 & 165.21 & 171.37 \\
\hline 0.470 & 2.689 & 242.53 & 235.34 & 232.78 \\
\hline 0.440 & 2.841 & 343.18 & 355.59 & 353.12 \\
\hline
\end{tabular}

\begin{tabular}{|c|c|c|c|c|}
\hline Porosity & Weight of Sample & $\mathrm{T}$ & $\sqrt{\varepsilon^{3} T}$ & $\mathrm{~S}$ \\
\hline 0.530 & 2.384 & 127.08 & 4.350 & 566.533 \\
\hline 0.500 & 2.536 & 169.88 & 4.609 & 551.730 \\
\hline 0.470 & 2.689 & 236.88 & 4.957 & 548.794 \\
\hline 0.440 & 2.841 & 350.63 & 5.463 & 562.756 \\
Correlation Coefficient $=0.9888 \quad>0.997$
\end{tabular}$\quad \begin{gathered} \\
\text { b }\end{gathered}$

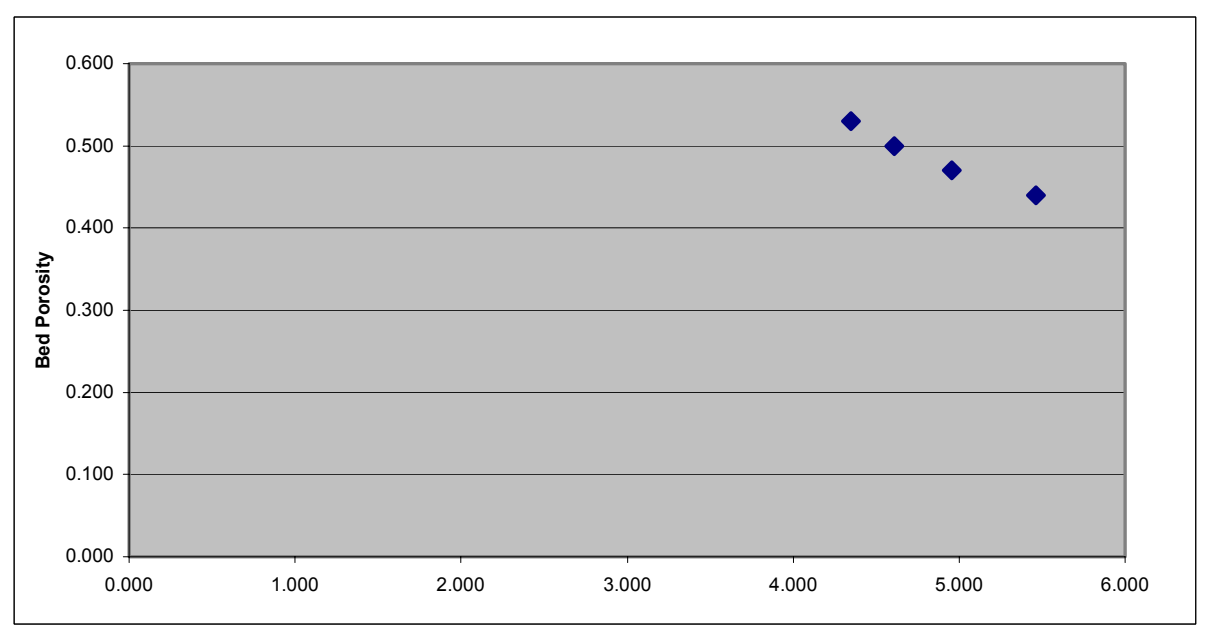




\section{APPENDIX E VOLUMETRIC ANALYSIS RESULTS}

\section{TABLE E.1 VOLUMETRIC ANALYSIS FOR 9.5 mm GRADATION \#1}

\begin{tabular}{|c|c|c|c|c|c|}
\hline $\begin{array}{c}\text { Film } \\
\text { Thickness } 10 \\
\mu \mathrm{m}\end{array}$ & $\begin{array}{c}\text { Edwards- } \\
\text { Hveem }\end{array}$ & Craus-Ishai & $\begin{array}{l}\text { Davg } \\
\text { method }\end{array}$ & $\begin{array}{l}\text { Measured } \\
\text { Sand }\end{array}$ & $\begin{array}{l}\text { Measured } \\
\text { Limestone }\end{array}$ \\
\hline Wbe & 0.052534 & 0.060043 & 0.050215 & 0.082161 & 0.260319 \\
\hline $\mathrm{Wb}$ & 0.065313 & 0.072822 & 0.062994 & 0.094940 & 0.273098 \\
\hline Vba & 0.012528 & 0.012528 & 0.012528 & 0.012528 & 0.012528 \\
\hline Vbe & 0.051504 & 0.058866 & 0.049231 & 0.080550 & 0.255214 \\
\hline $\mathrm{Vb}$ & 0.064032 & 0.071394 & 0.061759 & 0.093079 & 0.267743 \\
\hline Wm & 1.065313 & 1.072822 & 1.062994 & 1.094940 & 1.273098 \\
\hline $\mathrm{Pb}$ & $6.1 \%$ & $6.8 \%$ & $5.9 \%$ & $8.7 \%$ & $21.5 \%$ \\
\hline Pbe & $4.9 \%$ & $5.6 \%$ & $4.7 \%$ & $7.5 \%$ & $20.4 \%$ \\
\hline Vsb & 0.404040 & 0.404040 & 0.404040 & 0.404040 & 0.404040 \\
\hline Vmm & 0.455544 & 0.462906 & 0.453271 & 0.484591 & 0.659255 \\
\hline Vmb & 0.474525 & 0.482194 & 0.472157 & 0.504782 & 0.686724 \\
\hline VMA & $14.9 \%$ & $16.2 \%$ & $14.4 \%$ & $20.0 \%$ & $41.2 \%$ \\
\hline $\mathrm{D} / \mathrm{B}$ & 0.90 & 1.02 & 0.86 & 1.36 & 3.72 \\
\hline VFA & $73 \%$ & $75 \%$ & $72 \%$ & $80 \%$ & $90 \%$ \\
\hline$\%$ Vbe & $11 \%$ & $12 \%$ & $10 \%$ & $16 \%$ & $37 \%$ \\
\hline$\% \mathrm{Vb}$ & $13 \%$ & $15 \%$ & $13 \%$ & $18 \%$ & $39 \%$ \\
\hline
\end{tabular}

\begin{tabular}{|c|c|c|c|c|c|}
\hline $\begin{array}{c}\text { Film } \\
\text { Thickness } 8 \\
\mu \mathrm{m}\end{array}$ & $\begin{array}{c}\text { Edwards- } \\
\text { Hveem }\end{array}$ & Craus-Ishai & $\begin{array}{l}\text { Davg } \\
\text { method }\end{array}$ & $\begin{array}{c}\text { Measured } \\
\text { Sand }\end{array}$ & $\begin{array}{l}\text { Measured } \\
\text { Limestone }\end{array}$ \\
\hline Wbe & 0.042027 & 0.048034 & 0.040172 & 0.065729 & 0.208255 \\
\hline $\mathrm{Wb}$ & 0.054806 & 0.060813 & 0.052951 & 0.078508 & 0.221034 \\
\hline Vba & 0.012528 & 0.012528 & 0.012528 & 0.012528 & 0.012528 \\
\hline Vbe & 0.041203 & 0.047093 & 0.039385 & 0.064440 & 0.204172 \\
\hline $\mathrm{Vb}$ & 0.053731 & 0.059621 & 0.051913 & 0.076969 & 0.216700 \\
\hline Wm & 1.054806 & 1.060813 & 1.052951 & 1.078508 & 1.221034 \\
\hline $\mathrm{Pb}$ & $5.2 \%$ & $5.7 \%$ & $5.0 \%$ & $7.3 \%$ & $18.1 \%$ \\
\hline Pbe & $4.0 \%$ & $4.5 \%$ & $3.8 \%$ & $6.1 \%$ & $17.1 \%$ \\
\hline Vsb & 0.404040 & 0.404040 & 0.404040 & 0.404040 & 0.404040 \\
\hline Vmm & 0.445243 & 0.451133 & 0.443425 & 0.468481 & 0.608212 \\
\hline Vmb & 0.463795 & 0.469930 & 0.461901 & 0.488001 & 0.633554 \\
\hline VMA & $12.9 \%$ & $14.0 \%$ & $12.5 \%$ & $17.2 \%$ & $36.2 \%$ \\
\hline $\mathrm{D} / \mathrm{B}$ & 0.72 & 0.82 & 0.69 & 1.11 & 3.10 \\
\hline VFA & $69 \%$ & $71 \%$ & $68 \%$ & $77 \%$ & $89 \%$ \\
\hline$\%$ Vbe & $9 \%$ & $10 \%$ & $9 \%$ & $13 \%$ & $32 \%$ \\
\hline$\% \mathrm{Vb}$ & $12 \%$ & $13 \%$ & $11 \%$ & $16 \%$ & $34 \%$ \\
\hline
\end{tabular}

\begin{tabular}{c|c|c|c|c|c|}
\cline { 2 - 6 } $\begin{array}{c}\text { Film } \\
\begin{array}{c}\text { Thickness } 6 \\
\mu m\end{array}\end{array}$ & $\begin{array}{c}\text { Edwards- } \\
\text { Hveem }\end{array}$ & Craus-Ishai & $\begin{array}{c}\text { Davg } \\
\text { method }\end{array}$ & $\begin{array}{c}\text { Measured } \\
\text { Sand }\end{array}$ & $\begin{array}{c}\text { Measured } \\
\text { Limestone }\end{array}$ \\
\hline Wbe & 0.031520 & 0.036026 & 0.030129 & 0.049297 & 0.156191 \\
\hline Wb & 0.044299 & 0.048805 & 0.042908 & 0.062076 & 0.168970 \\
\hline $\mathrm{Vba}$ & 0.012528 & 0.012528 & 0.012528 & 0.012528 & 0.012528 \\
\hline $\mathrm{Vbe}$ & 0.030902 & 0.035319 & 0.029538 & 0.048330 & 0.153129 \\
\hline $\mathrm{Vb}$ & 0.043430 & 0.047848 & 0.042067 & 0.060858 & 0.165657 \\
\hline $\mathrm{Wm}$ & 1.044299 & 1.048805 & 1.042908 & 1.062076 & 1.168970 \\
\hline $\mathrm{Pb}$ & $4.2 \%$ & $4.7 \%$ & $4.1 \%$ & $5.8 \%$ & $14.5 \%$ \\
\hline $\mathrm{Pbe}$ & $3.0 \%$ & $3.4 \%$ & $2.9 \%$ & $4.6 \%$ & $13.4 \%$ \\
\hline $\mathrm{Vsb}$ & 0.404040 & 0.404040 & 0.404040 & 0.404040 & 0.404040 \\
\hline $\mathrm{Vmm}$ & 0.434943 & 0.439360 & 0.433579 & 0.452370 & 0.557169 \\
\hline $\mathrm{Vmb}$ & 0.453065 & 0.457666 & 0.451645 & 0.471219 & 0.580384 \\
\hline $\mathrm{VMA}$ & $10.8 \%$ & $11.7 \%$ & $10.5 \%$ & $14.3 \%$ & $30.4 \%$ \\
\hline $\mathrm{D} / \mathrm{B}$ & 0.55 & 0.62 & 0.53 & 0.84 & 2.43 \\
\hline $\mathrm{VFA}$ & $63 \%$ & $66 \%$ & $62 \%$ & $72 \%$ & $87 \%$ \\
\hline$\% \mathrm{Vbe}$ & $7 \%$ & $8 \%$ & $7 \%$ & $10 \%$ & $26 \%$ \\
\hline$\% \mathrm{Vb}$ & $10 \%$ & $10 \%$ & $9 \%$ & $13 \%$ & $29 \%$ \\
\hline
\end{tabular}

\begin{tabular}{c|c|c|c|c|c|}
\cline { 2 - 6 } $\begin{array}{c}\text { Thilm } \\
\mu m\end{array}$ & $\begin{array}{c}\text { Edwards- } \\
\text { Hveem }\end{array}$ & Craus-Ishai & $\begin{array}{c}\text { Davg } \\
\text { method }\end{array}$ & $\begin{array}{c}\text { Measured } \\
\text { Sand }\end{array}$ & $\begin{array}{c}\text { Measured } \\
\text { Limestone }\end{array}$ \\
\hline Wbe & 0.021013 & 0.024017 & 0.020086 & 0.032864 & 0.104127 \\
\hline $\mathrm{Wb}$ & 0.033792 & 0.036796 & 0.032865 & 0.045643 & 0.116906 \\
\hline $\mathrm{Vba}$ & 0.012528 & 0.012528 & 0.012528 & 0.012528 & 0.012528 \\
\hline $\mathrm{Vbe}$ & 0.020601 & 0.023546 & 0.019692 & 0.032220 & 0.102086 \\
\hline $\mathrm{Vb}$ & 0.033130 & 0.036075 & 0.032221 & 0.044748 & 0.114614 \\
\hline $\mathrm{Wm}$ & 1.033792 & 1.036796 & 1.032865 & 1.045643 & 1.116906 \\
\hline $\mathrm{Pb}$ & $3.3 \%$ & $3.5 \%$ & $3.2 \%$ & $4.4 \%$ & $10.5 \%$ \\
\hline $\mathrm{Pbe}$ & $2.0 \%$ & $2.3 \%$ & $1.9 \%$ & $3.1 \%$ & $9.3 \%$ \\
\hline $\mathrm{Vsb}$ & 0.404040 & 0.404040 & 0.404040 & 0.404040 & 0.404040 \\
\hline $\mathrm{Vmm}$ & 0.424642 & 0.427587 & 0.423733 & 0.436260 & 0.506126 \\
\hline $\mathrm{Vmb}$ & 0.442335 & 0.445403 & 0.441388 & 0.454438 & 0.527215 \\
\hline $\mathrm{VMA}$ & $8.7 \%$ & $9.3 \%$ & $8.5 \%$ & $11.1 \%$ & $23.4 \%$ \\
\hline $\mathrm{D} / \mathrm{B}$ & 0.37 & 0.42 & 0.35 & 0.57 & 1.70 \\
\hline $\mathrm{VFA}$ & $54 \%$ & $57 \%$ & $53 \%$ & $64 \%$ & $83 \%$ \\
\hline$\% \mathrm{Vbe}$ & $5 \%$ & $5 \%$ & $4 \%$ & $7 \%$ & $19 \%$ \\
\hline$\% \mathrm{Vb}$ & $7 \%$ & $8 \%$ & $7 \%$ & $10 \%$ & $22 \%$ \\
\hline
\end{tabular}

\begin{tabular}{c|c|c|c|c|c|}
\cline { 2 - 6 } $\begin{array}{c}\text { Film } \\
\begin{array}{c}\text { Thickness 2 } \\
\mu m\end{array}\end{array}$ & $\begin{array}{c}\text { Edwards- } \\
\text { Hveem }\end{array}$ & Craus-Ishai & $\begin{array}{c}\text { Davg } \\
\text { method }\end{array}$ & $\begin{array}{c}\text { Measured } \\
\text { Sand }\end{array}$ & $\begin{array}{c}\text { Measured } \\
\text { Limestone }\end{array}$ \\
\hline Wbe & 0.010507 & 0.012009 & 0.010043 & 0.016432 & 0.052064 \\
\hline $\mathrm{Wb}$ & 0.023286 & 0.024788 & 0.022822 & 0.029211 & 0.064843 \\
\hline $\mathrm{Vba}$ & 0.012528 & 0.012528 & 0.012528 & 0.012528 & 0.012528 \\
\hline $\mathrm{Vbe}$ & 0.010301 & 0.011773 & 0.009846 & 0.016110 & 0.051043 \\
\hline $\mathrm{Vb}$ & 0.022829 & 0.024302 & 0.022375 & 0.028638 & 0.063571 \\
\hline $\mathrm{Wm}$ & 1.023286 & 1.024788 & 1.022822 & 1.029211 & 1.064843 \\
\hline $\mathrm{Pb}$ & $2.3 \%$ & $2.4 \%$ & $2.2 \%$ & $2.8 \%$ & $6.1 \%$ \\
\hline $\mathrm{Pbe}$ & $1.0 \%$ & $1.2 \%$ & $1.0 \%$ & $1.6 \%$ & $4.9 \%$ \\
\hline $\mathrm{Vsb}$ & 0.404040 & 0.404040 & 0.404040 & 0.404040 & 0.404040 \\
\hline $\mathrm{Vmm}$ & 0.414341 & 0.415814 & 0.413887 & 0.420150 & 0.455083 \\
\hline $\mathrm{Vmb}$ & 0.431605 & 0.433139 & 0.431132 & 0.437657 & 0.474045 \\
\hline $\mathrm{VMA}$ & $6.4 \%$ & $6.7 \%$ & $6.3 \%$ & $7.7 \%$ & $14.8 \%$ \\
\hline $\mathrm{D} / \mathrm{B}$ & 0.19 & 0.21 & 0.18 & 0.29 & 0.89 \\
\hline $\mathrm{VFA}$ & $37 \%$ & $40 \%$ & $36 \%$ & $48 \%$ & $73 \%$ \\
\hline$\% \mathrm{Vbe}$ & $2 \%$ & $3 \%$ & $2 \%$ & $4 \%$ & $11 \%$ \\
\hline$\% \mathrm{Vb}$ & $5 \%$ & $6 \%$ & $5 \%$ & $7 \%$ & $13 \%$ \\
\hline & & & & & \\
\hline
\end{tabular}


TABLE E.2 VOLUMETRIC ANALYSIS FOR 9.5 mm GRADATION \#2

\begin{tabular}{|c|c|c|c|c|c|}
\hline $\begin{array}{c}\text { Film } \\
\text { Thickness } 10 \\
\mu \mathrm{m}\end{array}$ & $\begin{array}{l}\text { Edwards- } \\
\text { Hveem }\end{array}$ & Craus-Ishai & $\begin{array}{l}\text { Davg } \\
\text { method }\end{array}$ & $\begin{array}{c}\text { Measured } \\
\text { Sand }\end{array}$ & $\begin{array}{l}\text { Measured } \\
\text { Limestone }\end{array}$ \\
\hline Wbe & 0.049902 & 0.057071 & 0.047235 & 0.073987 & 0.238480 \\
\hline $\mathrm{Wb}$ & 0.062081 & 0.069250 & 0.059414 & 0.086165 & 0.250658 \\
\hline Vba & 0.011940 & 0.011940 & 0.011940 & 0.011940 & 0.011940 \\
\hline Vbe & 0.048924 & 0.055952 & 0.046309 & 0.072536 & 0.233803 \\
\hline $\mathrm{Vb}$ & 0.060864 & 0.067892 & 0.058249 & 0.084476 & 0.245743 \\
\hline $\mathrm{Wm}$ & 1.062081 & 1.069250 & 1.059414 & 1.086165 & 1.250658 \\
\hline $\mathrm{Pb}$ & $5.8 \%$ & $6.5 \%$ & $5.6 \%$ & $7.9 \%$ & $20.0 \%$ \\
\hline Pbe & $4.7 \%$ & $5.3 \%$ & $4.5 \%$ & $6.8 \%$ & $19.1 \%$ \\
\hline Vsb & 0.385060 & 0.385060 & 0.385060 & 0.385060 & 0.385060 \\
\hline Vmm & 0.433983 & 0.441012 & 0.431369 & 0.457596 & 0.618863 \\
\hline $\mathrm{Vmb}$ & 0.452066 & 0.459387 & 0.449343 & 0.476662 & 0.644649 \\
\hline VMA & $14.8 \%$ & $16.2 \%$ & $14.3 \%$ & $19.2 \%$ & $40.3 \%$ \\
\hline $\mathrm{D} / \mathrm{B}$ & 0.94 & 1.07 & 0.89 & 1.36 & 3.81 \\
\hline VFA & $73 \%$ & $75 \%$ & $72 \%$ & $79 \%$ & $90 \%$ \\
\hline$\%$ Vbe & $11 \%$ & $12 \%$ & $10 \%$ & $15 \%$ & $36 \%$ \\
\hline$\% \mathrm{Vb}$ & $13 \%$ & $15 \%$ & $13 \%$ & $18 \%$ & $38 \%$ \\
\hline $\begin{array}{c}\text { Film } \\
\text { Thickness } 6 \\
\mu \mathrm{m}\end{array}$ & $\begin{array}{l}\text { Edwards- } \\
\text { Hveem }\end{array}$ & Craus-Ishai & $\begin{array}{l}\text { Davg } \\
\text { method }\end{array}$ & $\begin{array}{l}\text { Measured } \\
\text { Sand }\end{array}$ & $\begin{array}{l}\text { Measured } \\
\text { Limestone }\end{array}$ \\
\hline Wbe & 0.029941 & 0.034243 & 0.028341 & 0.044392 & 0.143088 \\
\hline $\mathrm{Wb}$ & 0.042120 & 0.046421 & 0.040520 & 0.056571 & 0.155266 \\
\hline Vba & 0.011940 & 0.011940 & 0.011940 & 0.011940 & 0.011940 \\
\hline Vbe & 0.029354 & 0.033571 & 0.027786 & 0.043521 & 0.140282 \\
\hline $\mathrm{Vb}$ & 0.041294 & 0.045511 & 0.039725 & 0.055461 & 0.152222 \\
\hline Wm & 1.042120 & 1.046421 & 1.040520 & 1.056571 & 1.155266 \\
\hline $\mathrm{Pb}$ & $4.0 \%$ & $4.4 \%$ & $3.9 \%$ & $5.4 \%$ & $13.4 \%$ \\
\hline Pbe & $2.9 \%$ & $3.3 \%$ & $2.7 \%$ & $4.2 \%$ & $12.4 \%$ \\
\hline Vsb & 0.385060 & 0.385060 & 0.385060 & 0.385060 & 0.385060 \\
\hline Vmm & 0.414414 & 0.418631 & 0.412845 & 0.428581 & 0.525342 \\
\hline Vmb & 0.431681 & 0.436074 & 0.430047 & 0.446439 & 0.547231 \\
\hline VMA & $10.8 \%$ & $11.7 \%$ & $10.5 \%$ & $13.7 \%$ & $29.6 \%$ \\
\hline $\mathrm{D} / \mathrm{B}$ & 0.57 & 0.65 & 0.54 & 0.84 & 2.48 \\
\hline VFA & $63 \%$ & $66 \%$ & $62 \%$ & $71 \%$ & $87 \%$ \\
\hline$\%$ Vbe & $7 \%$ & $8 \%$ & $6 \%$ & $10 \%$ & $26 \%$ \\
\hline$\% \mathrm{Vb}$ & $10 \%$ & $10 \%$ & $9 \%$ & $12 \%$ & $28 \%$ \\
\hline
\end{tabular}

\begin{tabular}{|c|c|c|c|c|c|}
\hline $\begin{array}{c}\text { Film } \\
\text { Thickness } 8 \\
\mu \mathrm{m}\end{array}$ & $\begin{array}{c}\text { Edwards- } \\
\text { Hveem }\end{array}$ & Craus-Ishai & $\begin{array}{l}\text { Davg } \\
\text { method }\end{array}$ & $\begin{array}{l}\text { Measured } \\
\text { Sand }\end{array}$ & $\begin{array}{l}\text { Measured } \\
\text { Limestone }\end{array}$ \\
\hline Wbe & 0.039922 & 0.045657 & 0.037788 & 0.059189 & 0.190784 \\
\hline $\mathrm{Wb}$ & 0.052100 & 0.057836 & 0.049967 & 0.071368 & 0.202962 \\
\hline Vba & 0.011940 & 0.011940 & 0.011940 & 0.011940 & 0.011940 \\
\hline Vbe & 0.039139 & 0.044762 & 0.037047 & 0.058029 & 0.187043 \\
\hline $\mathrm{Vb}$ & 0.051079 & 0.056702 & 0.048987 & 0.069968 & 0.198983 \\
\hline Wm & 1.052100 & 1.057836 & 1.049967 & 1.071368 & 1.202962 \\
\hline $\mathrm{Pb}$ & $5.0 \%$ & $5.5 \%$ & $4.8 \%$ & $6.7 \%$ & $16.9 \%$ \\
\hline Pbe & $3.8 \%$ & $4.3 \%$ & $3.6 \%$ & $5.5 \%$ & $15.9 \%$ \\
\hline Vsb & 0.385060 & 0.385060 & 0.385060 & 0.385060 & 0.385060 \\
\hline Vmm & 0.424199 & 0.429821 & 0.422107 & 0.443088 & 0.572102 \\
\hline Vmb & 0.441874 & 0.447731 & 0.439695 & 0.461550 & 0.595940 \\
\hline VMA & $12.9 \%$ & $14.0 \%$ & $12.4 \%$ & $16.6 \%$ & $35.4 \%$ \\
\hline D/B & 0.76 & 0.86 & 0.72 & 1.10 & 3.17 \\
\hline VFA & $69 \%$ & $71 \%$ & $68 \%$ & $76 \%$ & $89 \%$ \\
\hline$\%$ Vbe & $9 \%$ & $10 \%$ & $8 \%$ & $13 \%$ & $31 \%$ \\
\hline$\% \mathrm{Vb}$ & $12 \%$ & $13 \%$ & $11 \%$ & $15 \%$ & $33 \%$ \\
\hline
\end{tabular}

\begin{tabular}{|c|c|c|c|c|c|}
\cline { 2 - 6 } $\begin{array}{c}\text { Film } \\
\begin{array}{c}\text { Thickness 4 } \\
\mu \mathrm{m}\end{array}\end{array}$ & $\begin{array}{c}\text { Edwards- } \\
\text { Hveem }\end{array}$ & Craus-Ishai & $\begin{array}{c}\text { Davg } \\
\text { method }\end{array}$ & $\begin{array}{c}\text { Measured } \\
\text { Sand }\end{array}$ & $\begin{array}{c}\text { Measured } \\
\text { Limestone }\end{array}$ \\
\hline Wbe & 0.019961 & 0.022828 & 0.018894 & 0.029595 & 0.095392 \\
\hline Wb & 0.032140 & 0.035007 & 0.031073 & 0.041773 & 0.107570 \\
\hline Vba & 0.011940 & 0.011940 & 0.011940 & 0.011940 & 0.011940 \\
\hline Vbe & 0.019570 & 0.022381 & 0.018524 & 0.029014 & 0.093521 \\
\hline Vb & 0.031509 & 0.034321 & 0.030464 & 0.040954 & 0.105461 \\
\hline Wm & 1.032140 & 1.035007 & 1.031073 & 1.041773 & 1.107570 \\
\hline $\mathrm{Pb}$ & $3.1 \%$ & $3.4 \%$ & $3.0 \%$ & $4.0 \%$ & $9.7 \%$ \\
\hline $\mathrm{Pbe}$ & $1.9 \%$ & $2.2 \%$ & $1.8 \%$ & $2.8 \%$ & $8.6 \%$ \\
\hline Vsb & 0.385060 & 0.385060 & 0.385060 & 0.385060 & 0.385060 \\
\hline Vmm & 0.404629 & 0.407441 & 0.403583 & 0.414074 & 0.478581 \\
\hline Vmb & 0.421489 & 0.424417 & 0.420399 & 0.431327 & 0.498522 \\
\hline VMA & $8.6 \%$ & $9.3 \%$ & $8.4 \%$ & $10.7 \%$ & $22.8 \%$ \\
\hline $\mathrm{D} / \mathrm{B}$ & 0.39 & 0.44 & 0.37 & 0.57 & 1.72 \\
\hline $\mathrm{VFA}$ & $54 \%$ & $57 \%$ & $52 \%$ & $63 \%$ & $82 \%$ \\
\hline$\% \mathrm{Vbe}$ & $5 \%$ & $5 \%$ & $4 \%$ & $7 \%$ & $19 \%$ \\
\hline$\%$ Vb & $7 \%$ & $8 \%$ & $7 \%$ & $9 \%$ & $21 \%$ \\
\hline & & & & & \\
\hline
\end{tabular}

\begin{tabular}{|c|c|c|c|c|c|}
\hline $\begin{array}{c}\text { Film } \\
\text { Thickness } 2 \\
\mu \mathrm{m}\end{array}$ & $\begin{array}{c}\text { Edwards- } \\
\text { Hveem }\end{array}$ & Craus-Ishai & $\begin{array}{l}\text { Davg } \\
\text { method }\end{array}$ & $\begin{array}{l}\text { Measured } \\
\text { Sand }\end{array}$ & $\begin{array}{l}\text { Measured } \\
\text { Limestone }\end{array}$ \\
\hline Wbe & 0.009980 & 0.011414 & 0.009447 & 0.014797 & 0.047696 \\
\hline $\mathrm{Wb}$ & 0.022159 & 0.023593 & 0.021626 & 0.026976 & 0.059875 \\
\hline Vba & 0.011940 & 0.011940 & 0.011940 & 0.011940 & 0.011940 \\
\hline Vbe & 0.009785 & 0.011190 & 0.009262 & 0.014507 & 0.046761 \\
\hline $\mathrm{Vb}$ & 0.021725 & 0.023130 & 0.021202 & 0.026447 & 0.058701 \\
\hline $\mathrm{Wm}$ & 1.022159 & 1.023593 & 1.021626 & 1.026976 & 1.059875 \\
\hline $\mathrm{Pb}$ & $2.2 \%$ & $2.3 \%$ & $2.1 \%$ & $2.6 \%$ & $5.6 \%$ \\
\hline Pbe & $1.0 \%$ & $1.1 \%$ & $0.9 \%$ & $1.4 \%$ & $4.5 \%$ \\
\hline Vsb & 0.385060 & 0.385060 & 0.385060 & 0.385060 & 0.385060 \\
\hline Vmm & 0.394844 & 0.396250 & 0.394322 & 0.399567 & 0.431820 \\
\hline Vmb & 0.411296 & 0.412761 & 0.410752 & 0.416215 & 0.449813 \\
\hline VMA & $6.4 \%$ & $6.7 \%$ & $6.3 \%$ & $7.5 \%$ & $14.4 \%$ \\
\hline$D / B$ & 0.20 & 0.22 & 0.18 & 0.29 & 0.90 \\
\hline VFA & $37 \%$ & $40 \%$ & $36 \%$ & $47 \%$ & $72 \%$ \\
\hline$\%$ Vbe & $2 \%$ & $3 \%$ & $2 \%$ & $3 \%$ & $10 \%$ \\
\hline$\% \mathrm{Vb}$ & $5 \%$ & $6 \%$ & $5 \%$ & $6 \%$ & $13 \%$ \\
\hline
\end{tabular}


TABLE E.3 VOLUMETRIC ANALYSIS FOR 9.5 mm GRADATION \#3

\begin{tabular}{|c|c|c|c|c|c|}
\hline $\begin{array}{c}\text { Film } \\
\text { Thickness } 10 \\
\mu \mathrm{m}\end{array}$ & $\begin{array}{l}\text { Edwards- } \\
\text { Hveem }\end{array}$ & Craus-Ishai & $\begin{array}{l}\text { Davg } \\
\text { method }\end{array}$ & $\begin{array}{l}\text { Measured } \\
\text { Sand }\end{array}$ & $\begin{array}{l}\text { Measured } \\
\text { Limestone }\end{array}$ \\
\hline Wbe & 0.045472 & 0.052551 & 0.042571 & 0.065105 & 0.203210 \\
\hline $\mathrm{Wb}$ & 0.057376 & 0.064454 & 0.054475 & 0.077009 & 0.215113 \\
\hline Vba & 0.011670 & 0.011670 & 0.011670 & 0.011670 & 0.011670 \\
\hline Vbe & 0.044580 & 0.051520 & 0.041736 & 0.063829 & 0.199225 \\
\hline $\mathrm{Vb}$ & 0.056251 & 0.063191 & 0.053407 & 0.075499 & 0.210895 \\
\hline Wm & 1.057376 & 1.064454 & 1.054475 & 1.077009 & 1.215113 \\
\hline $\mathrm{Pb}$ & $5.4 \%$ & $6.1 \%$ & $5.2 \%$ & $7.2 \%$ & $17.7 \%$ \\
\hline Pbe & $4.3 \%$ & $4.9 \%$ & $4.0 \%$ & $6.0 \%$ & $16.7 \%$ \\
\hline Vsb & 0.376364 & 0.376364 & 0.376364 & 0.376364 & 0.376364 \\
\hline Vmm & 0.420945 & 0.427885 & 0.418101 & 0.440193 & 0.575589 \\
\hline Vmb & 0.438484 & 0.445713 & 0.435522 & 0.458534 & 0.599572 \\
\hline VMA & $14.2 \%$ & $15.6 \%$ & $13.6 \%$ & $17.9 \%$ & $37.2 \%$ \\
\hline $\mathrm{D} / \mathrm{B}$ & 1.02 & 1.18 & 0.96 & 1.44 & 3.98 \\
\hline VFA & $72 \%$ & $74 \%$ & $71 \%$ & $78 \%$ & $89 \%$ \\
\hline$\%$ Vbe & $10 \%$ & $12 \%$ & $10 \%$ & $14 \%$ & $33 \%$ \\
\hline$\% \mathrm{Vb}$ & $13 \%$ & $14 \%$ & $12 \%$ & $16 \%$ & $35 \%$ \\
\hline
\end{tabular}

\begin{tabular}{c|c|c|c|c|c|}
\cline { 2 - 6 } $\begin{array}{c}\text { Film } \\
\begin{array}{c}\text { Thickness 8 } \\
\mu \mathrm{m}\end{array}\end{array}$ & $\begin{array}{c}\text { Edwards- } \\
\text { Hveem }\end{array}$ & Craus-Ishai & $\begin{array}{c}\text { Davg } \\
\text { method }\end{array}$ & $\begin{array}{c}\text { Measured } \\
\text { Sand }\end{array}$ & $\begin{array}{c}\text { Measured } \\
\text { Limestone }\end{array}$ \\
\hline Wbe & 0.036378 & 0.042041 & 0.034057 & 0.052084 & 0.162568 \\
\hline $\mathrm{Wb}$ & 0.048281 & 0.053944 & 0.045961 & 0.063988 & 0.174471 \\
\hline $\mathrm{Vba}$ & 0.011670 & 0.011670 & 0.011670 & 0.011670 & 0.011670 \\
\hline $\mathrm{Vbe}$ & 0.035664 & 0.041216 & 0.033389 & 0.051063 & 0.159380 \\
\hline $\mathrm{Vb}$ & 0.047335 & 0.052887 & 0.045059 & 0.062733 & 0.171050 \\
\hline $\mathrm{Wm}$ & 1.048281 & 1.053944 & 1.045961 & 1.063988 & 1.174471 \\
\hline $\mathrm{Pb}$ & $4.6 \%$ & $5.1 \%$ & $4.4 \%$ & $6.0 \%$ & $14.9 \%$ \\
\hline $\mathrm{Pbe}$ & $3.5 \%$ & $4.0 \%$ & $3.3 \%$ & $4.9 \%$ & $13.8 \%$ \\
\hline $\mathrm{Vsb}$ & 0.376364 & 0.376364 & 0.376364 & 0.376364 & 0.376364 \\
\hline $\mathrm{Vmm}$ & 0.412029 & 0.417581 & 0.409753 & 0.427427 & 0.535744 \\
\hline $\mathrm{Vmb}$ & 0.429197 & 0.434980 & 0.426827 & 0.445237 & 0.558067 \\
\hline $\mathrm{VMA}$ & $12.3 \%$ & $13.5 \%$ & $11.8 \%$ & $15.5 \%$ & $32.6 \%$ \\
\hline $\mathrm{D} / \mathrm{B}$ & 0.83 & 0.95 & 0.78 & 1.17 & 3.30 \\
\hline $\mathrm{VFA}$ & $68 \%$ & $70 \%$ & $66 \%$ & $74 \%$ & $88 \%$ \\
\hline$\% \mathrm{Vbe}$ & $8 \%$ & $9 \%$ & $8 \%$ & $11 \%$ & $29 \%$ \\
\hline$\% \mathrm{Vb}$ & $11 \%$ & $12 \%$ & $11 \%$ & $14 \%$ & $31 \%$ \\
\hline
\end{tabular}

\begin{tabular}{|c|c|c|c|c|c|}
\hline $\begin{array}{c}\text { Film } \\
\text { Thickness } 6 \\
\mu \mathrm{m}\end{array}$ & $\begin{array}{c}\text { Edwards- } \\
\text { Hveem }\end{array}$ & Craus-Ishai & $\begin{array}{l}\text { Davg } \\
\text { method }\end{array}$ & $\begin{array}{l}\text { Measured } \\
\text { Sand }\end{array}$ & $\begin{array}{l}\text { Measured } \\
\text { Limestone }\end{array}$ \\
\hline Wbe & 0.027283 & 0.031531 & 0.025543 & 0.039063 & 0.121926 \\
\hline $\mathrm{Wb}$ & 0.039187 & 0.043434 & 0.037446 & 0.050967 & 0.133829 \\
\hline Vba & 0.011670 & 0.011670 & 0.011670 & 0.011670 & 0.011670 \\
\hline Vbe & 0.026748 & 0.030912 & 0.025042 & 0.038297 & 0.119535 \\
\hline $\mathrm{Vb}$ & 0.038418 & 0.042582 & 0.036712 & 0.049967 & 0.131205 \\
\hline Wm & 1.039187 & 1.043434 & 1.037446 & 1.050967 & 1.133829 \\
\hline $\mathrm{Pb}$ & $3.8 \%$ & $4.2 \%$ & $3.6 \%$ & $4.8 \%$ & $11.8 \%$ \\
\hline Pbe & $2.6 \%$ & $3.0 \%$ & $2.5 \%$ & $3.7 \%$ & $10.8 \%$ \\
\hline Vsb & 0.376364 & 0.376364 & 0.376364 & 0.376364 & 0.376364 \\
\hline Vmm & 0.403113 & 0.407277 & 0.401406 & 0.414661 & 0.495899 \\
\hline Vmb & 0.419909 & 0.424246 & 0.418131 & 0.431939 & 0.516562 \\
\hline VMA & $10.4 \%$ & $11.3 \%$ & $10.0 \%$ & $12.9 \%$ & $27.1 \%$ \\
\hline $\mathrm{D} / \mathrm{B}$ & 0.63 & 0.72 & 0.59 & 0.88 & 2.56 \\
\hline VFA & $61 \%$ & $65 \%$ & $60 \%$ & $69 \%$ & $85 \%$ \\
\hline$\%$ Vbe & $6 \%$ & $7 \%$ & $6 \%$ & $9 \%$ & $23 \%$ \\
\hline$\% \mathrm{Vb}$ & $9 \%$ & $10 \%$ & $9 \%$ & $12 \%$ & $25 \%$ \\
\hline
\end{tabular}

\begin{tabular}{|c|c|c|c|c|c|}
\hline $\begin{array}{c}\text { Film } \\
\text { Thickness } 4 \\
\mu \mathrm{m}\end{array}$ & $\begin{array}{c}\text { Edwards- } \\
\text { Hveem }\end{array}$ & Craus-Ishai & $\begin{array}{l}\text { Davg } \\
\text { method }\end{array}$ & $\begin{array}{l}\text { Measured } \\
\text { Sand }\end{array}$ & $\begin{array}{l}\text { Measured } \\
\text { Limestone }\end{array}$ \\
\hline Wbe & 0.018189 & 0.021020 & 0.017028 & 0.026042 & 0.081284 \\
\hline $\mathrm{Wb}$ & 0.030092 & 0.032924 & 0.028932 & 0.037946 & 0.093187 \\
\hline Vba & 0.011670 & 0.011670 & 0.011670 & 0.011670 & 0.011670 \\
\hline Vbe & 0.017832 & 0.020608 & 0.016695 & 0.025531 & 0.079690 \\
\hline $\mathrm{Vb}$ & 0.029502 & 0.032278 & 0.028365 & 0.037202 & 0.091360 \\
\hline Wm & 1.030092 & 1.032924 & 1.028932 & 1.037946 & 1.093187 \\
\hline $\mathrm{Pb}$ & $2.9 \%$ & $3.2 \%$ & $2.8 \%$ & $3.7 \%$ & $8.5 \%$ \\
\hline Pbe & $1.8 \%$ & $2.0 \%$ & $1.7 \%$ & $2.5 \%$ & $7.4 \%$ \\
\hline Vsb & 0.376364 & 0.376364 & 0.376364 & 0.376364 & 0.376364 \\
\hline Vmm & 0.394196 & 0.396972 & 0.393059 & 0.401896 & 0.456054 \\
\hline Vmb & 0.410621 & 0.413513 & 0.409436 & 0.418641 & 0.475057 \\
\hline VMA & $8.3 \%$ & $9.0 \%$ & $8.1 \%$ & $10.1 \%$ & $20.8 \%$ \\
\hline $\mathrm{D} / \mathrm{B}$ & 0.42 & 0.48 & 0.39 & 0.60 & 1.77 \\
\hline VFA & $52 \%$ & $55 \%$ & $50 \%$ & $60 \%$ & $81 \%$ \\
\hline$\%$ Vbe & $4 \%$ & $5 \%$ & $4 \%$ & $6 \%$ & $17 \%$ \\
\hline$\% \mathrm{Vb}$ & $7 \%$ & $8 \%$ & $7 \%$ & $9 \%$ & $19 \%$ \\
\hline
\end{tabular}

\begin{tabular}{|c|c|c|c|c|c|}
\hline $\begin{array}{c}\text { Film } \\
\text { Thickness } 2 \\
\mu \mathrm{m}\end{array}$ & $\begin{array}{c}\text { Edwards- } \\
\text { Hveem }\end{array}$ & Craus-Ishai & $\begin{array}{l}\text { Davg } \\
\text { method }\end{array}$ & $\begin{array}{l}\text { Measured } \\
\text { Sand }\end{array}$ & $\begin{array}{l}\text { Measured } \\
\text { Limestone }\end{array}$ \\
\hline Wbe & 0.009094 & 0.010510 & 0.008514 & 0.013021 & 0.040642 \\
\hline $\mathrm{Wb}$ & 0.020998 & 0.022414 & 0.020418 & 0.024925 & 0.052546 \\
\hline Vba & 0.011670 & 0.011670 & 0.011670 & 0.011670 & 0.011670 \\
\hline Vbe & 0.008916 & 0.010304 & 0.008347 & 0.012766 & 0.039845 \\
\hline $\mathrm{Vb}$ & 0.020586 & 0.021974 & 0.020017 & 0.024436 & 0.051515 \\
\hline Wm & 1.020998 & 1.022414 & 1.020418 & 1.024925 & 1.052546 \\
\hline $\mathrm{Pb}$ & $2.1 \%$ & $2.2 \%$ & $2.0 \%$ & $2.4 \%$ & $5.0 \%$ \\
\hline Pbe & $0.9 \%$ & $1.0 \%$ & $0.8 \%$ & $1.3 \%$ & $3.9 \%$ \\
\hline Vsb & 0.376364 & 0.376364 & 0.376364 & 0.376364 & 0.376364 \\
\hline Vmm & 0.385280 & 0.386668 & 0.384712 & 0.389130 & 0.416209 \\
\hline Vmb & 0.401334 & 0.402780 & 0.400741 & 0.405344 & 0.433551 \\
\hline VMA & $6.2 \%$ & $6.6 \%$ & $6.1 \%$ & $7.1 \%$ & $13.2 \%$ \\
\hline $\mathrm{D} / \mathrm{B}$ & 0.21 & 0.24 & 0.20 & 0.30 & 0.92 \\
\hline VFA & $36 \%$ & $39 \%$ & $34 \%$ & $44 \%$ & $70 \%$ \\
\hline$\%$ Vbe & $2 \%$ & $3 \%$ & $2 \%$ & $3 \%$ & $9 \%$ \\
\hline$\% \mathrm{Vb}$ & $5 \%$ & $5 \%$ & $5 \%$ & $6 \%$ & $12 \%$ \\
\hline
\end{tabular}


TABLE E.4 VOLUMETRIC ANALYSIS FOR 9.5 mm GRADATION \#4

\begin{tabular}{c|c|c|c|c|c|}
\cline { 2 - 6 } $\begin{array}{c}\text { Film } \\
\begin{array}{c}\text { Thickness } 10 \\
\mu m\end{array}\end{array}$ & $\begin{array}{c}\text { Edwards- } \\
\text { Hveem }\end{array}$ & Craus-Ishai & $\begin{array}{c}\text { Davg } \\
\text { method }\end{array}$ & $\begin{array}{c}\text { Measured } \\
\text { Sand }\end{array}$ & $\begin{array}{c}\text { Measured } \\
\text { Limestone }\end{array}$ \\
\hline Wbe & 0.051280 & 0.058757 & 0.048551 & 0.076551 & 0.243545 \\
\hline Wb & 0.063492 & 0.070969 & 0.060763 & 0.088763 & 0.255757 \\
\hline Vba & 0.011972 & 0.011972 & 0.011972 & 0.011972 & 0.011972 \\
\hline Vbe & 0.050275 & 0.057605 & 0.047599 & 0.075050 & 0.238770 \\
\hline Vb & 0.062247 & 0.069577 & 0.059571 & 0.087022 & 0.250742 \\
\hline Wm & 1.063492 & 1.070969 & 1.060763 & 1.088763 & 1.255757 \\
\hline Pb & $6.0 \%$ & $6.6 \%$ & $5.7 \%$ & $8.2 \%$ & $20.4 \%$ \\
\hline Pbe & $4.8 \%$ & $5.5 \%$ & $4.6 \%$ & $7.0 \%$ & $19.4 \%$ \\
\hline Vsb & 0.386100 & 0.386100 & 0.386100 & 0.386100 & 0.386100 \\
\hline Vmm & 0.436375 & 0.443705 & 0.433700 & 0.461151 & 0.624870 \\
\hline Vmb & 0.454558 & 0.462193 & 0.451771 & 0.480365 & 0.650906 \\
\hline VMA & $15.1 \%$ & $16.5 \%$ & $14.5 \%$ & $19.6 \%$ & $40.7 \%$ \\
\hline $\mathrm{D} / \mathrm{B}$ & 0.95 & 1.08 & 0.90 & 1.38 & 3.80 \\
\hline VFA & $73 \%$ & $76 \%$ & $72 \%$ & $80 \%$ & $90 \%$ \\
\hline$\%$ Vbe & $11 \%$ & $12 \%$ & $11 \%$ & $16 \%$ & $37 \%$ \\
\hline$\%$ Vb & $14 \%$ & $15 \%$ & $13 \%$ & $18 \%$ & $39 \%$ \\
\hline & & & & & \\
\hline
\end{tabular}

\begin{tabular}{c|c|c|c|c|c|}
\cline { 2 - 6 } $\begin{array}{c}\text { Film } \\
\begin{array}{c}\text { Thickness 8 } \\
\mu \mathrm{mm}\end{array}\end{array}$ & $\begin{array}{c}\text { Edwards- } \\
\text { Hveem }\end{array}$ & Craus-Ishai & $\begin{array}{c}\text { Davg } \\
\text { method }\end{array}$ & $\begin{array}{c}\text { Measured } \\
\text { Sand }\end{array}$ & $\begin{array}{c}\text { Measured } \\
\text { Limestone }\end{array}$ \\
\hline Wbe & 0.041024 & 0.047006 & 0.038841 & 0.061241 & 0.194836 \\
\hline Wb & 0.053236 & 0.059217 & 0.051053 & 0.073453 & 0.207048 \\
\hline Vba & 0.011972 & 0.011972 & 0.011972 & 0.011972 & 0.011972 \\
\hline Vbe & 0.040220 & 0.046084 & 0.038079 & 0.060040 & 0.191016 \\
\hline Vb & 0.052192 & 0.058056 & 0.050052 & 0.072012 & 0.202988 \\
\hline Wm & 1.053236 & 1.059217 & 1.051053 & 1.073453 & 1.207048 \\
\hline Pb & $5.1 \%$ & $5.6 \%$ & $4.9 \%$ & $6.8 \%$ & $17.2 \%$ \\
\hline Pbe & $3.9 \%$ & $4.4 \%$ & $3.7 \%$ & $5.7 \%$ & $16.1 \%$ \\
\hline Vsb & 0.386100 & 0.386100 & 0.386100 & 0.386100 & 0.386100 \\
\hline Vmm & 0.426320 & 0.432184 & 0.424180 & 0.446141 & 0.577116 \\
\hline Vmb & 0.444084 & 0.450192 & 0.441854 & 0.464730 & 0.601163 \\
\hline VMA & $13.1 \%$ & $14.2 \%$ & $12.6 \%$ & $16.9 \%$ & $35.8 \%$ \\
\hline D/B & 0.76 & 0.87 & 0.72 & 1.12 & 3.17 \\
\hline VFA & $69 \%$ & $72 \%$ & $68 \%$ & $76 \%$ & $89 \%$ \\
\hline$\%$ Vbe & $9 \%$ & $10 \%$ & $9 \%$ & $13 \%$ & $32 \%$ \\
\hline$\%$ Vb & $12 \%$ & $13 \%$ & $11 \%$ & $15 \%$ & $34 \%$ \\
\hline
\end{tabular}

\begin{tabular}{|c|c|c|c|c|c|}
\hline $\begin{array}{l}\text { Film } \\
\text { Thickness } 6 \\
\mu \mathrm{m}\end{array}$ & $\begin{array}{l}\text { Edwards- } \\
\text { Hveem }\end{array}$ & Craus-Ishai & $\begin{array}{l}\text { Davg } \\
\text { method }\end{array}$ & $\begin{array}{l}\text { Measured } \\
\text { Sand }\end{array}$ & $\begin{array}{l}\text { Measured } \\
\text { Limestone }\end{array}$ \\
\hline Wbe & 0.030768 & 0.035254 & 0.029131 & 0.045931 & 0.146127 \\
\hline $\mathrm{Wb}$ & 0.042980 & 0.047466 & 0.041342 & 0.058142 & 0.158339 \\
\hline Vba & 0.011972 & 0.011972 & 0.011972 & 0.011972 & 0.011972 \\
\hline Vbe & 0.030165 & 0.034563 & 0.028560 & 0.045030 & 0.143262 \\
\hline $\mathrm{Vb}$ & 0.042137 & 0.046535 & 0.040532 & 0.057002 & 0.155234 \\
\hline $\mathrm{Wm}$ & 1.042980 & 1.047466 & 1.041342 & 1.058142 & 1.158339 \\
\hline $\mathrm{Pb}$ & $4.1 \%$ & $4.5 \%$ & $4.0 \%$ & $5.5 \%$ & $13.7 \%$ \\
\hline Pbe & $3.0 \%$ & $3.4 \%$ & $2.8 \%$ & $4.3 \%$ & $12.6 \%$ \\
\hline Vsb & 0.386100 & 0.386100 & 0.386100 & 0.386100 & 0.386100 \\
\hline Vmm & 0.416265 & 0.420663 & 0.414660 & 0.431131 & 0.529362 \\
\hline Vmb & 0.433610 & 0.438191 & 0.431937 & 0.449094 & 0.551419 \\
\hline VMA & $11.0 \%$ & $11.9 \%$ & $10.6 \%$ & $14.0 \%$ & $30.0 \%$ \\
\hline $\mathrm{D} / \mathrm{B}$ & 0.58 & 0.66 & 0.55 & 0.85 & 2.47 \\
\hline VFA & $63 \%$ & $66 \%$ & $62 \%$ & $71 \%$ & $87 \%$ \\
\hline$\%$ Vbe & $7 \%$ & $8 \%$ & $7 \%$ & $10 \%$ & $26 \%$ \\
\hline$\% \mathrm{Vb}$ & $10 \%$ & $11 \%$ & $9 \%$ & $13 \%$ & $28 \%$ \\
\hline
\end{tabular}

\begin{tabular}{|c|c|c|c|c|c|}
\cline { 2 - 6 } $\begin{array}{c}\text { Film } \\
\begin{array}{c}\text { Thickness 4 } \\
\mu \mathrm{m}\end{array}\end{array}$ & $\begin{array}{c}\text { Edwards- } \\
\text { Hveem }\end{array}$ & Craus-Ishai & $\begin{array}{c}\text { Davg } \\
\text { method }\end{array}$ & $\begin{array}{c}\text { Measured } \\
\text { Sand }\end{array}$ & $\begin{array}{c}\text { Measured } \\
\text { Limestone }\end{array}$ \\
\hline Wbe & 0.020512 & 0.023503 & 0.019421 & 0.030621 & 0.097418 \\
\hline $\mathrm{Wb}$ & 0.032724 & 0.035714 & 0.031632 & 0.042832 & 0.109630 \\
\hline $\mathrm{Vba}$ & 0.011972 & 0.011972 & 0.011972 & 0.011972 & 0.011972 \\
\hline $\mathrm{Vbe}$ & 0.020110 & 0.023042 & 0.019040 & 0.030020 & 0.095508 \\
\hline $\mathrm{Vb}$ & 0.032082 & 0.035014 & 0.031012 & 0.041992 & 0.107480 \\
\hline $\mathrm{Wm}$ & 1.032724 & 1.035714 & 1.031632 & 1.042832 & 1.109630 \\
\hline $\mathrm{Pb}$ & $3.2 \%$ & $3.4 \%$ & $3.1 \%$ & $4.1 \%$ & $9.9 \%$ \\
\hline $\mathrm{Pbe}$ & $2.0 \%$ & $2.3 \%$ & $1.9 \%$ & $2.9 \%$ & $8.8 \%$ \\
\hline $\mathrm{Vsb}$ & 0.386100 & 0.386100 & 0.386100 & 0.386100 & 0.386100 \\
\hline $\mathrm{Vmm}$ & 0.406210 & 0.409142 & 0.405140 & 0.416121 & 0.481608 \\
\hline $\mathrm{Vmb}$ & 0.423136 & 0.426190 & 0.422021 & 0.433459 & 0.501675 \\
\hline $\mathrm{VMA}$ & $8.8 \%$ & $9.4 \%$ & $8.5 \%$ & $10.9 \%$ & $23.0 \%$ \\
\hline $\mathrm{D} / \mathrm{B}$ & 0.39 & 0.44 & 0.37 & 0.58 & 1.72 \\
\hline $\mathrm{VFA}$ & $54 \%$ & $57 \%$ & $53 \%$ & $63 \%$ & $83 \%$ \\
\hline$\% \mathrm{Vbe}$ & $5 \%$ & $5 \%$ & $5 \%$ & $7 \%$ & $19 \%$ \\
\hline$\% \mathrm{Vb}$ & $8 \%$ & $8 \%$ & $7 \%$ & $10 \%$ & $21 \%$ \\
\hline & & & & & \\
\hline
\end{tabular}

\begin{tabular}{|c|c|c|c|c|c|}
\hline $\begin{array}{c}\text { Film } \\
\text { Thickness } 2 \\
\mu \mathrm{m}\end{array}$ & $\begin{array}{c}\text { Edwards- } \\
\text { Hveem }\end{array}$ & Craus-Ishai & $\begin{array}{l}\text { Davg } \\
\text { method }\end{array}$ & $\begin{array}{c}\text { Measured } \\
\text { Sand }\end{array}$ & $\begin{array}{l}\text { Measured } \\
\text { Limestone }\end{array}$ \\
\hline Wbe & 0.010256 & 0.011751 & 0.009710 & 0.015310 & 0.048709 \\
\hline $\mathrm{Wb}$ & 0.022468 & 0.023963 & 0.021922 & 0.027522 & 0.060921 \\
\hline Vba & 0.011972 & 0.011972 & 0.011972 & 0.011972 & 0.011972 \\
\hline Vbe & 0.010055 & 0.011521 & 0.009520 & 0.015010 & 0.047754 \\
\hline $\mathrm{Vb}$ & 0.022027 & 0.023493 & 0.021492 & 0.026982 & 0.059726 \\
\hline $\mathrm{Wm}$ & 1.022468 & 1.023963 & 1.021922 & 1.027522 & 1.060921 \\
\hline $\mathrm{Pb}$ & $2.2 \%$ & $2.3 \%$ & $2.1 \%$ & $2.7 \%$ & $5.7 \%$ \\
\hline Pbe & $1.0 \%$ & $1.1 \%$ & $1.0 \%$ & $1.5 \%$ & $4.6 \%$ \\
\hline Vsb & 0.386100 & 0.386100 & 0.386100 & 0.386100 & 0.386100 \\
\hline Vmm & 0.396155 & 0.397621 & 0.395620 & 0.401110 & 0.433854 \\
\hline $\mathrm{Vmb}$ & 0.412662 & 0.414189 & 0.412104 & 0.417823 & 0.451932 \\
\hline VMA & $6.4 \%$ & $6.8 \%$ & $6.3 \%$ & $7.6 \%$ & $14.6 \%$ \\
\hline $\mathrm{D} / \mathrm{B}$ & 0.20 & 0.23 & 0.19 & 0.29 & 0.90 \\
\hline VFA & $38 \%$ & $41 \%$ & $37 \%$ & $47 \%$ & $73 \%$ \\
\hline$\%$ Vbe & $2 \%$ & $3 \%$ & $2 \%$ & $4 \%$ & $11 \%$ \\
\hline$\% \mathrm{Vb}$ & $5 \%$ & $6 \%$ & $5 \%$ & $6 \%$ & $13 \%$ \\
\hline
\end{tabular}


TABLE E.5 VOLUMETRIC ANALYSIS FOR 19 mm GRADATION \#1

\begin{tabular}{|c|c|c|c|c|c|}
\hline $\begin{array}{c}\text { Film } \\
\text { Thickness } 10 \\
\mu \mathrm{m}\end{array}$ & $\begin{array}{l}\text { Edwards- } \\
\text { Hveem }\end{array}$ & Craus-Ishai & $\begin{array}{l}\text { Davg } \\
\text { method }\end{array}$ & $\begin{array}{l}\text { Measured } \\
\text { Sand }\end{array}$ & $\begin{array}{l}\text { Measured } \\
\text { Limestone }\end{array}$ \\
\hline Wbe & 0.055490 & 0.062938 & 0.051425 & 0.075814 & 0.242918 \\
\hline $\mathrm{Wb}$ & 0.067204 & 0.074652 & 0.063139 & 0.087528 & 0.254632 \\
\hline Vba & 0.011484 & 0.011484 & 0.011484 & 0.011484 & 0.011484 \\
\hline Vbe & 0.054402 & 0.061704 & 0.050417 & 0.074328 & 0.238155 \\
\hline $\mathrm{Vb}$ & 0.065886 & 0.073188 & 0.061901 & 0.085812 & 0.249639 \\
\hline $\mathrm{Wm}$ & 1.067204 & 1.074652 & 1.063139 & 1.087528 & 1.254632 \\
\hline $\mathrm{Pb}$ & $6.3 \%$ & $6.9 \%$ & $5.9 \%$ & $8.0 \%$ & $20.3 \%$ \\
\hline Pbe & $5.2 \%$ & $5.9 \%$ & $4.8 \%$ & $7.0 \%$ & $19.4 \%$ \\
\hline $\mathrm{Vsb}$ & 0.370370 & 0.370370 & 0.370370 & 0.370370 & 0.370370 \\
\hline Vmm & 0.424772 & 0.432074 & 0.420787 & 0.444698 & 0.608525 \\
\hline Vmb & 0.442471 & 0.450077 & 0.438320 & 0.463227 & 0.633881 \\
\hline VMA & $16.3 \%$ & $17.7 \%$ & $15.5 \%$ & $20.0 \%$ & $41.6 \%$ \\
\hline $\mathrm{D} / \mathrm{B}$ & 1.04 & 1.17 & 0.97 & 1.39 & 3.87 \\
\hline VFA & $75 \%$ & $77 \%$ & $74 \%$ & $80 \%$ & $90 \%$ \\
\hline$\%$ Vbe & $12 \%$ & $14 \%$ & $12 \%$ & $16 \%$ & $38 \%$ \\
\hline$\% \mathrm{Vb}$ & $15 \%$ & $16 \%$ & $14 \%$ & $19 \%$ & $39 \%$ \\
\hline
\end{tabular}

\begin{tabular}{|c|c|c|c|c|c|}
\hline $\begin{array}{c}\text { Film } \\
\text { Thickness } 8 \\
\mu \mathrm{m}\end{array}$ & $\begin{array}{c}\text { Edwards- } \\
\text { Hveem }\end{array}$ & Craus-Ishai & $\begin{array}{l}\text { Davg } \\
\text { method }\end{array}$ & $\begin{array}{l}\text { Measured } \\
\text { Sand }\end{array}$ & $\begin{array}{l}\text { Measured } \\
\text { Limestone }\end{array}$ \\
\hline Wbe & 0.044392 & 0.050350 & 0.041140 & 0.060651 & 0.194334 \\
\hline $\mathrm{Wb}$ & 0.056106 & 0.062064 & 0.052854 & 0.072366 & 0.206048 \\
\hline Vba & 0.011484 & 0.011484 & 0.011484 & 0.011484 & 0.011484 \\
\hline Vbe & 0.043522 & 0.049363 & 0.040334 & 0.059462 & 0.190524 \\
\hline $\mathrm{Vb}$ & 0.055006 & 0.060848 & 0.051818 & 0.070947 & 0.202008 \\
\hline $\mathrm{Wm}$ & 1.056106 & 1.062064 & 1.052854 & 1.072366 & 1.206048 \\
\hline $\mathrm{Pb}$ & $5.3 \%$ & $5.8 \%$ & $5.0 \%$ & $6.7 \%$ & $17.1 \%$ \\
\hline Pbe & $4.2 \%$ & $4.7 \%$ & $3.9 \%$ & $5.7 \%$ & $16.1 \%$ \\
\hline Vsb & 0.370370 & 0.370370 & 0.370370 & 0.370370 & 0.370370 \\
\hline Vmm & 0.413892 & 0.419734 & 0.410704 & 0.429833 & 0.560894 \\
\hline Vmb & 0.431138 & 0.437222 & 0.427817 & 0.447742 & 0.584265 \\
\hline VMA & $14.1 \%$ & $15.3 \%$ & $13.4 \%$ & $17.3 \%$ & $36.6 \%$ \\
\hline $\mathrm{D} / \mathrm{B}$ & 0.84 & 0.95 & 0.78 & 1.13 & 3.22 \\
\hline VFA & $72 \%$ & $74 \%$ & $70 \%$ & $77 \%$ & $89 \%$ \\
\hline$\%$ Vbe & $10 \%$ & $11 \%$ & $9 \%$ & $13 \%$ & $33 \%$ \\
\hline$\% \mathrm{Vb}$ & $13 \%$ & $14 \%$ & $12 \%$ & $16 \%$ & $35 \%$ \\
\hline
\end{tabular}

\begin{tabular}{c|c|c|c|c|c|}
\cline { 2 - 6 } $\begin{array}{c}\text { Film } \\
\begin{array}{c}\text { Thickness } 6 \\
\mu \mathrm{m}\end{array}\end{array}$ & $\begin{array}{c}\text { Edwards- } \\
\text { Hveem }\end{array}$ & Craus-Ishai & $\begin{array}{c}\text { Davg } \\
\text { method }\end{array}$ & $\begin{array}{c}\text { Measured } \\
\text { Sand }\end{array}$ & $\begin{array}{c}\text { Measured } \\
\text { Limestone }\end{array}$ \\
\hline Wbe & 0.033294 & 0.037763 & 0.030855 & 0.045489 & 0.145751 \\
\hline Wb & 0.045008 & 0.049477 & 0.042569 & 0.057203 & 0.157465 \\
\hline Vba & 0.011484 & 0.011484 & 0.011484 & 0.011484 & 0.011484 \\
\hline Vbe & 0.032641 & 0.037022 & 0.030250 & 0.044597 & 0.142893 \\
\hline Vb & 0.044126 & 0.048507 & 0.041735 & 0.056081 & 0.154377 \\
\hline Wm & 1.045008 & 1.049477 & 1.042569 & 1.057203 & 1.157465 \\
\hline $\mathrm{Pb}$ & $4.3 \%$ & $4.7 \%$ & $4.1 \%$ & $5.4 \%$ & $13.6 \%$ \\
\hline $\mathrm{Pbe}$ & $3.2 \%$ & $3.6 \%$ & $3.0 \%$ & $4.3 \%$ & $12.6 \%$ \\
\hline Vsb & 0.370370 & 0.370370 & 0.370370 & 0.370370 & 0.370370 \\
\hline Vmm & 0.403012 & 0.407393 & 0.400621 & 0.414967 & 0.513263 \\
\hline Vmb & 0.419804 & 0.424367 & 0.417313 & 0.432257 & 0.534649 \\
\hline VMA & $11.8 \%$ & $12.7 \%$ & $11.2 \%$ & $14.3 \%$ & $30.7 \%$ \\
\hline $\mathrm{D} / \mathrm{B}$ & 0.64 & 0.72 & 0.59 & 0.86 & 2.52 \\
\hline $\mathrm{VFA}$ & $66 \%$ & $69 \%$ & $64 \%$ & $72 \%$ & $87 \%$ \\
\hline$\% \mathrm{Vbe}$ & $8 \%$ & $9 \%$ & $7 \%$ & $10 \%$ & $27 \%$ \\
\hline$\%$ Vb & $11 \%$ & $11 \%$ & $10 \%$ & $13 \%$ & $29 \%$ \\
\hline
\end{tabular}

\begin{tabular}{|c|c|c|c|c|c|}
\hline $\begin{array}{c}\text { Film } \\
\text { Thickness } 4 \\
\mu \mathrm{m}\end{array}$ & $\begin{array}{c}\text { Edwards- } \\
\text { Hveem }\end{array}$ & Craus-Ishai & $\begin{array}{l}\text { Davg } \\
\text { method }\end{array}$ & $\begin{array}{l}\text { Measured } \\
\text { Sand }\end{array}$ & $\begin{array}{l}\text { Measured } \\
\text { Limestone }\end{array}$ \\
\hline Wbe & 0.022196 & 0.025175 & 0.020570 & 0.030326 & 0.097167 \\
\hline $\mathrm{Wb}$ & 0.033910 & 0.036889 & 0.032284 & 0.042040 & 0.108881 \\
\hline Vba & 0.011484 & 0.011484 & 0.011484 & 0.011484 & 0.011484 \\
\hline Vbe & 0.021761 & 0.024682 & 0.020167 & 0.029731 & 0.095262 \\
\hline $\mathrm{Vb}$ & 0.033245 & 0.036166 & 0.031651 & 0.041215 & 0.106746 \\
\hline Wm & 1.033910 & 1.036889 & 1.032284 & 1.042040 & 1.108881 \\
\hline $\mathrm{Pb}$ & $3.3 \%$ & $3.6 \%$ & $3.1 \%$ & $4.0 \%$ & $9.8 \%$ \\
\hline Pbe & $2.1 \%$ & $2.4 \%$ & $2.0 \%$ & $2.9 \%$ & $8.8 \%$ \\
\hline Vsb & 0.370370 & 0.370370 & 0.370370 & 0.370370 & 0.370370 \\
\hline Vmm & 0.392131 & 0.395052 & 0.390537 & 0.400101 & 0.465632 \\
\hline Vmb & 0.408470 & 0.411512 & 0.406810 & 0.416772 & 0.485034 \\
\hline VMA & $9.3 \%$ & $10.0 \%$ & $9.0 \%$ & $11.1 \%$ & $23.6 \%$ \\
\hline$D / B$ & 0.43 & 0.49 & 0.40 & 0.58 & 1.75 \\
\hline VFA & $57 \%$ & $60 \%$ & $55 \%$ & $64 \%$ & $83 \%$ \\
\hline$\%$ Vbe & $5 \%$ & $6 \%$ & $5 \%$ & $7 \%$ & $20 \%$ \\
\hline$\% \mathrm{Vb}$ & $8 \%$ & $9 \%$ & $8 \%$ & $10 \%$ & $22 \%$ \\
\hline
\end{tabular}

\begin{tabular}{c|c|c|c|c|c|}
\cline { 2 - 6 } $\begin{array}{c}\text { Film } \\
\begin{array}{c}\text { Thickness 2 } \\
\text { mm }\end{array}\end{array}$ & $\begin{array}{c}\text { Edwards- } \\
\text { Hveem }\end{array}$ & Craus-Ishai & $\begin{array}{c}\text { Davg } \\
\text { method }\end{array}$ & $\begin{array}{c}\text { Measured } \\
\text { Sand }\end{array}$ & $\begin{array}{c}\text { Measured } \\
\text { Limestone }\end{array}$ \\
\hline Wbe & 0.011098 & 0.012588 & 0.010285 & 0.015163 & 0.048584 \\
\hline Wb & 0.022812 & 0.024302 & 0.021999 & 0.026877 & 0.060298 \\
\hline Vba & 0.011484 & 0.011484 & 0.011484 & 0.011484 & 0.011484 \\
\hline Vbe & 0.010880 & 0.012341 & 0.010083 & 0.014866 & 0.047631 \\
\hline Vb & 0.022365 & 0.023825 & 0.021568 & 0.026350 & 0.059115 \\
\hline Wm & 1.022812 & 1.024302 & 1.021999 & 1.026877 & 1.060298 \\
\hline $\mathrm{Pb}$ & $2.2 \%$ & $2.4 \%$ & $2.2 \%$ & $2.6 \%$ & $5.7 \%$ \\
\hline $\mathrm{Pbe}$ & $1.1 \%$ & $1.2 \%$ & $1.0 \%$ & $1.5 \%$ & $4.6 \%$ \\
\hline $\mathrm{Vsb}$ & 0.370370 & 0.370370 & 0.370370 & 0.370370 & 0.370370 \\
\hline $\mathrm{Vmm}$ & 0.381251 & 0.382711 & 0.380454 & 0.385236 & 0.418001 \\
\hline $\mathrm{Vmb}$ & 0.397136 & 0.398657 & 0.396306 & 0.401287 & 0.435418 \\
\hline $\mathrm{VMA}$ & $6.7 \%$ & $7.1 \%$ & $6.5 \%$ & $7.7 \%$ & $14.9 \%$ \\
\hline $\mathrm{D} / \mathrm{B}$ & 0.22 & 0.25 & 0.20 & 0.30 & 0.92 \\
\hline $\mathrm{VFA}$ & $41 \%$ & $44 \%$ & $39 \%$ & $48 \%$ & $73 \%$ \\
\hline$\% \mathrm{Vbe}$ & $3 \%$ & $3 \%$ & $3 \%$ & $4 \%$ & $11 \%$ \\
\hline$\% \mathrm{Vb}$ & $6 \%$ & $6 \%$ & $5 \%$ & $7 \%$ & $14 \%$ \\
\hline
\end{tabular}


TABLE E.6 VOLUMETRIC ANALYSIS FOR 19 mm GRADATION \#2

\begin{tabular}{|c|c|c|c|c|c|}
\hline $\begin{array}{c}\text { Film } \\
\text { Thickness } 10 \\
\mu \mathrm{m}\end{array}$ & $\begin{array}{l}\text { Edwards- } \\
\text { Hveem }\end{array}$ & Craus-Ishai & $\begin{array}{l}\text { Davg } \\
\text { method }\end{array}$ & $\begin{array}{c}\text { Measured } \\
\text { Sand }\end{array}$ & $\begin{array}{l}\text { Measured } \\
\text { Limestone }\end{array}$ \\
\hline Wbe & 0.063229 & 0.073369 & 0.056346 & 0.065622 & 0.210618 \\
\hline $\mathrm{Wb}$ & 0.075074 & 0.085215 & 0.068192 & 0.077467 & 0.222463 \\
\hline Vba & 0.011613 & 0.011613 & 0.011613 & 0.011613 & 0.011613 \\
\hline Vbe & 0.061989 & 0.071930 & 0.055241 & 0.064335 & 0.206488 \\
\hline $\mathrm{Vb}$ & 0.073602 & 0.083544 & 0.066854 & 0.075948 & 0.218101 \\
\hline $\mathrm{Wm}$ & 1.075074 & 1.085215 & 1.068192 & 1.077467 & 1.222463 \\
\hline $\mathrm{Pb}$ & $7.0 \%$ & $7.9 \%$ & $6.4 \%$ & $7.2 \%$ & $18.2 \%$ \\
\hline Pbe & $5.9 \%$ & $6.8 \%$ & $5.3 \%$ & $6.1 \%$ & $17.2 \%$ \\
\hline Vsb & 0.374532 & 0.374532 & 0.374532 & 0.374532 & 0.374532 \\
\hline Vmm & 0.436521 & 0.446462 & 0.429773 & 0.438867 & 0.581020 \\
\hline $\mathrm{Vmb}$ & 0.454709 & 0.465065 & 0.447680 & 0.457153 & 0.605229 \\
\hline VMA & $17.6 \%$ & $19.5 \%$ & $16.3 \%$ & $18.1 \%$ & $38.1 \%$ \\
\hline $\mathrm{D} / \mathrm{B}$ & 1.47 & 1.69 & 1.32 & 1.52 & 4.31 \\
\hline VFA & $77 \%$ & $79 \%$ & $76 \%$ & $78 \%$ & $90 \%$ \\
\hline$\%$ Vbe & $14 \%$ & $15 \%$ & $12 \%$ & $14 \%$ & $34 \%$ \\
\hline$\% \mathrm{Vb}$ & $16 \%$ & $18 \%$ & $15 \%$ & $17 \%$ & $36 \%$ \\
\hline $\begin{array}{c}\text { Film } \\
\text { Thickness } 6 \\
\mu \mathrm{m}\end{array}$ & $\begin{array}{l}\text { Edwards- } \\
\text { Hveem }\end{array}$ & Craus-Ishai & $\begin{array}{l}\text { Davg } \\
\text { method }\end{array}$ & $\begin{array}{l}\text { Measured } \\
\text { Sand }\end{array}$ & $\begin{array}{l}\text { Measured } \\
\text { Limestone }\end{array}$ \\
\hline Wbe & 0.037937 & 0.044021 & 0.033808 & 0.039373 & 0.126371 \\
\hline $\mathrm{Wb}$ & 0.049783 & 0.055867 & 0.045653 & 0.051219 & 0.138216 \\
\hline Vba & 0.011613 & 0.011613 & 0.011613 & 0.011613 & 0.011613 \\
\hline Vbe & 0.037193 & 0.043158 & 0.033145 & 0.038601 & 0.123893 \\
\hline $\mathrm{Vb}$ & 0.048807 & 0.054772 & 0.044758 & 0.050214 & 0.135506 \\
\hline Wm & 1.049783 & 1.055867 & 1.045653 & 1.051219 & 1.138216 \\
\hline $\mathrm{Pb}$ & $4.7 \%$ & $5.3 \%$ & $4.4 \%$ & $4.9 \%$ & $12.1 \%$ \\
\hline Pbe & $3.6 \%$ & $4.2 \%$ & $3.2 \%$ & $3.7 \%$ & $11.1 \%$ \\
\hline Vsb & 0.374532 & 0.374532 & 0.374532 & 0.374532 & 0.374532 \\
\hline Vmm & 0.411725 & 0.417690 & 0.407676 & 0.413133 & 0.498425 \\
\hline Vmb & 0.428880 & 0.435094 & 0.424663 & 0.430347 & 0.519192 \\
\hline VMA & $12.7 \%$ & $13.9 \%$ & $11.8 \%$ & $13.0 \%$ & $27.9 \%$ \\
\hline $\mathrm{D} / \mathrm{B}$ & 0.90 & 1.04 & 0.81 & 0.94 & 2.78 \\
\hline VFA & $68 \%$ & $71 \%$ & $66 \%$ & $69 \%$ & $86 \%$ \\
\hline$\%$ Vbe & $9 \%$ & $10 \%$ & $8 \%$ & $9 \%$ & $24 \%$ \\
\hline$\% \mathrm{Vb}$ & $11 \%$ & $13 \%$ & $11 \%$ & $12 \%$ & $26 \%$ \\
\hline
\end{tabular}

\begin{tabular}{|c|c|c|c|c|c|}
\hline $\begin{array}{c}\text { Film } \\
\text { Thickness } 8 \\
\mu \mathrm{m}\end{array}$ & $\begin{array}{l}\text { Edwards- } \\
\text { Hveem }\end{array}$ & Craus-Ishai & $\begin{array}{l}\text { Davg } \\
\text { method }\end{array}$ & $\begin{array}{l}\text { Measured } \\
\text { Sand }\end{array}$ & $\begin{array}{l}\text { Measured } \\
\text { Limestone }\end{array}$ \\
\hline Wbe & 0.050583 & 0.058695 & 0.045077 & 0.052497 & 0.168494 \\
\hline $\mathrm{Wb}$ & 0.062429 & 0.070541 & 0.056922 & 0.064343 & 0.180340 \\
\hline Vba & 0.011613 & 0.011613 & 0.011613 & 0.011613 & 0.011613 \\
\hline Vbe & 0.049591 & 0.057544 & 0.044193 & 0.051468 & 0.165190 \\
\hline $\mathrm{Vb}$ & 0.061205 & 0.069158 & 0.055806 & 0.063081 & 0.176804 \\
\hline Wm & 1.062429 & 1.070541 & 1.056922 & 1.064343 & 1.180340 \\
\hline $\mathrm{Pb}$ & $5.9 \%$ & $6.6 \%$ & $5.4 \%$ & $6.0 \%$ & $15.3 \%$ \\
\hline Pbe & $4.8 \%$ & $5.5 \%$ & $4.3 \%$ & $4.9 \%$ & $14.3 \%$ \\
\hline Vsb & 0.374532 & 0.374532 & 0.374532 & 0.374532 & 0.374532 \\
\hline Vmm & 0.424123 & 0.432076 & 0.418725 & 0.426000 & 0.539722 \\
\hline Vmb & 0.441795 & 0.450079 & 0.436172 & 0.443750 & 0.562210 \\
\hline VMA & $15.2 \%$ & $16.8 \%$ & $14.1 \%$ & $15.6 \%$ & $33.4 \%$ \\
\hline D/B & 1.19 & 1.37 & 1.07 & 1.23 & 3.57 \\
\hline VFA & $74 \%$ & $76 \%$ & $72 \%$ & $74 \%$ & $88 \%$ \\
\hline$\%$ Vbe & $11 \%$ & $13 \%$ & $10 \%$ & $12 \%$ & $29 \%$ \\
\hline$\% \mathrm{Vb}$ & $14 \%$ & $15 \%$ & $13 \%$ & $14 \%$ & $31 \%$ \\
\hline
\end{tabular}

\begin{tabular}{c|c|c|c|c|c|}
\cline { 2 - 6 } $\begin{array}{c}\text { Film } \\
\text { Thickness } 4 \\
\mu m\end{array}$ & $\begin{array}{c}\text { Edwards- } \\
\text { Hveem }\end{array}$ & Craus-Ishai & $\begin{array}{c}\text { Davg } \\
\text { method }\end{array}$ & $\begin{array}{c}\text { Measured } \\
\text { Sand }\end{array}$ & $\begin{array}{c}\text { Measured } \\
\text { Limestone }\end{array}$ \\
\hline Wbe & 0.025292 & 0.029348 & 0.022538 & 0.026249 & 0.084247 \\
\hline Wb & 0.037137 & 0.041193 & 0.034384 & 0.038094 & 0.096093 \\
\hline Vba & 0.011613 & 0.011613 & 0.011613 & 0.011613 & 0.011613 \\
\hline Vbe & 0.024796 & 0.028772 & 0.022096 & 0.025734 & 0.082595 \\
\hline Vb & 0.036409 & 0.040386 & 0.033710 & 0.037347 & 0.094209 \\
\hline Wm & 1.037137 & 1.041193 & 1.034384 & 1.038094 & 1.096093 \\
\hline $\mathrm{Pb}$ & $3.6 \%$ & $4.0 \%$ & $3.3 \%$ & $3.7 \%$ & $8.8 \%$ \\
\hline $\mathrm{Pbe}$ & $2.4 \%$ & $2.8 \%$ & $2.2 \%$ & $2.5 \%$ & $7.7 \%$ \\
\hline $\mathrm{Vsb}$ & 0.374532 & 0.374532 & 0.374532 & 0.374532 & 0.374532 \\
\hline $\mathrm{Vmm}$ & 0.399327 & 0.403304 & 0.396628 & 0.400266 & 0.457127 \\
\hline $\mathrm{Vmb}$ & 0.415966 & 0.420108 & 0.413154 & 0.416944 & 0.476174 \\
\hline $\mathrm{VMA}$ & $10.0 \%$ & $10.8 \%$ & $9.3 \%$ & $10.2 \%$ & $21.3 \%$ \\
\hline $\mathrm{D} / \mathrm{B}$ & 0.61 & 0.70 & 0.54 & 0.63 & 1.92 \\
\hline $\mathrm{VFA}$ & $60 \%$ & $63 \%$ & $57 \%$ & $61 \%$ & $81 \%$ \\
\hline$\% \mathrm{Vbe}$ & $6 \%$ & $7 \%$ & $5 \%$ & $6 \%$ & $17 \%$ \\
\hline$\% \mathrm{Vb}$ & $9 \%$ & $10 \%$ & $8 \%$ & $9 \%$ & $20 \%$ \\
\hline
\end{tabular}

\begin{tabular}{c|c|c|c|c|c|}
\cline { 2 - 6 } $\begin{array}{c}\text { Film } \\
\text { Thickness 2 } \\
\text { mm }\end{array}$ & $\begin{array}{c}\text { Edwards- } \\
\text { Hveem }\end{array}$ & Craus-Ishai & $\begin{array}{c}\text { Davg } \\
\text { method }\end{array}$ & $\begin{array}{c}\text { Measured } \\
\text { Sand }\end{array}$ & $\begin{array}{c}\text { Measured } \\
\text { Limestone }\end{array}$ \\
\hline Wbe & 0.012646 & 0.014674 & 0.011269 & 0.013124 & 0.042124 \\
\hline Wb & 0.024491 & 0.026519 & 0.023115 & 0.024970 & 0.053969 \\
\hline $\mathrm{Vba}$ & 0.011613 & 0.011613 & 0.011613 & 0.011613 & 0.011613 \\
\hline $\mathrm{Vbe}$ & 0.012398 & 0.014386 & 0.011048 & 0.012867 & 0.041298 \\
\hline $\mathrm{Vb}$ & 0.024011 & 0.025999 & 0.022662 & 0.024480 & 0.052911 \\
\hline $\mathrm{Wm}$ & 1.024491 & 1.026519 & 1.023115 & 1.024970 & 1.053969 \\
\hline $\mathrm{Pb}$ & $2.4 \%$ & $2.6 \%$ & $2.3 \%$ & $2.4 \%$ & $5.1 \%$ \\
\hline $\mathrm{Pbe}$ & $1.2 \%$ & $1.4 \%$ & $1.1 \%$ & $1.3 \%$ & $4.0 \%$ \\
\hline $\mathrm{Vsb}$ & 0.374532 & 0.374532 & 0.374532 & 0.374532 & 0.374532 \\
\hline $\mathrm{Vmm}$ & 0.386930 & 0.388918 & 0.385580 & 0.387399 & 0.415829 \\
\hline $\mathrm{Vmb}$ & 0.403052 & 0.405123 & 0.401646 & 0.403540 & 0.433156 \\
\hline $\mathrm{VMA}$ & $7.1 \%$ & $7.6 \%$ & $6.8 \%$ & $7.2 \%$ & $13.5 \%$ \\
\hline $\mathrm{D} / \mathrm{B}$ & 0.31 & 0.36 & 0.28 & 0.32 & 1.00 \\
\hline $\mathrm{VFA}$ & $43 \%$ & $47 \%$ & $41 \%$ & $44 \%$ & $70 \%$ \\
\hline$\% \mathrm{Vbe}$ & $3 \%$ & $4 \%$ & $3 \%$ & $3 \%$ & $10 \%$ \\
\hline$\% \mathrm{Vb}$ & $6 \%$ & $6 \%$ & $6 \%$ & $6 \%$ & $12 \%$ \\
\hline
\end{tabular}


TABLE E.7 VOLUMETRIC ANALYSIS FOR 19 mm GRADATION \#3

\begin{tabular}{|c|c|c|c|c|c|}
\hline $\begin{array}{c}\text { Film } \\
\text { Thickness } 10 \\
\mu \mathrm{m}\end{array}$ & $\begin{array}{l}\text { Edwards- } \\
\text { Hveem }\end{array}$ & Craus-Ishai & $\begin{array}{l}\text { Davg } \\
\text { method }\end{array}$ & $\begin{array}{l}\text { Measured } \\
\text { Sand }\end{array}$ & $\begin{array}{l}\text { Measured } \\
\text { Limestone }\end{array}$ \\
\hline Wbe & 0.042878 & 0.047598 & 0.041176 & 0.069502 & 0.232255 \\
\hline $\mathrm{Wb}$ & 0.054996 & 0.059716 & 0.053294 & 0.081620 & 0.244373 \\
\hline Vba & 0.011880 & 0.011880 & 0.011880 & 0.011880 & 0.011880 \\
\hline Vbe & 0.042037 & 0.046664 & 0.040369 & 0.068139 & 0.227701 \\
\hline $\mathrm{Vb}$ & 0.053917 & 0.058545 & 0.052249 & 0.080020 & 0.239581 \\
\hline Wm & 1.054996 & 1.059716 & 1.053294 & 1.081620 & 1.244373 \\
\hline $\mathrm{Pb}$ & $5.2 \%$ & $5.6 \%$ & $5.1 \%$ & $7.5 \%$ & $19.6 \%$ \\
\hline Pbe & $4.1 \%$ & $4.5 \%$ & $3.9 \%$ & $6.4 \%$ & $18.7 \%$ \\
\hline $\mathrm{Vsb}$ & 0.383142 & 0.383142 & 0.383142 & 0.383142 & 0.383142 \\
\hline Vmm & 0.425179 & 0.429806 & 0.423511 & 0.451281 & 0.610843 \\
\hline Vmb & 0.442895 & 0.447715 & 0.441157 & 0.470085 & 0.636294 \\
\hline VMA & $13.5 \%$ & $14.4 \%$ & $13.2 \%$ & $18.5 \%$ & $39.8 \%$ \\
\hline $\mathrm{D} / \mathrm{B}$ & 0.81 & 0.90 & 0.78 & 1.29 & 3.73 \\
\hline VFA & $70 \%$ & $72 \%$ & $70 \%$ & $78 \%$ & $90 \%$ \\
\hline$\%$ Vbe & $9 \%$ & $10 \%$ & $9 \%$ & $14 \%$ & $36 \%$ \\
\hline$\% \mathrm{Vb}$ & $12 \%$ & $13 \%$ & $12 \%$ & $17 \%$ & $38 \%$ \\
\hline
\end{tabular}

\begin{tabular}{|c|c|c|c|c|c|}
\hline $\begin{array}{c}\text { Film } \\
\text { Thickness } 8 \\
\mu \mathrm{m}\end{array}$ & $\begin{array}{l}\text { Edwards- } \\
\text { Hveem }\end{array}$ & Craus-Ishai & $\begin{array}{l}\text { Davg } \\
\text { method }\end{array}$ & $\begin{array}{l}\text { Measured } \\
\text { Sand }\end{array}$ & $\begin{array}{l}\text { Measured } \\
\text { Limestone }\end{array}$ \\
\hline Wbe & 0.034302 & 0.038078 & 0.032941 & 0.055602 & 0.185804 \\
\hline $\mathrm{Wb}$ & 0.046420 & 0.050196 & 0.045059 & 0.067720 & 0.197922 \\
\hline Vba & 0.011880 & 0.011880 & 0.011880 & 0.011880 & 0.011880 \\
\hline Vbe & 0.033630 & 0.037331 & 0.032295 & 0.054512 & 0.182161 \\
\hline $\mathrm{Vb}$ & 0.045510 & 0.049212 & 0.044176 & 0.066392 & 0.194041 \\
\hline $\mathrm{Wm}$ & 1.046420 & 1.050196 & 1.045059 & 1.067720 & 1.197922 \\
\hline $\mathrm{Pb}$ & $4.4 \%$ & $4.8 \%$ & $4.3 \%$ & $6.3 \%$ & $16.5 \%$ \\
\hline Pbe & $3.3 \%$ & $3.6 \%$ & $3.2 \%$ & $5.2 \%$ & $15.5 \%$ \\
\hline Vsb & 0.383142 & 0.383142 & 0.383142 & 0.383142 & 0.383142 \\
\hline Vmm & 0.416771 & 0.420473 & 0.415437 & 0.437653 & 0.565302 \\
\hline Vmb & 0.434137 & 0.437993 & 0.432747 & 0.455889 & 0.588857 \\
\hline VMA & $11.7 \%$ & $12.5 \%$ & $11.5 \%$ & $16.0 \%$ & $34.9 \%$ \\
\hline $\mathrm{D} / \mathrm{B}$ & 0.66 & 0.73 & 0.63 & 1.04 & 3.10 \\
\hline VFA & $66 \%$ & $68 \%$ & $65 \%$ & $75 \%$ & $89 \%$ \\
\hline$\%$ Vbe & $8 \%$ & $9 \%$ & $7 \%$ & $12 \%$ & $31 \%$ \\
\hline$\% \mathrm{Vb}$ & $10 \%$ & $11 \%$ & $10 \%$ & $15 \%$ & $33 \%$ \\
\hline
\end{tabular}

\begin{tabular}{|c|c|c|c|c|c|}
\hline $\begin{array}{c}\text { Film } \\
\text { Thickness } 6 \\
\mu \mathrm{m}\end{array}$ & $\begin{array}{c}\text { Edwards- } \\
\text { Hveem }\end{array}$ & Craus-Ishai & $\begin{array}{l}\text { Davg } \\
\text { method }\end{array}$ & $\begin{array}{l}\text { Measured } \\
\text { Sand }\end{array}$ & $\begin{array}{l}\text { Measured } \\
\text { Limestone }\end{array}$ \\
\hline Wbe & 0.025727 & 0.028559 & 0.024706 & 0.041701 & 0.139353 \\
\hline $\mathrm{Wb}$ & 0.037845 & 0.040677 & 0.036824 & 0.053819 & 0.151471 \\
\hline Vba & 0.011880 & 0.011880 & 0.011880 & 0.011880 & 0.011880 \\
\hline Vbe & 0.025222 & 0.027999 & 0.024221 & 0.040884 & 0.136620 \\
\hline $\mathrm{Vb}$ & 0.037103 & 0.039879 & 0.036102 & 0.052764 & 0.148501 \\
\hline Wm & 1.037845 & 1.040677 & 1.036824 & 1.053819 & 1.151471 \\
\hline $\mathrm{Pb}$ & $3.6 \%$ & $3.9 \%$ & $3.6 \%$ & $5.1 \%$ & $13.2 \%$ \\
\hline Pbe & $2.5 \%$ & $2.7 \%$ & $2.4 \%$ & $4.0 \%$ & $12.1 \%$ \\
\hline Vsb & 0.383142 & 0.383142 & 0.383142 & 0.383142 & 0.383142 \\
\hline Vmm & 0.408364 & 0.411140 & 0.407363 & 0.424025 & 0.519762 \\
\hline Vmb & 0.425379 & 0.428271 & 0.424337 & 0.441693 & 0.541419 \\
\hline VMA & $9.9 \%$ & $10.5 \%$ & $9.7 \%$ & $13.3 \%$ & $29.2 \%$ \\
\hline$D / B$ & 0.50 & 0.55 & 0.48 & 0.79 & 2.42 \\
\hline VFA & $60 \%$ & $62 \%$ & $59 \%$ & $70 \%$ & $86 \%$ \\
\hline$\%$ Vbe & $6 \%$ & $7 \%$ & $6 \%$ & $9 \%$ & $25 \%$ \\
\hline$\% \mathrm{Vb}$ & $9 \%$ & $9 \%$ & $9 \%$ & $12 \%$ & $27 \%$ \\
\hline
\end{tabular}

\begin{tabular}{|c|c|c|c|c|c|}
\hline $\begin{array}{c}\text { Film } \\
\text { Thickness } 4 \\
\mu \mathrm{m}\end{array}$ & $\begin{array}{c}\text { Edwards- } \\
\text { Hveem }\end{array}$ & Craus-Ishai & $\begin{array}{l}\text { Davg } \\
\text { method }\end{array}$ & $\begin{array}{l}\text { Measured } \\
\text { Sand }\end{array}$ & $\begin{array}{l}\text { Measured } \\
\text { Limestone }\end{array}$ \\
\hline Wbe & 0.017151 & 0.019039 & 0.016471 & 0.027801 & 0.092902 \\
\hline $\mathrm{Wb}$ & 0.029269 & 0.031157 & 0.028589 & 0.039919 & 0.105020 \\
\hline Vba & 0.011880 & 0.011880 & 0.011880 & 0.011880 & 0.011880 \\
\hline Vbe & 0.016815 & 0.018666 & 0.016148 & 0.027256 & 0.091080 \\
\hline $\mathrm{Vb}$ & 0.028695 & 0.030546 & 0.028028 & 0.039136 & 0.102961 \\
\hline Wm & 1.029269 & 1.031157 & 1.028589 & 1.039919 & 1.105020 \\
\hline $\mathrm{Pb}$ & $2.8 \%$ & $3.0 \%$ & $2.8 \%$ & $3.8 \%$ & $9.5 \%$ \\
\hline Pbe & $1.7 \%$ & $1.8 \%$ & $1.6 \%$ & $2.7 \%$ & $8.4 \%$ \\
\hline Vsb & 0.383142 & 0.383142 & 0.383142 & 0.383142 & 0.383142 \\
\hline Vmm & 0.399957 & 0.401807 & 0.399289 & 0.410398 & 0.474222 \\
\hline Vmb & 0.416621 & 0.418549 & 0.415926 & 0.427497 & 0.493981 \\
\hline VMA & $8.0 \%$ & $8.5 \%$ & $7.9 \%$ & $10.4 \%$ & $22.4 \%$ \\
\hline$D / B$ & 0.33 & 0.37 & 0.32 & 0.53 & 1.68 \\
\hline VFA & $50 \%$ & $53 \%$ & $49 \%$ & $61 \%$ & $82 \%$ \\
\hline$\%$ Vbe & $4 \%$ & $4 \%$ & $4 \%$ & $6 \%$ & $18 \%$ \\
\hline$\% \mathrm{Vb}$ & $7 \%$ & $7 \%$ & $7 \%$ & $9 \%$ & $21 \%$ \\
\hline
\end{tabular}

\begin{tabular}{c|c|c|c|c|c|}
\cline { 2 - 6 } $\begin{array}{c}\text { Film } \\
\begin{array}{c}\text { Thickness 2 } \\
\mu \mathrm{m}\end{array}\end{array}$ & $\begin{array}{c}\text { Edwards- } \\
\text { Hveem }\end{array}$ & Craus-Ishai & $\begin{array}{c}\text { Davg } \\
\text { method }\end{array}$ & $\begin{array}{c}\text { Measured } \\
\text { Sand }\end{array}$ & $\begin{array}{c}\text { Measured } \\
\text { Limestone }\end{array}$ \\
\hline Wbe & 0.008576 & 0.009520 & 0.008235 & 0.013900 & 0.046451 \\
\hline $\mathrm{Wb}$ & 0.020694 & 0.021637 & 0.020353 & 0.026018 & 0.058569 \\
\hline $\mathrm{Vba}$ & 0.011880 & 0.011880 & 0.011880 & 0.011880 & 0.011880 \\
\hline $\mathrm{Vbe}$ & 0.008407 & 0.009333 & 0.008074 & 0.013628 & 0.045540 \\
\hline $\mathrm{Vb}$ & 0.020288 & 0.021213 & 0.019954 & 0.025508 & 0.057421 \\
\hline $\mathrm{Wm}$ & 1.020694 & 1.021637 & 1.020353 & 1.026018 & 1.058569 \\
\hline $\mathrm{Pb}$ & $2.0 \%$ & $2.1 \%$ & $2.0 \%$ & $2.5 \%$ & $5.5 \%$ \\
\hline $\mathrm{Pbe}$ & $0.8 \%$ & $0.9 \%$ & $0.8 \%$ & $1.4 \%$ & $4.4 \%$ \\
\hline $\mathrm{Vsb}$ & 0.383142 & 0.383142 & 0.383142 & 0.383142 & 0.383142 \\
\hline $\mathrm{Vmm}$ & 0.391549 & 0.392475 & 0.391216 & 0.396770 & 0.428682 \\
\hline $\mathrm{Vmb}$ & 0.407864 & 0.408828 & 0.407516 & 0.413302 & 0.446544 \\
\hline $\mathrm{VMA}$ & $6.1 \%$ & $6.3 \%$ & $6.0 \%$ & $7.3 \%$ & $14.2 \%$ \\
\hline $\mathrm{D} / \mathrm{B}$ & 0.17 & 0.19 & 0.16 & 0.27 & 0.88 \\
\hline $\mathrm{VFA}$ & $34 \%$ & $36 \%$ & $33 \%$ & $45 \%$ & $72 \%$ \\
\hline$\% \mathrm{Vbe}$ & $2 \%$ & $2 \%$ & $2 \%$ & $3 \%$ & $10 \%$ \\
\hline$\% \mathrm{Vb}$ & $5 \%$ & $5 \%$ & $5 \%$ & $6 \%$ & $13 \%$ \\
\hline
\end{tabular}


TABLE E.8 VOLUMETRIC ANALYSIS FOR 19 mm GRADATION \#4

\begin{tabular}{|c|c|c|c|c|c|}
\hline $\begin{array}{c}\text { Film } \\
\text { Thickness } 10 \\
\mu \mathrm{m}\end{array}$ & $\begin{array}{l}\text { Edwards- } \\
\text { Hveem }\end{array}$ & Craus-Ishai & $\begin{array}{l}\text { Davg } \\
\text { method }\end{array}$ & $\begin{array}{c}\text { Measured } \\
\text { Sand }\end{array}$ & $\begin{array}{l}\text { Measured } \\
\text { Limestone }\end{array}$ \\
\hline Wbe & 0.040666 & 0.045567 & 0.037659 & 0.059333 & 0.186745 \\
\hline $\mathrm{Wb}$ & 0.052574 & 0.057475 & 0.049567 & 0.071242 & 0.198653 \\
\hline Vba & 0.011675 & 0.011675 & 0.011675 & 0.011675 & 0.011675 \\
\hline Vbe & 0.039868 & 0.044674 & $\begin{array}{l}0.036921 \\
\end{array}$ & 0.058170 & 0.183083 \\
\hline $\mathrm{Vb}$ & 0.051543 & 0.056348 & 0.048595 & 0.069845 & 0.194757 \\
\hline $\mathrm{Wm}$ & 1.052574 & 1.057475 & 1.049567 & 1.071242 & 1.198653 \\
\hline $\mathrm{Pb}$ & $5.0 \%$ & $5.4 \%$ & $4.7 \%$ & $6.7 \%$ & $16.6 \%$ \\
\hline Pbe & $3.9 \%$ & $4.3 \%$ & $3.6 \%$ & $5.5 \%$ & $15.6 \%$ \\
\hline Vsb & 0.376506 & 0.376506 & 0.376506 & 0.376506 & 0.376506 \\
\hline Vmm & 0.416374 & 0.421180 & 0.413427 & 0.434676 & 0.559589 \\
\hline $\mathrm{Vmb}$ & 0.433723 & 0.438729 & 0.430653 & 0.452788 & 0.582905 \\
\hline VMA & $13.2 \%$ & $14.2 \%$ & $12.6 \%$ & $16.8 \%$ & $35.4 \%$ \\
\hline $\mathrm{D} / \mathrm{B}$ & 0.99 & 1.10 & 0.92 & 1.42 & 3.99 \\
\hline VFA & $70 \%$ & $72 \%$ & $68 \%$ & $76 \%$ & $89 \%$ \\
\hline$\%$ Vbe & $9 \%$ & $10 \%$ & $9 \%$ & $13 \%$ & $31 \%$ \\
\hline$\% \mathrm{Vb}$ & $12 \%$ & $13 \%$ & $11 \%$ & $15 \%$ & $33 \%$ \\
\hline $\begin{array}{c}\text { Film } \\
\text { Thickness } 6 \\
\mu \mathrm{m}\end{array}$ & $\begin{array}{l}\text { Edwards- } \\
\text { Hveem }\end{array}$ & Craus-Ishai & $\begin{array}{l}\text { Davg } \\
\text { method }\end{array}$ & $\begin{array}{l}\text { Measured } \\
\text { Sand }\end{array}$ & $\begin{array}{l}\text { Measured } \\
\text { Limestone }\end{array}$ \\
\hline Wbe & 0.024399 & 0.027340 & 0.022596 & 0.035600 & 0.112047 \\
\hline $\mathrm{Wb}$ & 0.036307 & 0.039248 & 0.034504 & 0.047508 & 0.123955 \\
\hline Vba & 0.011675 & 0.011675 & 0.011675 & 0.011675 & 0.011675 \\
\hline Vbe & 0.023921 & 0.026804 & 0.022152 & 0.034902 & 0.109850 \\
\hline $\mathrm{Vb}$ & 0.035596 & 0.038479 & 0.033827 & 0.046577 & 0.121524 \\
\hline Wm & 1.036307 & 1.039248 & 1.034504 & 1.047508 & 1.123955 \\
\hline $\mathrm{Pb}$ & $3.5 \%$ & $3.8 \%$ & $3.3 \%$ & $4.5 \%$ & $11.0 \%$ \\
\hline Pbe & $2.4 \%$ & $2.6 \%$ & $2.2 \%$ & $3.4 \%$ & $10.0 \%$ \\
\hline Vsb & 0.376506 & 0.376506 & 0.376506 & 0.376506 & 0.376506 \\
\hline Vmm & 0.400427 & 0.403310 & 0.398658 & 0.411408 & 0.486356 \\
\hline Vmb & 0.417111 & 0.420115 & 0.415269 & 0.428550 & 0.506621 \\
\hline VMA & $9.7 \%$ & $10.4 \%$ & $9.3 \%$ & $12.1 \%$ & $25.7 \%$ \\
\hline $\mathrm{D} / \mathrm{B}$ & 0.60 & 0.67 & 0.56 & 0.87 & 2.56 \\
\hline VFA & $59 \%$ & $61 \%$ & $57 \%$ & $67 \%$ & $84 \%$ \\
\hline$\%$ Vbe & $6 \%$ & $6 \%$ & $5 \%$ & $8 \%$ & $22 \%$ \\
\hline$\% \mathrm{Vb}$ & $9 \%$ & $9 \%$ & $8 \%$ & $11 \%$ & $24 \%$ \\
\hline
\end{tabular}

\begin{tabular}{|c|c|c|c|c|c|}
\hline $\begin{array}{c}\text { Film } \\
\text { Thickness } 8 \\
\mu \mathrm{m}\end{array}$ & $\begin{array}{l}\text { Edwards- } \\
\text { Hveem }\end{array}$ & Craus-Ishai & $\begin{array}{l}\text { Davg } \\
\text { method }\end{array}$ & $\begin{array}{c}\text { Measured } \\
\text { Sand }\end{array}$ & $\begin{array}{l}\text { Measured } \\
\text { Limestone }\end{array}$ \\
\hline Wbe & 0.032533 & 0.036454 & 0.030127 & 0.047467 & 0.149396 \\
\hline $\mathrm{Wb}$ & 0.044441 & 0.048362 & 0.042035 & 0.059375 & 0.161304 \\
\hline Vba & 0.011675 & 0.011675 & 0.011675 & 0.011675 & 0.011675 \\
\hline Vbe & 0.031895 & 0.035739 & 0.029537 & 0.046536 & 0.146466 \\
\hline $\mathrm{Vb}$ & 0.043569 & 0.047414 & 0.041211 & 0.058211 & 0.158141 \\
\hline Wm & 1.044441 & 1.048362 & 1.042035 & 1.059375 & 1.161304 \\
\hline $\mathrm{Pb}$ & $4.3 \%$ & $4.6 \%$ & $4.0 \%$ & $5.6 \%$ & $13.9 \%$ \\
\hline Pbe & $3.1 \%$ & $3.5 \%$ & $2.9 \%$ & $4.5 \%$ & $12.9 \%$ \\
\hline Vsb & 0.376506 & 0.376506 & 0.376506 & 0.376506 & 0.376506 \\
\hline Vmm & 0.408401 & 0.412245 & 0.406043 & 0.423042 & 0.522972 \\
\hline Vmb & 0.425417 & 0.429422 & 0.422961 & 0.440669 & 0.544763 \\
\hline VMA & $11.5 \%$ & $12.3 \%$ & $11.0 \%$ & $14.6 \%$ & $30.9 \%$ \\
\hline D/B & 0.80 & 0.89 & 0.74 & 1.15 & 3.30 \\
\hline VFA & $65 \%$ & $68 \%$ & $64 \%$ & $73 \%$ & $87 \%$ \\
\hline$\%$ Vbe & $7 \%$ & $8 \%$ & $7 \%$ & $11 \%$ & $27 \%$ \\
\hline$\% \mathrm{Vb}$ & $10 \%$ & $11 \%$ & $10 \%$ & $13 \%$ & $29 \%$ \\
\hline
\end{tabular}

\begin{tabular}{c|c|c|c|c|c|}
\cline { 2 - 6 } $\begin{array}{c}\text { Film } \\
\text { Thickness } 4 \\
\mu m\end{array}$ & $\begin{array}{c}\text { Edwards- } \\
\text { Hveem }\end{array}$ & Craus-Ishai & $\begin{array}{c}\text { Davg } \\
\text { method }\end{array}$ & $\begin{array}{c}\text { Measured } \\
\text { Sand }\end{array}$ & $\begin{array}{c}\text { Measured } \\
\text { Limestone }\end{array}$ \\
\hline Wbe & 0.016266 & 0.018227 & 0.015064 & 0.023733 & 0.074698 \\
\hline Wb & 0.028174 & 0.030135 & 0.026972 & 0.035641 & 0.086606 \\
\hline Vba & 0.011675 & 0.011675 & 0.011675 & 0.011675 & 0.011675 \\
\hline Vbe & 0.015947 & 0.017870 & 0.014768 & 0.023268 & 0.073233 \\
\hline Vb & 0.027622 & 0.029544 & 0.026443 & 0.034943 & 0.084908 \\
\hline Wm & 1.028174 & 1.030135 & 1.026972 & 1.035641 & 1.086606 \\
\hline $\mathrm{Pb}$ & $2.7 \%$ & $2.9 \%$ & $2.6 \%$ & $3.4 \%$ & $8.0 \%$ \\
\hline $\mathrm{Pbe}$ & $1.6 \%$ & $1.8 \%$ & $1.5 \%$ & $2.3 \%$ & $6.9 \%$ \\
\hline $\mathrm{Vsb}$ & 0.376506 & 0.376506 & 0.376506 & 0.376506 & 0.376506 \\
\hline $\mathrm{Vmm}$ & 0.392453 & 0.394376 & 0.391274 & 0.399774 & 0.449739 \\
\hline $\mathrm{Vmb}$ & 0.408806 & 0.410808 & 0.407577 & 0.416431 & 0.468478 \\
\hline $\mathrm{VMA}$ & $7.9 \%$ & $8.3 \%$ & $7.6 \%$ & $9.6 \%$ & $19.6 \%$ \\
\hline $\mathrm{D} / \mathrm{B}$ & 0.41 & 0.45 & 0.38 & 0.59 & 1.76 \\
\hline $\mathrm{VFA}$ & $49 \%$ & $52 \%$ & $48 \%$ & $58 \%$ & $80 \%$ \\
\hline$\% \mathrm{Vbe}$ & $4 \%$ & $4 \%$ & $4 \%$ & $6 \%$ & $16 \%$ \\
\hline$\% \mathrm{Vb}$ & $7 \%$ & $7 \%$ & $6 \%$ & $8 \%$ & $18 \%$ \\
\hline
\end{tabular}

\begin{tabular}{|c|c|c|c|c|c|}
\hline $\begin{array}{c}\text { Film } \\
\text { Thickness } 2 \\
\mu \mathrm{m}\end{array}$ & $\begin{array}{c}\text { Edwards- } \\
\text { Hveem }\end{array}$ & Craus-Ishai & $\begin{array}{l}\text { Davg } \\
\text { method }\end{array}$ & $\begin{array}{l}\text { Measured } \\
\text { Sand }\end{array}$ & $\begin{array}{l}\text { Measured } \\
\text { Limestone }\end{array}$ \\
\hline Wbe & 0.008133 & 0.009113 & 0.007532 & 0.011867 & 0.037349 \\
\hline $\mathrm{Wb}$ & 0.020041 & 0.021022 & 0.019440 & 0.023775 & 0.049257 \\
\hline Vba & 0.011675 & 0.011675 & 0.011675 & 0.011675 & 0.011675 \\
\hline Vbe & 0.007974 & 0.008935 & 0.007384 & 0.011634 & 0.036617 \\
\hline $\mathrm{Vb}$ & 0.019648 & 0.020609 & 0.019059 & 0.023309 & 0.048291 \\
\hline $\mathrm{Wm}$ & 1.020041 & 1.021022 & 1.019440 & 1.023775 & 1.049257 \\
\hline $\mathrm{Pb}$ & $2.0 \%$ & $2.1 \%$ & $1.9 \%$ & $2.3 \%$ & $4.7 \%$ \\
\hline Pbe & $0.8 \%$ & $0.9 \%$ & $0.7 \%$ & $1.2 \%$ & $3.6 \%$ \\
\hline Vsb & 0.376506 & 0.376506 & 0.376506 & 0.376506 & 0.376506 \\
\hline Vmm & 0.384480 & 0.385441 & 0.383890 & 0.388140 & 0.413123 \\
\hline Vmb & 0.400500 & 0.401501 & 0.399886 & 0.404313 & 0.430336 \\
\hline VMA & $6.0 \%$ & $6.2 \%$ & $5.8 \%$ & $6.9 \%$ & $12.5 \%$ \\
\hline$D / B$ & 0.20 & 0.23 & 0.19 & 0.30 & 0.91 \\
\hline VFA & $33 \%$ & $36 \%$ & $32 \%$ & $42 \%$ & $68 \%$ \\
\hline$\%$ Vbe & $2 \%$ & $2 \%$ & $2 \%$ & $3 \%$ & $9 \%$ \\
\hline$\% \mathrm{Vb}$ & $5 \%$ & $5 \%$ & $5 \%$ & $6 \%$ & $11 \%$ \\
\hline
\end{tabular}

